Nimuendajú Was Right: The Inclusion of the Jabutí Language Family in the Macro-Jê Stock Author(s): Eduardo Rivail Ribeiro and Hein van der Voort

Reviewed work(s):

Source: International Journal of American Linguistics, Vol. 76, No. 4, This issue edited by Ana Vilacy Galucio and Spike Gildea. (October 2010), pp. 517-570

Published by: The University of Chicago Press

Stable URL: http://www.jstor.org/stable/10.1086/658056

Accessed: $13 / 07 / 2012$ 08:59

Your use of the JSTOR archive indicates your acceptance of the Terms \& Conditions of Use, available at http://www.jstor.org/page/info/about/policies/terms.jsp

JSTOR is a not-for-profit service that helps scholars, researchers, and students discover, use, and build upon a wide range of content in a trusted digital archive. We use information technology and tools to increase productivity and facilitate new forms of scholarship. For more information about JSTOR, please contact support@jstor.org. 


\title{
NIMUENDAJÚ WAS RIGHT: THE INCLUSION OF THE JABUTÍ LANGUAGE FAMILY IN THE MACRO-JÊ STOCK ${ }^{1}$
}

\author{
EduARdo Rivail Ribeiro \\ Museu Antropológico, Goiânia \\ UNIVERSITY OF CHICAGO
}

\author{
HEIN VAN DER VOORT \\ RAdBoud UNIVERSITEIT NIJMEgEN \\ Museu Paraense Emílio Goeldi
}

\begin{abstract}
So far, the available data on the Arikapú and Djeoromitxí languages of the Brazilian Amazon, which together form the Jabutí language family, have been too sparse to enable one to evaluate existing proposals for a genealogical classification. Recent descriptive fieldwork, however, has yielded information that strongly corroborates an early hypothesis of Nimuendajú (2000 [1935]) that the languages are related to those of the Jê family. In this article, we compare the reconstructed ancestors of both families, Proto-Jabutí (van der Voort 2007) and Proto-Jê (Ribeiro [forthcoming]), ultimately demonstrating that Nimuendajú was right. We also discuss some of the consequences of this discovery for
\end{abstract}

\footnotetext{
${ }^{1}$ The Arikapú and Djeoromitxí data in this article are from the fieldwork of Hein van der Voort and the data on other Macro-Jê languages are from the fieldwork of Eduardo Ribeiro, unless indicated otherwise. We want to thank our teachers and consultants Nazaré Arikapú, the late Mamoa Arikapú, Raimundo Jabutí, André, Armando, and José Roberto Jabutí, and José Purité Arikapú (Arikapú and Djeoromitxí); the late Ijeseberi Karajá, Sinvaldo Wahuka, and Luís Kurikala (Karajá); and Ataíde Xehitãã, Marilda Xahtâ, and José Koy (Ofayé). We are gratefully indebted to Denny Moore for his encouragement and ideas. We also gratefully acknowledge the beautiful map tailormade by Willem Doelman. We thank the University of Oregon at Eugene, the Universidade Federal do Pará at Belém, and the Netherlands Organisation for Scientific Research (NWO), who provided infrastructure and opportunities for collaboration through NWO internationalization grant no. 235-70-002 "Exploring the Linguistic Past: Historical Linguistics in South America." Eduardo Ribeiro would like to thank the members of the research group "Estudos Histórico-Comparativos Macro-Jê" at the Museu Antropológico (Universidade Federal de Goiás), particularly Christiane de Oliveira and Marília Ferreira, for sharing their knowledge of Apinajé and Parkatêjê, respectively. We also want to thank Spike Gildea, José Pedro Viegas Barros, and two anonymous reviewers for their constructive comments. Ribeiro is furthermore especially thankful to Luciana Dourado, for providing him with data of (and clarifications on) Panará, and to Lucy Seki, for valuable insights on Krenák. Ribeiro's research on Ofayé was undertaken under the auspices of the Endangered Languages Documentation Project (SOAS, London), whose support he gratefully acknowledges. Hein van der Voort wants to thank Sebastian Drude, Vilacy Galucio, Gale Goodwin Gómez, and Gessiane Picanço for their important comments and Sérgio Meira for teaching him about historical reconstruction. Furthermore, he gratefully acknowledges the support of the Netherlands Foundation for the Advancement of Tropical Research (WOTRO), who financed the entire Arikapú descriptive project under grant no. W 39-273, and the Netherlands Organisation for Scientific Research (NWO), who financed the Jabutí comparative research grant no. 276-70-005. Notwithstanding our indebtedness, the responsibility for the contents of this article rests solely with us.
}

[IJAL, vol. 76, no. 4, October 2010, pp. 517-70]

(C) 2010 by The University of Chicago. All rights reserved.

0020-7071/2010/7604-0005\$10.00 
current ideas about prehistoric population movements in lowland South America.

[Keywords: Arikapú, Djeoromitxí, Jabutí family, Macro-Jê stock, Amazonian languages]

1. Introduction. Arikapú and Djeoromitxí are two Brazilian Amazonian languages that together compose the Jabutí language family. Both languages are traditionally spoken on the Rio Branco, a right tributary of the Guapore River that separates the northeastern Bolivian province of Beni from the western Brazilian state of Rondônia. Although these languages used to be native to traditional rainforest populations of considerable size until about a century ago, the (estimated) number of Djeoromitxí speakers has now dwindled to a mere 50, and Arikapú is on the verge of extinction with only one elderly speaker. The total number of persons that identify ethnically with Arikapú or Djeoromitxí is somewhat bigger.

Until recently, the Jabutí languages were practically undocumented. Nevertheless, claims have been raised about their classification. On the basis of 100 words, Rivet (1953) classified one of the Jabutí languages as a Chibcha language. Loukotka $(1963 ; 1968)$ grouped the Jabutí languages together as a small isolated family on the basis of short comparative word lists. Nimuendajú (2000 [1935]) and Greenberg (1987) classified the languages as belonging to the Macro-Jê stock on the basis of even smaller word lists. ${ }^{2}$

In this article we provide sound evidence, on the basis of extensive and reliable new data from all language components, for the classification of the Jabutí languages as belonging to the Macro-Jê language stock. To this end, we first present the general characteristics of both families and their respective proto-languages ( $\mathbf{2}$ and $\mathbf{3}$ ). Then we show correspondences between Proto-Jabutí and Proto-Jê (4). Finally, we discuss some possible consequences of such a remote westerly location of a Macro-Jê family for current ideas about the original dispersion center of the Macro-Jê-speaking tribes. The Swadesh basic 100-word list for Arikapú and Djeoromitxí is provided in Appendix A, together with reconstructed proto-forms.

\footnotetext{
${ }^{2}$ As those who are familiar with South American linguistic historiography will know, Nimuendajú was careful not to make claims of linguistic connections (genetic or otherwise) without enough evidence (as illustrated by his debate with Mansur Guérios, published as Nimuendajú and Guérios 1948). The evidence he mentions, included in a personal letter (and not as a paper for publication), is indeed very little, but it is likely that he had detected many more similarities. His comparison includes items from the Kamakã and Kotoxó languages (both belonging to the Kamakã family, which had traditionally been considered as closely related to Jê since von Martius's [1867] classification), in addition to languages now included in the Jê family. The fact that Nimuendajú, in his latest classification (IBGE 1981 [1944]), excludes from Jê all the traditional eastern Macro-Jê families (such as Kamakã) while maintaining the Jabutí languages is in itself symptomatic of his degree of certainty that this family should be included.
} 
2. The Jabutí languages. In this section, we present a sketch of the sociolinguistic (2.1) and historical (2.2) contexts of Arikapú and Djeoromitxí and give a basic typological, phonological, and grammatical characterization of the languages (2.3) and their ancestor Proto-Jabutí (2.4), as reconstructed by van der Voort (2007).

2.1. Sociolinguistic setting. Traditionally, the Jabutí languages were spoken in close proximity to one another, to the Tuparí languages (Tupí family), and possibly also to Chapakura languages and isolated (or unclassified) languages. The steep demographic decline after the onset of regular contact with Western society has been characteristic of most native peoples in the Guaporé region. Today, Rondônia represents one of the most deforested regions of the Amazon and the decimated indigenous groups live scattered over different indigenous reserves, agricultural boomtowns, and city slums. The great majority of its 25 indigenous languages have fewer than 50 speakers.

Nowadays, the majority of the Djeoromitxí and one speaker of Arikapú live in the Guaporé indigenous reserve. This reserve, formerly called Ricardo Franco, was established in the 1930s to harbor the remnants of indigenous groups of southern Rondônia-individuals or groups that had escaped from slavery on rubber plantations and other Western extractivist enterprises or that had become dispossessed by invasions or by the effects of governmental policies of land distribution. The reserve is located on the Guapore River itself and is only accessible by boat or by aircraft. Although the river represents the border with Bolivia and the indigenous inhabitants could not have been pushed off the map of Brazil any further, its remote location provides at least some chance for cultural survival. Presently, approximately 500 individuals from ten different ethnic backgrounds inhabit the reserve. Portuguese is the main lingua franca. The minority languages Djeoromitxí and Makuráp (Tuparí branch of Tupí) are spoken by all generations. There is also a family of Tuparí (Tuparí) speakers and there are several, mostly elderly, speakers of Aruá (Mondé branch of Tupí), Wayurú (Tuparí), Kuyubí and Wari' (both Chapakura), and Aikanã and Kanoê (both isolates) The ethnic Arikapú either have Djeoromitxí or Makuráp as a first language.

Another speaker of Arikapú passed away in 2009. He and the remaining speakers of Djeoromitxí lived closer to their traditional lands in the Rio Branco indigenous reserve, which was demarcated in the 1980s and covers part of the traditional habitat of the Makuráp and Djeoromitxí. As a reserve, this area is governmental property and by the Brazilian constitution only the indigenous inhabitants enjoy usufructuary rights of the forest and the rivers that run through it, of which the Rio Branco is the principal one. Unfortunately, the headwaters of the Rio Branco, which form the traditional habitat of the Djeoromitxí, Arikapú, and Tuparí, were left outside of the demarcated area. Every year more and more of the region is deforested and the rivers are 
blocked or diverted for hydroelectric plants. This damages the hydrological and ichthyologic balance of the reserve and contributes to rising levels of agro-toxins. ${ }^{3}$ The integrity of the reserve is further threatened by invading Western loggers, poachers, and illegal fishermen. At this moment, approximately 400 persons from six different ethnic backgrounds inhabit the reserve. Tuparí (Tuparí) is the dominant language in most settlements, while Makuráp (Tuparí) is spoken by a minority. Djeoromitxí and Aruá (Mondé) are spoken by several, mostly elderly, persons. There is a group that identifies itself as Kampé but does not speak the traditional language (which seems to be a Tuparí language). The ethnic Arikapú who live in the Rio Branco reserve all have Tuparí as a first language. Many inhabitants of the reserve also speak Portuguese.

Even though the number of speakers of Djeoromitxí is low, it is a living language in several settlements within the Guaporé reserve. The Arikapú language went out of use years ago and may show phenomena of obsolescence.

2.2. History of research. The first documentation ever of a Jabutí language is the word list from 1914 by the English colonel Percy Harrison Fawcett, who in the early twentieth century led several expeditions to survey the Bolivian-Brazilian frontier. Fawcett recorded a list of about 100 words on one of the eastern tributaries of the upper Rio Branco and refers to the speakers of the language as Mashubi (1915; 1953; see also Rivet 1953). ${ }^{4}$ Fawcett estimated that the population numbered about 2,000 individuals, divided over 24 villages. Since Fawcett, no one has ever again met a group called Mashubi. Therefore, the Mashubi language is considered in most of the literature (Loukotka 1963; 1968, Campbell 1997, and Dixon and Aikhenvald 1999) as an extinct language, related to Arikapú and Djeoromitxí. However, the Swiss ethnographer Franz Caspar, who lived with the Tuparí for many months in 1948 and 1954-55, and who also documented the languages of their Arikapú and Djeoromitxí neighbors, claims that Mashubi is probably a variety of Arikapú (Caspar 1955a; 1955b). This is confirmed by evidence from the field (van der Voort 2005; forthcoming $a$ ). Hence, the Jabutí languages are considered in this article as forming a small family with only two

\footnotetext{
${ }^{3}$ In addition, the construction of hydroelectric dams are a danger to archaeological remains that represent evidence of traditional indigenous habitation. At the construction site of a nearby new house in 2004, funerary urns were unearthed and destroyed. Among these urns were possibly those in which our consultant, Nazaré Arikapú, had buried her mother and her first child. Brazilian law considers indigenous funerary remains as evidence in matters of land rights. No decisive action was taken by the authorities, however.

${ }^{4}$ During this trip, Fawcett met the Swedish ethnographer Erland Nordenskiöld, who was heading for the Huari (Aikanã) (Nordenskiöld 1915). Somehow Nordenskiöld obtained a copy of Fawcett's word list and eventually passed it on to the French linguist Paul Rivet, who published it in 1953, trying to relate the language to Chibcha.
} 
members: Arikapú and Djeoromitxí; and the earliest documentation of Arikapú is that by Fawcett (in Rivet 1953).

The next phase in documentation occurred when the German ethnographer Emil Heinrich Snethlage visited the Guaporé region in 1933-34 (Snethlage 1937). Snethlage met many peoples of the Rio Branco, including the Arikapú and Djeoromitxí (whom he also called Kipiu), and returned to Berlin with a collection of objects, photographs, film, and music recordings on wax rolls (Snethlage 1939). Unfortunately, his early death (see R. Snethlage 2002) prevented him from publishing about his experiences and data to a fuller extent. Snethlage had been in contact with the famous Curt Nimuendajú, who during his life visited over a 100 indigenous peoples and published widely on their languages, cultures, and mythology during the first half of the twentieth century. Snethlage provided him with short word lists of Arikapú and Djeoromitxí. Nimuendajú noticed a striking resemblance to words in Jê languages such as Xerénte, Kayapó, Kaingáng, and Timbíra. He hypothesized that both languages compose a branch of the Jê language family, which he mentioned in 1935 in a letter to his colleague Carlos Estevão de Oliveira (Nimuendajú 2000:219-22). Also, he represented them as such on a manuscript map (Nimuendajú 2000:10, figure 7), ${ }^{5}$ and on his classificatory map, which was eventually published in 1981 (IBGE 1981). The very fact that Greenberg (1987) adopted this classification may have been a reason that it did not become broadly accepted among Americanists.

As mentioned above, Franz Caspar lived in the Rio Branco region between 1948 and 1955 and is known especially for his popular and scientific accounts of traditional Tuparí culture (1952; 1975). Caspar also collected extensive word lists of all the languages he encountered, including Djeoromitxí and Arikapú. He had access to Snethlage's diaries and cited from them in his doctoral dissertation (Caspar 1953). The Czech linguist Loukotka had access to word lists by Snethlage and published a comparative account of them, grouping Arikapú and Djeoromitxí together with Mashubi as an isolated language family (Loukotka 1963). Fortunately, some of Snethlage's and most of Caspar's unpublished material from the Guaporé region is now becoming available online (Brijnen and Adelaar 2010). ${ }^{6}$

\footnotetext{
${ }^{5}$ According to the editor of this collection of letters, the manuscript map, which shows the geographic distribution of the Jê languages including the small western island of "Arikapú \& Jabotí," was included in a letter of 20 July 1934. It is likely, however, that it rather belonged to another letter, such as the next one from 22 January 1935, in which the Jê hypothesis was first mentioned. Furthermore, Snethlage did not leave the field before the end of November 1934 and probably showed his linguistic material to Nimuendajú first around the end of December in Belém.

${ }^{6}$ As the result of an important digitalization initiative (2010) by Willem Adelaar and Hélène Brijnen of Leiden University, all of Caspar's known unpublished linguistic data, as well as those of the nineteenth-century explorer Johann Natterer, and some of Snethlage's and Sekelj's, are being made available in the Digital Humanities section on the website of the Leiden University Library.
} 
Traditionally, the indigenous peoples of the region must have had several thousand members each. Because of the absence of resistance against the infectious diseases of the Old World, more than half of the population of a group may die upon first contact with Westerners, if no protective action is taken. When Snethlage met the Arikapú, they were already a small group, divided over two settlements. In 1948, just before Caspar arrived in the region for the first time, the Yugoslavian journalist Tibor Sekelj traveled up the Rio Branco in order to visit the Tuparí. In his popular account, he mentions the neighboring groups as well and refers to the Arikapú as "the world's smallest nation" (Sekelj 1950). In early 1954, the Indians of the Rio Branco suffered another horrible measles epidemic. The Arikapú were apparently hit very hard and when Caspar returned in 1954, they had dwindled to one small group. In 1968, the linguists Willem Bontkes (1968) and Robert Campbell surveyed the south of Rondônia for the evangelical Summer Institute of Linguistics. Bontkes recorded a short Arikapú word list at Rio Branco and mentioned the existence of 14 speakers. Campbell (1968) recorded a word list of Djeoromitxí there, from which some items were published in Rodrigues (1986).

In the 1980s, several anthropologists and linguists visited the region and met speakers of Jabutí languages. In her article, the ethno-historian Denise Maldi described southeastern Rondônia as a cultural area, called the Marico cultural complex, that includes Tupí groups, groups speaking isolated languages, and the Arikapú and Djeoromitxí (Maldi 1991). Her survey includes small word lists and traditional myths. Furthermore, the linguist Denny Moore of the Museu Goeldi collected comparative word lists in the Guaporé indigenous reserve, including Arikapú and Djeoromitxí (Moore 1988). Subsequently, the linguistics student Nádia Pires did fieldwork among the Djeoromitxí on the Guaporé reserve for her master's thesis, which resulted in a concise description of Djeoromitxí (1992) and literacy material for the native language (Pires, Jabuti, and Jabuti 1994; 1995). The section on Jabutí in Dixon and Aikhenvald's survey (1999:357-58) is based on the work by Pires. Between 2001 and 2004, Hein van der Voort conducted fieldwork with two known speakers of Arikapú and is preparing a description of the language (van der Voort [forthcoming $b$ ]). Certain lexical similarities between Jabutí languages and other languages of the region are mentioned in van der Voort (2005). In 2008, the linguistics student Thiago Vital conducted fieldwork in the Guaporé reserve and documented Djeoromitxí oral history and traditions on a series of DVDs and CDs. In the same year, linguistics students in Guajará-Mirim wrote dictionaries of Arikapú and Djeoromitxí, based on interviews with visiting native speakers, for their master's theses (R. Ribeiro 2008 and M. Ribeiro 2008). In spite of these recent initiatives by linguists, we must emphasize that the documentation and analysis of both Arikapú and Djeoromitxí are still in an initial stage. 
2.3. Characteristics of Jabutí languages. The Jabutí languages are genetically unrelated to the other languages and language families of the Guaporé region and present a number of unique features, both in their phonology and grammar (for comparative work on these languages, see van der Voort 2005; 2007). They are highly isolating languages, they have some phonological traits that are unusual in the region, and their lexicon is markedly different from that of the others. Nevertheless, they also share a number of characteristics with other languages, probably as the result of diffusion, especially with regard to the lexicon. Many loanwords are from Makuráp, which has functioned as a lingua franca for some time during the twentieth century (Caspar 1975:223, Sekelj 1950:50, and Snethlage 1937:127ff.).

When compared to each other, the Jabutí languages are highly similar. Since Arikapú and Djeoromitxí used to be closely neighboring languages, it is likely that they have diversified from a common ancestor in the same region. It seems less likely that they diversified somewhere outside of the region and at a certain moment immigrated together. This implies that the time depth between Arikapú and Djeoromitxí indicates the minimal length of time that the Jabutí languages exist in the Guaporé region. In the following subsections, we describe the basic characteristics of the Jabutí languages.

2.3.1 Arikapú. One important difficulty for the study of Arikapú is that the language has been out of use for a long time and the speakers who were recorded did not produce narrative texts or fluent dialogues. In principle, one cannot claim with absolute certainty that the syntactic patterns encountered in the recordings are original rather than the result of influence by more current languages, such as Djeoromitxí, Makuráp, Tuparí, or Portuguese. Also, certain morphological properties of the language may have become obsolete. Although the fluency of the remaining speakers was difficult to assess, one nevertheless gets the impression that the different speech samples they produced are consistent and highly similar in structure. In this respect, it is important to remember that the two remaining speakers lived far apart and did not maintain any contact with each other. Now, there is only one speaker of Arikapú left.

2.3.1.1. Phonology. According to recent analyses (van der Voort [forthcoming $b]$ ), the phonological system of Arikapú comprises eight oral vowels and six nasal vowels. The consonant system includes ten phonemes (see table 1).

Although Arikapú has a number of nasal vowels, which are confirmed by minimal pairs such as nĩkra 'hips' vs. nĩkrã 'wrist', takə 'it is hot' vs. tak̃ 'it is finished', tari 'to clear the field' vs. tari 'it is dry', and $k u$ 'to eat' vs. $k \tilde{u}$ 'to leave', there is also some variation between nasal and oral pronunciation of vowels, and spread of nasality to neighboring (usually left) syllables. Hence there is limited evidence for a nasal phoneme /õ/, whereas most occurrences of the nasal phoneme $/ \tilde{\varepsilon} /$ seem to be the result of nasal 
TABLE 1

ARIKAPÚ VOWEL PHONEMES

\begin{tabular}{|c|c|c|c|c|c|c|}
\hline & \multicolumn{3}{|c|}{ Pral Vowels } & \multicolumn{3}{|c|}{ Nasal Vowels } \\
\hline & Front & Central & Back & Front & Central & Back \\
\hline Close & $i$ & $\bar{i}$ & $u$ & $\tilde{l}$ & & $\tilde{u}$ \\
\hline Close-mid & $I$ & $\partial$ & & & $\tilde{\partial}$ & \\
\hline Open-mid & $\varepsilon$ & & $o[\circ]$ & $\tilde{\varepsilon}$ & & $\tilde{o}[\tilde{\partial}]$ \\
\hline Open & & $a[\mathrm{a}]$ & & & $a[\tilde{\mathrm{a}}]$ & \\
\hline
\end{tabular}

TABLE 2

Arikapú Consonant Phonemes

\begin{tabular}{lcccc}
\hline \hline & Labial & Alveolar & Velar & Glottal \\
\hline Plosive & $p$ & $t$ & $k$ & \\
Nasal & $m$ & $n$ & & \\
Trill/tap & & $r$ & & \\
Fricative & & & & $h$ \\
Affricate & & $t f$ & & \\
Approximant & $w$ & $j$ & & \\
\hline
\end{tabular}

spreading, except in two homophonous lexical roots, $r \tilde{\varepsilon}$ 'egg' and 'dance', which contrast minimally with $r \varepsilon$ 'cord, grub'. (For a likely diachronic explanation of this exception, see 4.1.1.)

The language also has diphthongs, some of which contrast with combinations of multiple vowels that belong to different syllables, as in kaj 'head' vs. $k a . i$ 'hair, fur, feathers'. Stress is placed on the ultimate syllable of the word. The /j/ occurs also in onset position, in words like mujo 'long club', kuju 'wing, feather', rajo 'uncle'. Furthermore, there are some cases of $/ \mathrm{j} /$-insertion in stressed syllables in certain words, such as kam̃̃ 'hill' vs. kamz̃jtfutf $\varepsilon$

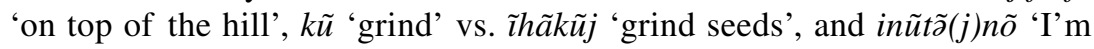
sleeping' (see table 2).

Arikapú has some very frequent consonant combinations, such as $/ \mathrm{pr}, \mathrm{kr}$, $\mathrm{mr} /$, although their distribution is somewhat limited. Less common consonant combinations are /pw, kw, mw, pj, nj, wr, rn/.

There are some frequently occurring consonant alternations in Arikapú. The most common one concerns $/ \mathrm{m} /$, whose allophones [b] and [mb] occur in free variation with each other, before oral vowels, as in /miku/ [biku] [mbiku] 'yard'; /mo/ [bu] [mbv] 'arrow'. Word-internally, the preceding vowel is often nasalized, as in /kamu/ [kã'bu] [kam'bu] 'young one'; /kra- 
mrə/ [krã'brə] [kra'mbrə] 'beads' (lit., 'stone-little') (['] indicates stress placement).

A similar pattern concerns the $/ \mathrm{n} /$, which has the freely alternating allophones [d] and [nd] before oral vowels and which, word-internally, causes

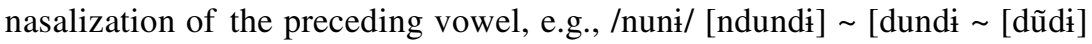
'breast'.

Note that $/ \mathrm{m} /$ and $/ \mathrm{n} /$ also have nasal allophones, $[\mathrm{m}]$ and $[\mathrm{n}]$, respectively. These allophones occur mostly preceding nasal vowels and are in complementary distribution with $[\mathrm{b} / \mathrm{mb}]$ and $[\mathrm{d} / \mathrm{nd}]$. Counterexamples to this complementarity usually involve loanwords. There are a few rare counterexamples in which $[\mathrm{m}]$ is attested preceding an oral vowel, but there always seems to be free variation between that oral vowel and its nasal counterpart, and no minimal pairs are attested.

The [d3] should probably not be considered as a separate phoneme, since its distribution is limited to preceding an [i] and does not contrast with [d] in that position. Although the [n] is also attested preceding an [i], that [i] appears to be in free variation with nasalized [ĩ] in the same position. Therefore, all three should be regarded as allophones of $/ \mathrm{n} /$.

There is some phoneme fluctuation between $/ \mathrm{t} / \mathrm{a} d \mathrm{a} / \mathrm{h} /$. These phonemes occur in free variation only in certain lexemes: tfaroko haroko 'talk, say, language'. This alternation probably represents a relic of a similar, still productive alternation in Djeoromitxí between /r/ and /h/ (see 4.2.1 below). There is variation between the presence and absence of $/ \mathrm{t} / \mathrm{in}$ a number of lexemes, such as $i \sim t f i$ 'bone' and paa p ptfa 'to form, shape, knit'.

The glottal stop is probably not a phoneme but an automatic phenomenon that is motivated by a tendency to preserve the basic syllable structure CV.

Note that in the speech of one of our consultants, the $/ \mathrm{k} /$ is often aspirated [kh] when it precedes back rounded and central vowels. This is probably due to interference from Djeoromitxí.

2.3.1.2. Grammar. From the available data it appears that the Jabutí languages are grammatically similar. They are relatively isolating languages. The basic parts of speech are nouns, verbs, adverbs, and particles. Adjectives are not distinguishable from uninflected intransitive verbs. Basic constituent orders are noun-modifier and SOV or OVS, which are often given as interchangeable optional alternatives by the consultants. There are a number of obligatory prefixes for person marking, the majority of which are distributed according to an ergative pattern. There is no case marking of core arguments, but there is a handful of postpositions that mark the semantic function of

\footnotetext{
${ }^{7}$ In the case of $i \sim t f i$ 'bone', it is worth mentioning that the consonant-initial form occurs only as the second element in compounds, or preceded by a prefix. It is likely that, in such cases, the basic form is $i$, and that $\left[\mathrm{t} \int\right]$ developed originally as transition glide.
} 
TABLE 3

ARIKAPÚ PERSON MARKING

\begin{tabular}{|c|c|c|c|c|c|c|}
\hline & \multirow[b]{2}{*}{ Pronouns } & \multirow[b]{2}{*}{ Possessive } & \multirow[b]{2}{*}{ Intransitive } & \multicolumn{2}{|c|}{ Transitive } & \multirow{2}{*}{$\begin{array}{c}\text { Declarative } \\
\text { Interrogative } \\
\text { Subject }\end{array}$} \\
\hline & & & & Subject & Object & \\
\hline $1 \mathrm{SG}$ & $i h \varepsilon$ & $i-$ & $i-$ & $i h \varepsilon$ & $i-$ & $=n \tilde{o}$ \\
\hline 2 & $a h \varepsilon$ & $a-$ & $a-$ & $a h \varepsilon$ & $a-$ & $=n \varepsilon$ \\
\hline 3 & - & $i-, t a-, t f i-, N$ & $i-, t a-$ & $N$ & $i_{-}^{-}, t \int i-, t \int \varepsilon^{-}, N$ & - \\
\hline 1PL & tfihe & $t \int i-$ & $t f i-$ & - & $t \int i-$ & $(=n \tilde{o})$ \\
\hline Impersonal & - & $i-, a-, t f i-$ & $i-, t f i-$ & - & $i_{-}, t \int i-, t \int \varepsilon_{-}$ & - \\
\hline
\end{tabular}

oblique arguments. The Arikapú elements for person reference and their attested use are listed in table $3 .^{8}$

The person prefixes can in principle be attached to members of any lexical category, be it a noun, verb, or adverb. When attached to nouns, they have a possessive sense, as in example (1) below, and when attached to verbs, they express a structural argument, as in (2).

\section{(1) $a-k a n \tilde{u}$ \\ 2-hat \\ 'your hat' \\ (2) $t a-w \tilde{\varepsilon} r \tilde{z}$ \\ 3-alone}

'He is by himself'.

When attached to intransitive verbs, the person prefixes indicate the subject. When attached to transitive verbs, the person prefixes indicate the object, as in (3) and (4). This suggests that Arikapú has an ergative person-marking strategy.

\footnotetext{
${ }^{8}$ The following abbreviations are used in this article: $1 \mathrm{~s}=$ first-person subject; $1 \mathrm{sG}=$ first-person singular; $1 \mathrm{PL}=$ first-person plural; $2=$ second person; $3=$ third person; $\mathrm{ADJ}=$ adjectivizer; AIK = Aikanã (isolate); AKU = Akũtsũ (Tuparí); API = Apinajé; $A R I=$ Arikapú; ATR $=$ advanced tongue root $; \mathrm{AVE}=$ aversive $; \mathrm{BOR}=$ Boróro $; \mathrm{COMIT}=$ comitative $; \mathrm{CTFG}=$ centrifugal direction $; \mathrm{DAT}$ = dative; $\mathrm{DJE}=$ Djeoromitxí; $\mathrm{DO}=$ direct object; FUT = future; INTENS = intensifier; $\mathrm{KAI}=$ Kaingáng; KAN $=$ Kanoê (isolate); KRA = Krahô; KRJ = Karajá; KNK = Krenák; KWA = Kwaza (isolate); LOC $=$ locative; LP $=$ linking prefix; MAK $=$ Makuráp (Tuparí); MEK = Mekens (Tuparí); MXX $=$ MaXakalí; $\mathrm{N}=$ noun; $\mathrm{NOM}=$ nominalizer; $\mathrm{OFY}=$ Ofayé PAJê $=$ Proto-Amazonian Jê; p.c. $=$ personal communication; $\mathrm{PJab}=$ Proto-Jabutí; PJê = Proto-Jê; $\mathrm{PL}=$ plural; $\mathrm{POR}=$ Portuguese $;$ POS = possessive; PRK $=$ Parkatêjê; REL $=$ relational (or linking) prefix; RIK $=$ Rikbaktsá; SAL $=$ Salamãi (Mondé); $\mathrm{SG}=$ singular; $\mathrm{sp}=$ species; $\mathrm{SUY}=$ Suyá; TRANS $=$ transitive marker; TUP $=$ Tuparí $(\mathrm{Tu}-$ parí); $\mathrm{v}=$ verb; $\mathrm{XAV}=$ Xavante; $\mathrm{XER}=$ Xerente; $\mathrm{WAY}=$ Wayurú (Tuparí).
} 
(3) $a h \varepsilon=n \varepsilon \quad i$-arã-tã

you $=2 \mathrm{~s} \quad 1 \mathrm{sG} / 3$-see-NEG

'Don't you even look at me!'

(4) $t f i$-koni-wiro

1PL-shoot-FUT

'(He) is going to shoot us'.

The Arikapu third-person intransitive argument prefix $t a$-, which does not occur with transitive predicates, was also attested in possessive constructions. Both in form and function it is conspicuously similar to the coreferential/reflexive possessor ('his own') prefix in other Macro-Jê languages (Rodrigues 1986:55):

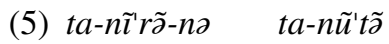

3-place-LOC 3-sleep

'He's sleeping in his own house'.

Arikapú is a "PRO-drop" language, and the use of pronouns and other independent argument nouns is optional. Nevertheless, pronouns occur frequently in the data, usually in subject function. The following alternative phrases show the optionality of pronouns:

(6) $i h \varepsilon=n \tilde{o} \quad i-p i$

$\mathrm{I}=1 \mathrm{~s} \quad 1 \mathrm{sg} / 3$-dead

'I'm drunk'.

(7) $i-p i=n \tilde{o}$

$1 \mathrm{SG} / 3-\mathrm{dead}=1 \mathrm{~s}$

'I'm drunk'.

Apart from pronouns and prefixes, two enclitics are listed in table 3, =nõ and $=n \varepsilon$. These enclitics agree respectively with the first- and the second-person subject of declarative, interrogative, and sometimes imperative sentences. As appears from (7), they may be used simultaneously with person prefixes, but they do not display ergative behavior and they seem to be optional. The most important distributional characteristics of subject clitics are that they tend to be attached to the first syntactic constituent of the sentence; they are never attached to object constituents; and they can be attached to oblique arguments. Note the alternative word orders in the following examples:
(8) $i h \varepsilon=n \tilde{o} \quad t f i-r i h \varepsilon \quad h \tilde{\varepsilon}-w \varepsilon h \varepsilon$
$\mathrm{I}=1 \mathrm{~S} \quad 1 \mathrm{PL}$-food cook-INTENS
'I'm making food'.


(9) $t$ ti-rih $\quad h \tilde{\varepsilon}-w \varepsilon h \varepsilon(=n \tilde{o}) \quad i h \varepsilon$

$1 \mathrm{pl-food}$ cook-intens $=1 \mathrm{~s} \quad \mathrm{I}$

'I'm making food'.

The position of the subject clitic in (9) implies furthermore that the combination of object and predicate forms a syntactic constituent.

2.3.1.3. Nonspecific use of personal prefixes. The prefixes for firstperson singular and plural, $i$ - and $t f i$-, are homophonous with the nonspecific or impersonal prefixes. Because of its ambiguity and its not entirely resolved status, $i$ - is glossed as ' $1 \mathrm{sG} / 3$ '. Because impersonal use of first-person plural is not an uncommon phenomenon across languages, we will continue to gloss $t \int i$ - as '1PL', assuming that it represents the same morpheme. The two prefixes can occur as third-person prefixes that in possessive constructions seem to function often as a dummy possessor and with transitive verbs or semantically adjectival intransitive verbs as a dummy argument. There is a distributional difference between them and the normal person prefixes, which can occur in combination with an overt pronoun. When the possessor or the third-person object is expressed by a full noun, the impersonal prefixes are absent. ${ }^{9}$ The following examples contrast possessive constructions:

(10) $t$ i-praj

1PL-foot

'our foot'

(11) ñ̃wว-praj $\operatorname{ara}=n \tilde{o} \quad(i h \varepsilon)$

tapir-foot see=1s 1

'I saw a tapir track'.

(12) $i$-t fawa

$1 \mathrm{sg} / 3$-flower

'(its) flower', 'my flower'

(13) kukã-tfawa

jambu-flower

'jambu flower'

(12) shows that the absence of a (pro)noun may allow for grammatical ambiguity, since, in principle, various interpretations are possible.

The impersonal prefix $t f i$ - is often interpreted as a plural third person with transitive verbs:

\footnotetext{
${ }^{9}$ It deserves mention here that there are no third-person pronouns in Arikapú.
} 
(14) $i h \varepsilon=n \tilde{o} \quad t / i$-ara

I-1SG 1PL-see

'I saw them'.

On some occasions, there was apparently no pragmatic difference between the prefixes $i$ - and $t j i$, whether in subject function or in object function:

(15) $a h \varepsilon=n \varepsilon \quad i$-kuraj

you $=2 \mathrm{~s} \quad 1 \mathrm{sg} / 3$-throw

'Did you already throw (it) away?'

(16) $a h \varepsilon=n \varepsilon \quad t f i-k u r a j$

you $=2 \mathrm{~s} \quad 1 \mathrm{PL}$-throw

'Did you already throw (it) away?'

The prefix $t f i$ - strongly resembles another prefix, $t \delta \varepsilon$-. It does not occur on intransitive verbs, but it was attested in a possessive function once, and it functions mostly as an unspecified direct object prefix for a transitive verb.

$$
\begin{array}{lllll}
a h \varepsilon=n \varepsilon & \text { pat } f i & t \partial=n \varepsilon, & a-n ə j & t f \hat{\varepsilon} \text {-iro } \\
\text { you }=2 \mathrm{~s} & \text { tobacco } & \text { bring=2s } & \text { 2-older.brother } & \text { DO-want }
\end{array}
$$

'Did you bring tobacco? Your older brother wants some'.

The prefix $i$ - with an impersonal sense resembles the dummy element $i$ or $e$ - in a number of Guaporé languages of different affiliation (see van der Voort 2005). However, it remains a question whether the impersonal prefixes $i$ - and $t f i$ - really should be considered as different prefixes that happen to be homophonous with the first-person singular and plural prefixes $i$ - and $t f i$-. It seems equally likely that they represent impersonal USE of the category first person, similar to impersonal use of the second-person singular or the first-person plural in many other languages.

2.3.1.4. Postpositions. Arikapú has a limited set of elements that indicate the specific semantic function of the oblique arguments they follow. These elements indicate roles such as aversive, dative, instrumental, locative, similative, comitative, and ablative.

(18)

$\begin{array}{llll}i h \varepsilon=n \tilde{o} & i-k o n \tilde{z} & 3 w \tilde{a} w & r i j \\ \mathrm{I}=1 \mathrm{~s} & 1 \mathrm{sG} / 3 \text {-angry } & \text { João } & \text { AVE }\end{array}$

'I am angry with João'.

(19) tfuka ũ i-ri

rope give 1sG/3-DAT

'Give me rope!' 
2.3.1.5. Other grammatical elements. Arikapú has grammatical elements which we have considered as derivational suffixes for the time being, such as nominalizer/adjectivizer - $h \tilde{a}$, diminutive $-m r a j$, augmentative $-t f i t f i$ and $-r u k r \varepsilon$, intensifier $-w \varepsilon h \varepsilon$, negative imperative $-p \dot{t}$, future -wiro, and purposive $-w a$. Note the following example:

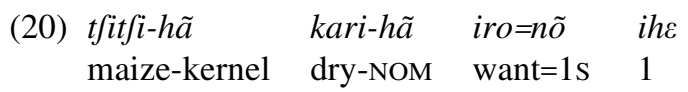

'I want toasted maize'.

In addition, there are elements that resemble nominal classifiers, such as

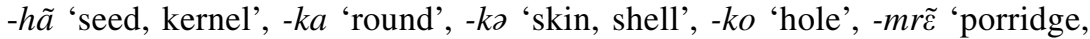

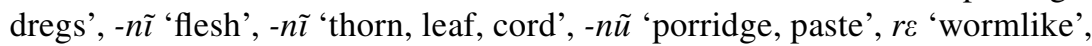
$-r \tilde{\varepsilon}$ 'egg', and -mrə 'powder, flour'. These elements were rarely attested by themselves and were usually preceded by nouns or person prefixes, as in:

(21) $m u r \varepsilon-m r \tilde{\varepsilon}$

manioc-porridge

'manioc porridge'

(22) $a-m r \tilde{\varepsilon}$

2-porridge

'your porridge'

For the expression of their semantic content only, the prefix $i$ - is usually

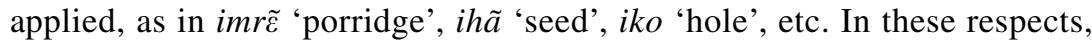
the classifier-like elements strongly resemble those attested elsewhere in the Guaporé region and could be attributed to areal diffusion. Some of the classifying forms even occur in almost identical form in unrelated lan-

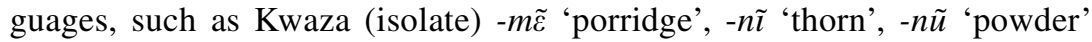
(van der Voort 2005:397). ${ }^{10}$ Since the majority of the classifier-like elements of Arikapú are reconstructible in Proto-Jabutí and Proto-Jê, as will be shown in 2.4.3 and 4.1, their origin is most likely Macro-Jê.

2.3.2. Djeoromitxí. As mentioned in 2.2, Djeoromitxí is a living language that still is transferred to the younger generations. Its speakers are very much in favor of keeping the language alive and actively support its further development in terms of expanding its range of use beyond the traditional context. The literacy project set up by Nádia Pires has been quite successful and Djeoromitxí is used sometimes as a vehicle for teaching in

\footnotetext{
${ }^{10}$ One of the classifiers that is highly productive in the isolated languages of the Corumbiara

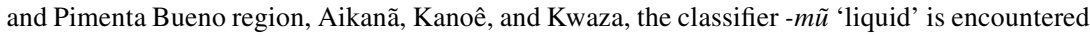
in several river names in use by the Arikapú and Djeoromitxí; that probably means that these hydronyms were borrowed by the Jabutí languages from one (or several) of the other languages.
} 
TABLE 4

DJeoromitxí Vowel Phonemes

\begin{tabular}{lcccccc}
\hline \hline & Front & Central & Back & Front & Central & Back \\
\hline Close & $i$ & $t$ & $u$ & $\tilde{\imath}$ & & \\
$\begin{array}{l}\text { Close-mid } \\
\text { Open-mid }\end{array}$ & $\varepsilon$ & $\partial$ & & & & \\
Open & & $a[\mathrm{a}]$ & $o[0]$ & $\tilde{\varepsilon}$ & & $\tilde{o}[\tilde{\jmath}]$ \\
\hline
\end{tabular}

TABLE 5

DJeOROMITXí ConsonantT PhONEMES

\begin{tabular}{lccccccc}
\hline \hline & \multicolumn{2}{c}{ Labial } & & \multicolumn{2}{c}{ Alveolar } & & \\
\cline { 2 - 3 } & - Voice & + Voice & & - Voice & + Voice & Velar & Glottal \\
\hline Plosive & $p$ & & & $t$ & & $k$ & \\
Nasal & & $m$ & & & $n$ & & \\
Trill/tap & & & & & $r$ & & \\
Fricative & & & & & & & \\
Affricate & $p s$ & $b z$ & & $t f$ & $d 3$ & & \\
Approximant & & $w$ & & & & & \\
\hline
\end{tabular}

primary schools on the reserve. Even modern-style, romantic, guitar-accompanied songs are created and performed in the language. As long as the speakers are allowed to continue as a community, the language will probably survive.

2.3.2.1. Phonology. According to the analyses by Pires (1992), the phonological system of Djeoromitxí comprises seven oral vowels, four nasal vowels, and 14 consonants. In this article, however, we do not consider all of those units as phonemic, and count only 12 consonants $^{11}$ (see table 4 ). The close central rounded vowel $/ \mathfrak{t} /$ is often pronounced as $[\varnothing]$.

There are no diphthongs in Djeoromitxí and combinations of multiple vowels always belong to different syllables. The glottal stop [?] is an optional phonetic phenomenon at the encounter of two vowel phonemes. Stress is placed on the ultimate syllable of the word (see table 5).

Although the available data on Djeoromitxí are less decisive, we assume that the language is essentially like Arikapú in that it does not have a set of

${ }^{11}$ Although Pires's data and analyses are reliable and systematic, they are not complete, and additional data obtained in the field have in certain cases presented us with a different perspective. That is not to say that we consider the analysis put forward here as definitive. Djeoromitxí merits a much more wide-ranging and profound study than has been done so far, especially since there is still a viable speakers' community to make that possible. 
voiced plosive consonant phonemes that are distinct from nasal consonants. The distribution of $[\mathrm{b}]$ and [d] versus [m] and [n] appears to be largely complementary, [b] and [d] occurring basically only before oral vowels, and [m] and $[n]$ before either nasal or oral vowels. ${ }^{12}$

The affricate /bz/ occurs only in one specific environment, before a close front vowel /i/ (see n. 16 for a historical explanation). It nevertheless contrasts with $/ \mathrm{m} /$. The vowel that follows $/ \mathrm{bz} /$ is often not pronounced, as in

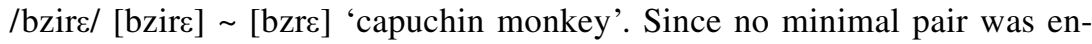
countered, the phonemic status of /ps/ is less obvious, although it contrasts with $/ \mathrm{p} /$ in the same environment.

The $/ \mathrm{d}_{3} /$ is a phoneme that does not occur before /a/ and /a/. In the practical orthography created by the Djeoromitxí and Nádia Pires, it is written as a digraph $\langle\mathrm{dj}>$, similar to the $/ \mathrm{t} f /$, which is written as $\langle\mathrm{tx}>$ (Pires, Jabuti, and Jabuti 1994; 1995).

Note that preceding the close rounded central vowel $[\mathrm{H}]$, the $/ \mathrm{k} /$ is pronounced as [q]. Preceding the central vowel /a/ and the back vowel /u/, it is often aspirated $[\mathrm{kh}]$. Preceding back vowels and $[\mathrm{H}]$, the $/ \mathrm{p} /$ is usually pronounced as a bilabial fricative $[\Phi]$, or as an affricate $[\mathrm{p} \Phi]$.

There is a morphophonological alternation that is characteristic of Djeoromitxí. When /h/-initial words are preceded by a personal prefix, or when they occur as the second element in a composition, the $/ \mathrm{h} /$ is replaced by $/ \mathrm{r} /$. This is shown in the following examples: ${ }^{13}$

(23) ht htmi

I be.ill

'I'm ill'.

(24) ht pa=rtmi

1 foot=be.ill

'My foot hurts'.

(25) hõmeka=rumi

head=be.ill

'I have a headache'.

${ }^{12}$ Partially similar systems were attested in languages of the Tuparí language family, like Makuráp and Mekens (Moore and Galucio 1994), and in a number of Jê languages (Rodrigues 1999). The minimal pair registered in Pires (1992:37) for the opposition between [d] and [n] is not convincing since it contains an unanalyzed phrase <noko $>$ 'to eat' (/nõ ku/, lit., 'eat food') and a loanword from Makuráp: <doko> 'electric eel' (MAK ['nduku], DJE miretfitfi). More research is necessary, however.

${ }^{13}$ Examples such as (24) and (25) are highly productive. Although the theoretical significance of these constructions has not yet been fully explored, they constitute an interesting grammatical parallel with Proto-Jê, where similar noun-verb compounds can be reconstructed. 
TABLE 6

DJEOROMITXí Person MARKING

\begin{tabular}{lccccc}
\hline \hline & & Possessive, & & \multicolumn{2}{c}{ Transitive } \\
\cline { 5 - 6 } & Pronouns & Preposition & Intransitive & Subject & Object \\
\hline 1 SG & $h t$ & - & - & $h t$ & - \\
2 & $a d 3 \varepsilon$ & $a-$ & $a-$ & $a d 3 \varepsilon$ & $a-/ a d 3 \varepsilon$ \\
3 & $n a$ & $i-/ N$ & $i-/ n a / N$ & $n a / N$ & $i-/ N$ \\
$1 \mathrm{PL}$ & $h i r t$ & $h i-$ & $h i-$ & $h i r t$ & $h i-$ \\
Impersonal & - & $h i-$ & - & - & $i-, \varepsilon-$ \\
\hline
\end{tabular}

(26) ham

tired

'He is tired'.

(27) $h_{t}$ hama

I tired

'I'm tired'.

(28) adje a-ramə

you 2-tired

'You're tired'.

Pires (1992:46) contains data that indicate that there is similar morphophonological alternation between $/ \mathrm{h} / \mathrm{and} / \mathrm{n} /$ with certain roots. These alternations remind one of the so-called relational prefixes described for some Macro-Jê and Tupí languages (e.g., Rodrigues 1999 and Seki 2000), as discussed in 3.3 and 4.3. If, as the phonological correspondences seem to suggest (see 4.3), such alternations in Djeoromitxí are indeed related to the ones found in Jê and other Macro-Jê families (Karajá and Ofayé, for instance), this would constitute an important piece of evidence for genetic relationship (a "shared aberrancy").

2.3.2.2. Grammar. The above examples suggest a high degree of similarity between the grammatical structures of Djeoromitxí and Arikapú. As mentioned in the previous section, the basic parts of speech of the Jabutí languages are nouns, verbs, adverbs, and particles, while adjectives ${ }^{14}$ are descriptive intransitive verbs. Basic constituent orders are noun-modifier and SOV or OVS. Djeoromitxí also has obligatory prefixes for person marking, albeit that the forms involved differ from Arikapú. Compare table 3, which shows Arikapú person reference, to table 6, which shows the Djeoromitxí forms and their attested use.

\footnotetext{
${ }^{14}$ As identified by Pires (1992).
} 
In Djeoromitxí, first-person singular is unmarked, whereas the first-person plural and the second-person have obligatory prefixes. The third-person is marked by a prefix when an overt argument or possessor noun is absent. The use of personal pronouns is in principle optional. The following examples show possessive use of the person prefixes:

(29) $n i k t$

field

'my planted field (with maize)'

(30) i-rawa

3-flower

'(its) flower'

Djeoromitxí also has an alternative way to express possession, through the possessive particle d3EwEt $\int a$. This particle can receive person prefixes. Without any prefixes it means 'mine' or 'my':

(31)

$\begin{array}{ll}\text { d3Ewetfa } & \text { tiru } \\ \text { POS } & \text { husband }\end{array}$

'my husband'

(32) a-dzewetfa kau

2-POS neck.hair

'your hair in the back of the neck'

In constructions like these, as well as in other possessive constructions with a possessor noun, the possessed head does not receive person prefixes.

Djeoromitxí has an ergative person-marking strategy. When attached to intransitive verbs, person prefixes indicate the subject; when attached to transitive verbs, person prefixes indicate the object. In the following examples, person marking, or its absence, indicates the subject of the intransitive predicate:

(33) htt haktme

I yawn

'I'm yawning'.

(34) hirt hi-hõrahi

we 1PL-drunk

'We're all drunk'.

With transitive predicates, the object rather than the subject is indicated by person prefixes, the distribution of person marking being ergative in Djeoromitxí. The third person object is marked by the prefix $i$-. 
(35) htt a-ttmi ad3e

I 2-beat you

'I'm going to beat you'.

(36) $h t+i-t \varepsilon \quad a-r i \quad i-\tilde{u} \quad a d z \varepsilon$

I 3-bring 2-DAT 3-give you

'I brought it to give to you'. ${ }^{15}$

Note that Djeoromitxí is not considered as an ergative language in Pires (1992). The behavior of the prefix $i$-is explained as a result of complex word formation. A more recent version of this view is based on the analysis of transitive objects as subjects in passive constructions (Pires 1998). Although this nominative-accusative analysis of Djeoromitxí may also be plausible, it merits further investigation and is not adhered to here.

2.3.2.3. Nonspecific use of person prefixes. Unlike the other person prefixes, the $i$ - prefix does not appear when the argument is represented by an overt noun or pronoun. Like in Arikapú, this prefix often represents a nonspecific or indefinite third-person argument. The difference with Arikapú is that $i$ - is never interpreted as a first person in Djeoromitxí. Note the following examples:

(37)

$\begin{array}{ll}\text { bziru } & \text { kuhi } \\ \text { water spill }\end{array}$

(38) $i$-kuhi-tõ

3-spill-NEG

'Don't spill it!'

Like the Arikapú prefix t $f i-$, the Djeoromitxí prefix $h i$ - can be interpreted both as a first-person plural prefix and as an impersonal prefix. This is probably a cross-linguistically common strategy. Not surprisingly, it is often encountered with human body-part nouns:

(39) hi-məhiri

1PL-lung

'one's lungs'

(40) hi-opad3i

1PL-adam's.apple

'one's Adam's apple'

${ }^{15}$ Constituent order ari iũ adze ht ite was also attested. 
The metaphorical extension of the first-person plural to impersonal is clearest in examples that cannot be so easily interpreted literally, such as (40), which was uttered by a female consultant.

2.3.2.4. Postpositions. Oblique arguments are marked for different roles, such as locative, instrumental, comitative, by a closed set of postpositions:

(41) $i$-hi paka i-pu

3-hair COMIT 3-eat

'(He) eat(s) game with hair and everything'.

(42) niperu tfe a-runã

bench LOC 2-sit

'You sit on the bench'.

Pires (1992) has furthermore documented postpositions such as dative $m a$, agentive $m \varepsilon$, and beneficiary $\varepsilon n i$.

2.3.2.5. Other grammatical elements. Even though the Jabutí languages are relatively isolating, there is some morphology apart from bound person marking. Djeoromitxí has derivational suffixes such as nominalizer - $t f i$, diminutive -titi (Pires 1992), augmentative -t $f i t f i$, and intensifier $-w \varepsilon h \varepsilon$.

Furthermore, there are grammatical elements of which it is hard to say whether they are free particles or bound morphemes, such as negative tõ interrogative $h i$, future $m a$ (probably, the same as the dative postposition), past $t \delta \varepsilon$, and nominalizers $a$, $h \partial$, and $ə$ in Pires (1992). (43) is an example with the adjective nominalizer $h ə$ :

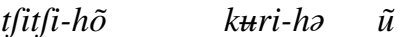
maize-kernel dry-ADJ give
'Give me toasted maize'.

Finally, there are nominal classifiers, such as - $d_{3 \varepsilon}$ 'egg', - $h \tilde{o}$ 'seed, kernel',

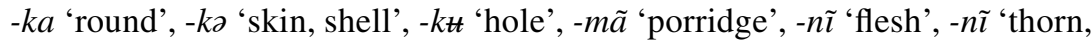
leaf, cord', - $t \partial$ 'small', - $r \varepsilon$ 'wormlike', and - $t u$ 'powder, flour'. Some of these are analyzed by Pires (1992) as the second part of a nominal compound. They were not attested as independent elements. They clearly have derived from nouns, and some of them are still attested as nouns, most of which are obligatorily possessed (with the exception of $k a$ 'skin, shell'). If their semantic content is to be expressed as an independent form at all, these elements minimally require the prefixation of $i$-, as in iho 'kernel', ikt 'hole'. The classifier-like elements of Arikapú and Djeoromitxí constitute highly similar sets of sometimes rather unproductive morphemes that belong to a 
TABLE 7

Proto-Jabutí Vowel Phonemes

\begin{tabular}{lccccccc}
\hline \hline & \multicolumn{3}{c}{ Oral Vowels } & & \multicolumn{3}{c}{ Nasal Vowels } \\
\cline { 2 - 4 } \cline { 6 - 8 } & Front & Central & Back & & Front & Central & Back \\
\hline Close & $i$ & $\dot{t}$ & $u$ & & $\tilde{\imath}$ & $\tilde{t}$ & $\tilde{u}$ \\
Close-mid & $I$ & & & & & & \\
Mid & & $o$ & & & & $\tilde{\delta}$ & \\
Open-mid & & & $o$ & & $\tilde{\varepsilon}$ & & $\tilde{o}$ \\
Open & & $a$ & & & & $\tilde{a}$ & \\
\hline
\end{tabular}

small closed category with a quite limited distribution. To a certain extent their behavior and form resemble those of a number of unrelated languages of the region, which could be explained by areal diffusion. Most of them, however, can be reconstructed for Proto-Jabutí (see 2.4.3) and have lexical cognates in other Macro-Jê families (see 4.1), which suggests that, if areal diffusion of classifiers took place, (Proto-)Jabutí may have been a major source.

2.4. Proto-Jabutí. There is little doubt that Arikapú and Djeoromitxí are genealogically closely related. The similarities on the lexical, phonological, and grammatical levels are very strong and a great number of words can be reconstructed. In this section, we present evidence for the relationship by reconstructing the phonological inventory and a number of lexical and grammatical forms of the proto-language.

2.4.1. The phonological system. The lexical database on which this section is based contains approximately 1,410 unique Arikapú roots and 1,095 unique Djeoromitxí roots. Among these, around 1,085 sets of entries were comparable. After sets that showed no formal similarity whatsoever were excluded, and after probable loans and onomatopoeic forms were separated, roughly 500 sets of entries remained that are possibly cognate. On the basis of the regular correspondences between the phonemes in similar positions in the forms, approximately 200 proto-forms were fully reconstructed, as well as the shared ancestral phonological system. Table 7 shows the reconstructed vowel phonemes of Proto-Jabutí.

In the following lists, regular correspondences between Arikapú and Djeoromitxí phonemes are shown, with their reconstruction in Proto-Jabutí. The numbers correspond to relevant items in the appended Swadesh basic 100-word list. Apart from those items, there are many other fully corresponding cognate sets to support the postulated regular correspondences. The complete list of cognate sets and full information on the conditioning 
environments of the reconstructed phonemes are given in van der Voort (2007).

Proto-Jabutí ArikAPú DJeoromitxí

*a

a

a

a

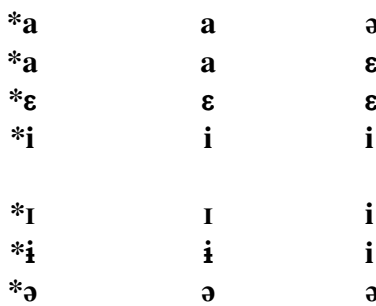

*a

*a

*o

$* \mathbf{u} \quad \mathbf{u}$

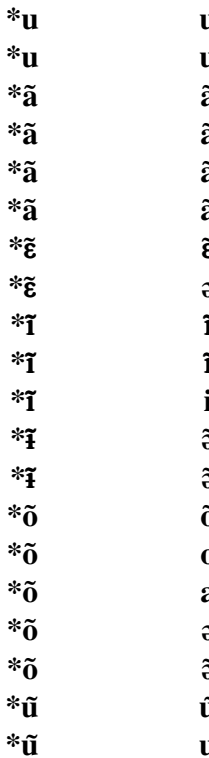

ə, (u)

$\varepsilon$

$\varepsilon$

i

i

i

ə

$\varepsilon$

i

H

u

$\mathbf{u}$

$\mathbf{u}$

ã

$\tilde{\mathbf{a}}$

$\tilde{\mathbf{a}}$

ã

$\tilde{\varepsilon}$

כ

i

$\tilde{\mathbf{1}}$

i

$\tilde{\mathbf{a}}$

$\tilde{\boldsymbol{\partial}}$

о

o

a

כ

$\tilde{\boldsymbol{\partial}}$

$\tilde{\mathbf{u}}$

$\mathbf{u}$ a
$/ \#, t \int r_{-} \quad 57,(99)$

Ij\# 93

44,47

3, 13, 16a, 19, 31, 49, 75, $82,83,92$

$\begin{array}{ll}I m, w_{-} & 85 \\ & 51,75 \mathrm{a}, 88,(96 \mathrm{~b}) \\ / k, m_{-} & 27,28,45,52,53,\end{array}$

58,59

$44,(65), 66,82,83,84,93$

(see van der Voort 2007)

42, 43, 50, 76a, 87, 99

$17 \mathrm{a}, 23,48,55,55 \mathrm{a}, 56$ $73,89,92,96$

$k, n, t f_{-} \quad 51$

$/ m_{-} \quad 89$

$/ m, t_{-} \quad 8,(9)$

Ij\# 67

/_j\# (see van der Voort 2007)

/h, $r_{-} \quad 24,40,57,72$

/m, $r_{-} \quad(33), 47,80$

$/ m r_{-} j \# \quad$ (see van der Voort 2007)

$25,29,79$

$\begin{array}{ll}/ n_{-} & 45,48 \\ / h_{-} & (39), 100\end{array}$

(see van der Voort 2007)

$\begin{array}{ll}/ j \# & \text { (see van der Voort 2007) } \\ / m_{-} & \text {(see van der Voort 2007) }\end{array}$

$/ t, r_{-} \quad 76 \mathrm{a}$

$/ t, r_{-} \quad 100$

$/ t, r_{-} \quad 72$

$/ n, t, r_{-} \quad 8 \mathrm{a}, 60$

/\#, $k, n, r_{-} \quad 19,60,70,87$

$/ k, n, t_{-} \quad 32,96 \mathrm{~b}$

Table 8 shows the reconstructed consonant phonemes of Proto-Jabutí, and below that, lists of regular correspondences and references to items in Appendix A. 
TABLE 8

Proto-Jabutí Consonant Phonemes

\begin{tabular}{lcccc}
\hline \hline & Labial & Alveolar & Velar & Glottal \\
\hline Plosive & $p$ & $t$ & $k$ & \\
Nasal & $m$ & $n$ & & \\
Trill/tap & & $r$ & & \\
Voiceless affricate & & $t f$ & & \\
Voiced affricate & & $d 3$ & & \\
Approximant & $w$ & $j$ & & $h$ \\
\hline
\end{tabular}

\begin{tabular}{|c|c|c|c|c|}
\hline PRoto-JABUtí & ARIKAPÚ & DJEOROMITX & & SWADESH List NuMBER \\
\hline$* \mathbf{h}$ & h & $\mathbf{h}$ & & $24,40,72$ \\
\hline$* \mathbf{h}$ & $\mathbf{t} \int, \emptyset$ & $\mathbf{h}$ & /_i $i$ & 3,100 \\
\hline$* \mathbf{k}$ & $\mathbf{k}$ & $\mathbf{k}$ & & $\begin{array}{l}16,23,27,28,40,42,45, \\
49,52,55 \mathrm{a}, 56,(65), \\
(73), 76 \mathrm{a},(79), 88,96, \\
96 \mathrm{~b}, 98,99\end{array}$ \\
\hline$* \mathbf{m}$ & $\mathbf{m}[\mathbf{b}, \mathbf{m}]$ & $\mathbf{m}[\mathbf{b}, \mathbf{m}]$ & & $\begin{array}{l}8,19,52,53,58,59,62 \mathrm{a}, \\
\quad 79,80,96\end{array}$ \\
\hline$* \mathbf{m}^{16}$ & $\mathbf{m}[\mathbf{b}]$ & bz & /_i & 75,89 \\
\hline$* \mathbf{n}$ & $\mathbf{n}[\mathbf{d}, \mathbf{n}]$ & $\mathbf{n}$ & & $\begin{array}{l}19,25,29,39,44,45,48 \\
51,60,87,96 \mathrm{~b}\end{array}$ \\
\hline$* \mathbf{n}^{17}$ & $\mathbf{n}[\mathbf{d}, \mathbf{n}]$ & $\emptyset,(w)$ & /_e, $\partial, \dot{i}$ & $(51), 96 \mathrm{~b}$ \\
\hline$* \mathbf{p}$ & $\mathbf{p}$ & $\mathbf{p}$ & & $\begin{array}{l}16,19,(39), 46,47,49 \\
\quad(50), 55,66,73,82,83 \\
88,92\end{array}$ \\
\hline$* \mathbf{t}$ & $\mathbf{t}$ & $\mathbf{t}$ & & $\begin{array}{l}8 \mathrm{a},(9), 32,44,45,60,62 \mathrm{a}, \\
\quad 72,100\end{array}$ \\
\hline 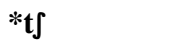 & t $\int$ & t $\int$ & $/ i, \tilde{\imath}, \varepsilon$ & 13,92 \\
\hline
\end{tabular}

\footnotetext{
${ }^{16}$ Under Pires's (1992:20) analysis, /bz/ represents a rare phoneme in Djeoromitxí that occurs only before /i/, where it contrasts with /m/: bzi (ru) 'water' vs. mi 'genipap'. In Arikapú cognates, this contrast does not exist, but there is a contrast between /i/ and /I/ in the same position: $m i$ 'water' vs. $m I$ 'genipap', respectively. Probably, in an earlier phase of Djeoromitxí, [bz] was an allophone of $/ \mathrm{m} /$ conditioned by a high "tense" vowel /i/, whereas the allophone $[\mathrm{m}]$ occurred before the high "lax" vowel /I/. When the contrast between these vowels was lost in Djeoromitxí, /bz/ must have acquired phonemic status. There are only a few complete cognates involving /bz/, e.g., Proto-Jabutí *mihi, ARI mitfi, DJE bzihi pikort 'monkey species' and Proto-Jabutí *tfamuj, ARI tfamuj, DJE habzi 'cotton'.

${ }^{17}$ In some cases, such as * $n \dot{t}$ 'to salt', ${ }^{*} n$ disappeared in Djeoromitxí, changing the word to $i$, whereas it was preserved in Arikapú: $n i$.
} 


\begin{tabular}{|c|c|c|c|c|}
\hline$* \mathbf{t} \int^{18}$ & $\mathrm{t} \int, \mathrm{h}$ & $\mathbf{h}$ & /\#_a, $u$ & 42 \\
\hline$* \mathbf{t} \int^{19}$ & $\mathrm{t} \int, \emptyset$ & $\mathbf{r}$ & $N_{-} a, u$ & $42,43,92$ \\
\hline$* \mathrm{t} \int$ & $\mathbf{k}$ & t $\int$ & /_o & $82,84,93$ \\
\hline$* \mathbf{d}^{20}$ & $\mathbf{t} \int$ & d3 & / $i$ & $16 \mathrm{a}$ \\
\hline *d3 & $\mathrm{t} \int, \emptyset$ & d3 & / $i$ & 31 \\
\hline$* \mathbf{r}$ & $\mathbf{r}$ & $\mathbf{r}, \mathbf{h}$ & & $(65),(67), 76 a, 87,99$ \\
\hline$* \mathbf{r}^{21}$ & $\mathbf{r}$ & $\mathbf{n}$ & / $\tilde{\imath}, \tilde{o}, \tilde{u}, \tilde{a}$ & 57 \\
\hline$* \mathbf{r}^{22}$ & $\mathbf{r}$ & $\emptyset$ & $/ C \_a, i, \tilde{o}, \tilde{a}$ & $46,49,62 \mathrm{a}, 77,83$ \\
\hline
\end{tabular}

The following items suggest that Proto-Jabutí also has glides. The *j usually functions as a semivowel in falling diphthongs. Pires (1992:42-44) notes that there are no diphthongs on the phonological level in Djeoromitxí. ${ }^{23}$ Some examples indicate that the $* j$ was preserved only in Arikapú. Other examples suggest optional /j/-insertion in Arikapú: ${ }^{24}$

$\begin{array}{cccll}\text { Proto-Jabutí } & \text { ARIKAPÚ } & \text { Dieoromitxí } & & \text { SwADESH List Number } \\ * \mathbf{j} & \mathbf{j} & \emptyset & & 8,45,46,(65), 66,67 \\ * \mathbf{j} & \mathbf{j} & \mathbf{i} & / \varepsilon_{-} & \text {(see van der Voort 2007) } \\ *_{\mathbf{w}} & \mathbf{w} & \mathbf{w} & & 85 \\ *_{\mathbf{w}}^{25} & \mathbf{w} & \mathbf{u}, \emptyset & / a, \tilde{o}_{-} & \text {(see van der Voort 2007) }\end{array}$

${ }^{18}$ As shown in 2.3.1.1, Arikapú has a number of lexemes in which /t $\mathrm{j} /$ idiosyncratically alternates with $/ \mathrm{h} /$ and with absence of $/ \mathrm{t} / /$. We showed in 2.3.2.1 how certain lexical roots in Djeoromitxí are subject to morphophonological alternation between $/ \mathrm{r} /$ in onset position word-internally and $/ \mathrm{h} /$ word-initially. These two alternating sets of consonants may be related historically but not synchronically. Be they verbs or nouns, many Djeoromitxí roots that display this morphophonological alternation, such as -rua, hua 'to sing', are cognate with roots in Arikapú that have /t $\mathrm{J} /$ in any corresponding position (i.e., both with or without a preceding prefix or noun), in this case $t \int u a$, reconstructible for Proto-Jabutí as *tfua.

${ }^{19}$ Many Arikapú roots with /t $\int /$, some of which display alternation with [ø], like pəa, pət $\int a$ 'to form, put, weave', are cognate with roots in Djeoromitxí that have nonalternating /r/ (word-internally) or $/ \mathrm{h} /$ (word-initially) in a corresponding position, in this case pera, reconstructible in Proto-Jabutí as *pətfa.

${ }^{20}$ Before /i/, as in Proto-Jabutí *pudzi 'needle', *d3 corresponds to /d3/ in Djeoromitxí, in this case $p u d z i$, Arikapú putfi.

${ }^{21}$ Proto-Jabutí ${ }^{*} r$ underwent a split in Djeoromitxí: before oral vowels it remained as $/ \mathrm{r} /$ and before nasal vowels it changed to $/ \mathrm{n} /$ and merged with Proto-Jabutí $*^{*} n$, as in ${ }^{*} r \tilde{\imath}$ 'braise, grill', DJE $n \tilde{\imath}$, ARI $r \tilde{\imath}$.

${ }^{22}$ Arikapú has a number of consonant combinations with $/ \mathrm{r} /$ in second position in the on-

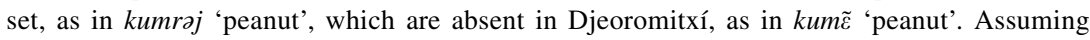
that these consonant combinations underwent simplification in Djeoromitxí, they can be reconstructed for Proto-Jabutí, in this case *kumrẽ j.

${ }^{23}$ In a few cases, [j] was preserved both in Arikapú and in Djeoromitxí, although the cognates correspond only partially or are from possible loanwords: *hãt.j, ARI hãtãj, DJE hõtoi 'slow', and *mejmia, ARI mejmia, DJE meibzia 'tayra'.

${ }^{24}$ See 2.3.1.1. In such cases, reconstructed $* j$ is placed in between brackets.

${ }^{25}$ Few examples exist of $* w$ used as a semivowel, as in *kaw 'hair in the back of the neck'. In this case, Djeoromitxí was simplified or made use of an allophone of $/ \mathrm{u} /$, as in $\mathrm{kau}$, Arikapú kaw. 
A considerable number of lexical and grammatical roots of the Jabutí languages are cognate with roots of Jê languages. These are discussed in $\mathbf{4}$ below and are shown in Appendix A.

2.4.2. The lexicon. Some parts of the lexicon are more suitable than others for the purpose of historical comparison. In the above sections, the highest value is attached to items that represent the most basic concepts that can be expected to be lexicalized in each language, such as body parts, close kinship relations, and geographic phenomena, which can be found in Swadesh's 100 basic word list. It is likely that such items are inherited from previous stages of a language, since they do not tend to represent unknown concepts for which new terms have to be introduced by borrowing or invention.

Although symbolic forms and borrowed forms may show similarities that confirm the same historical correspondences as basic forms do, they are also able to distort the picture and display similarities that are otherwise not accounted for in the specific reconstruction at hand. In the case of the Jabutí languages, there is no clear correspondence between Arikapú /t $\mathrm{f} /$ and Djeoromitxí / $t$ /, for example. The only evidence for this correspondence is a set of items that may be sound-symbolic in origin: Arikapú katfi vs. Djeoromitxí kati 'itch'. In van der Voort (2005:384), a number of possible sound-symbolic forms are listed that are similar to forms in neighboring languages, such as Arikapú kutaj, kokora vs. Djeoromitxí kutfi, krukru 'cicada', which is similar to Aikanã and Kwaza (isolates) $k u k u$, and Arikapú pupu vs. Djeoromitxí popo 'owl', which is similar to Aikanã pupure 'owl species', Kwaza (isolate) Бuбuбudi- '(owl is) calling' and Mekens (Tuparí) popoba 'owl'. Due to their possible onomatopoetic origin, these forms cannot function as evidence for a genetic relationship.

An example that should not be used to confirm reconstruction of *w as a possible semivowel is Arikapú tfaw vs. Djeoromitxí tfãw 'stingray'. These forms are conspicuously similar to Makuráp tfaw, Mekens tfarãw, Kanoê tsãkãwnũ , and Kwaza tsakarũ 'stingray'. In fact, this item may be one of a specific group of lexical items that are found throughout the region. Those items were discussed in van der Voort (2005:385-88) as possible indicators of a linguistic area. The following are also encountered in the Jabutí languages: ${ }^{26}$

ARI and DJE $t$ titfi 'maize': AKU atiti; KAN atiti; KWA atfitfi; MAK atiti; MEK atsitsi; TUP $\alpha$ títi:; WAY atiti:

ARI pãwrũ and DJE mĩoro 'woodpecker': KWA mauru; WAY mã̃urõ ARI $t f u$ and DJE $n u$ 'marico bag': AIK $d y i$; KWA s sui; MAK $\varepsilon t f i$

\footnotetext{
${ }^{26}$ Most forms are from the fieldwork of van der Voort, except for the Mekens forms, which are from Galucio (2001), and some Kanoê forms, which are from Bacelar (2004).
} 


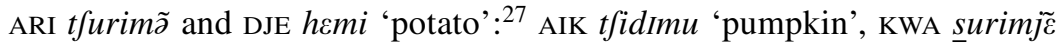
'potato', and SAL zerimũ 'pumpkin'

ARI warəwarz and DJE wirəwirz 'star': Aymara warawara (Willem Adelaar, personal communication); KAN wariwari; KWA waruwaru; MEK waruwaru; TUP and MAK waruwaru

Obviously, none of these forms should be reconstructed to serve as evidence for a genealogical relationship between Arikapú and Djeoromitxí. Then again, even if certain items originate from borrowing or onomatopoeia, they may have been borrowed or created in Proto-Jabutí, before the split between the two Jabutí languages. The value of the reconstruction of such items lies in their confirmation of already independently identified and attested patterns of correspondence.

2.4.3. Grammar. Since it follows from 2.3.1 and 2.3.2 that the grammars of the Jabutí languages are rather similar, it seems reasonable to assume that their shared grammatical traits reflect aspects of the grammar of Proto-Jabutí. In the first place, the person-marking systems are similar. Both languages employ similar person prefixes to express subject or object, according to an ergative alignment pattern. In Proto-Jabutí the forms of two markers may have merged, creating homophony between the first and third person. This ambiguity was preserved in Arikapú, whereas in Djeoromitxí a zeroform emerged representing the first person:

$\begin{array}{cccccc}\text { Person } & \text { Proto-Jabutí } & & \text { ArIKAPÚ } & & \text { DJEOROMitXí } \\ 1 & * i & > & i & \sim & \emptyset \\ 2 & * a & > & a & \sim & a \\ 3 & * i & > & i, \emptyset & \sim & i \\ 1 \mathrm{PL} & * h i & > & t j i & \sim & h i\end{array}$

Also, the nonspecific function of the first-person plural presented in sections 2.3.1.3 and 2.3.2.3 above is a shared trait, although there is also room for a universalist explanation.

Another shared trait is the use of similar, reconstructible, postpositional elements with similar semantic functions, as shown in 2.3.1.4 and 2.3.2.4. Not all attested postpositions were attested in both languages, however, such as Djeoromitxí agentive $m \varepsilon$ and dative $m a$, and Arikapú aversive $r i j$ and similative $r \tilde{z}$ :

\footnotetext{
${ }^{27}$ The claim by van der Voort (2005:388) that the ARI and DJE forms would be cognate is not substantiated by the comparative evidence put forward in this article.
} 


\begin{tabular}{|c|c|c|c|}
\hline FUNCTION & PROTO-JABUTÍ & ARIKAPÚ & DJEOROMITXÍ \\
\hline Ablative & *kunĩ & $-k u n \tilde{\imath}$ & kuni \\
\hline Beneficiary & $(* \varepsilon n \tilde{t})$ & $-n \tilde{\varepsilon}$ & $\varepsilon n i$ \\
\hline Comitative & *pakaj & -pakaj & pako \\
\hline Dative & $*_{r i}$ & $-r i$ & $r i$ \\
\hline Instrumental & $* n a$ & $-n \partial$ & $\partial$ \\
\hline Locative & $* t \int_{\varepsilon}$ & $-t \int \varepsilon$ & $t \int_{\varepsilon}$ \\
\hline
\end{tabular}

Other grammatical elements were discussed in 2.3.1.5 and 2.3.2.5. Some can be reconstructed for the proto-language:

$\begin{array}{llll}\text { Negative } & * t \tilde{o} & t \tilde{\partial} & t \tilde{o} \\ \text { Intensifier } & *-w \varepsilon h \varepsilon & -w \varepsilon h \varepsilon & -w \varepsilon h \varepsilon \\ \text { Augmentative } & *-t f i t f i & -t f i t f i & -t f i t f i\end{array}$

However, a large number of grammatical morphemes cannot be reconstructed. This may involve morphemes that were attested in one of the languages only, such as the Arikapú negative imperative - $p \dot{\boldsymbol{t}}$, or the Djeoromitxí interrogative $h i$ and past $t \int \varepsilon$. Furthermore, some morphemes are very different from one language to the other, such as Arikapú future -wiro and Djeoromitxí future $m a$ (a likely result of the grammaticalization of the dative postposition), Arikapú diminutive - $m r a j$ and Djeoromitxí diminutive -ta or titi, and Arikapú purposive -wə(j) and Djeoromitxí purposive $d z \varepsilon$. Finally, the languages may have influenced one another or may have been influenced by neighboring languages. A case in point is the perfective and adjective nominalizer, Arikapú $h \tilde{a}$ (pronounced as [hã] or [hã]) and the Djeoromitxí adjective nominalizer $h a$, the reconstruction of which is impeded by the absence of systematic vowel correspondence. In Arikapú, however, the morpheme does not seem to be very productive, and its application in certain cases resembles a calque on Djeoromitxí. ${ }^{28}$

Remember that the description of Djeoromitxí is far from complete and that Arikapú is a moribund language. It may be that future research in the field will produce more complete and reliable data, but it is also possible that the languages have lost certain categories over time or due to obsolescence.

As shown in 2.3.1.5 and 2.3.2.5, the Jabutí languages do seem to employ a limited set of classifying elements. Some of them can be reconstructed:

\footnotetext{
${ }^{28}$ Moreover, its form is conspicuously similar to the nominalizer - $h \tilde{\partial}$ of Kwaza (isolate), which may or may not be a coincidence.
} 


\begin{tabular}{|c|c|c|c|}
\hline MEANING & Proto-Jabutí & ARIKAPÚ & DJEOROMITXí \\
\hline seed, kernel & *-hã & $-h \tilde{a}$ & $-h \tilde{o}$ \\
\hline round & $*_{-k a}$ & $-k a$ & $-k a$ \\
\hline skin, bark & $* k \partial$ & $k a$ & $k \partial$ \\
\hline shell & *-kaka & $-k a k \partial$ & $-k a k \partial$ \\
\hline hole & $*_{-k o}$ & $-k o$ & $-k t$ \\
\hline flesh & $*_{-n \tilde{l}}$ & $-n \tilde{\imath}$ & $-n \tilde{\imath}$ \\
\hline thorn & $*_{-n \tilde{l}}$ & $-n \tilde{\imath}$ & $-n \tilde{\imath}$ \\
\hline food, porridge & *nũ & $n \tilde{u}$ & $n \tilde{o}$ \\
\hline wormlike & $*_{-} r \varepsilon$ & $-r \varepsilon$ & $-r \varepsilon$ \\
\hline egg & & $-r \tilde{\varepsilon}$ & $-d 3 \varepsilon$ \\
\hline
\end{tabular}

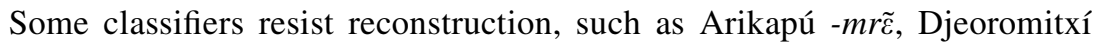
-mã 'porridge, dregs'; Arikapú -mrə, Djeoromitxí -tu 'powder, flour'.

The classifiers also are found fossilized with nouns, as *-ko in *tfako

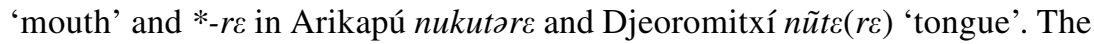
element -kaka 'shell of a nut, seed or animal' itself seems to represent a composite of two classifiers. It is possible that the classifiers originally represented compounded nouns, as analyzed by Pires (1992) for Djeoromitxí. They may have been derived from full nouns and represent an intermediate stage in a grammaticalization process. When looking at the other languages of the region (see van der Voort 2005 and Crevels and van der Voort 2008), several genealogically unrelated languages — such as Nambikwara languages, Tacana languages, and the isolated languages of Rondônia—display similar systems. Some even have similar classifying forms, and it is conspicuous that those forms resemble the Jabutí classifiers that resist reconstruction, such as Kwaza (isolate) - $m \tilde{\varepsilon}$ 'porridge'. Then again, the reconstructed Proto-

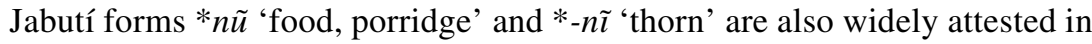
the region, respectively as $-n \tilde{u}$ ' (fine granular matter such as powder, hair, porridge)' in various unrelated languages and as $-n \tilde{\imath}$ 'thorn, needle' in Kwaza. Especially with respect to Proto-Jabutí *-nĩ, likely cognates occur in several Macro-Jê languages, such as Apinajé (Northern Jê) ni, Rikbaktsá $(i-) n i$. This suggests that if the Kwaza and Jabutí forms indeed have the same origin, Jabutí was probably the source.

It is important to be aware of grammatical traits that are similar to those in other languages of the region and that could represent areal features. Either such traits may have been transferred to the Jabutí languages through diffusion from other languages, or the similarity may have been an extra motivation for original Proto-Jabutí traits to be preserved in the Jabutí languages. Alternatively, as will be seen in the following section, some of these grammatical elements are reconstructible for Proto-Jê. Thus, the similarity between 
such elements in the Jabutí languages and unrelated local languages can also point to (Proto-)Jabutí as a source of regional diffusion. ${ }^{29}$

3. The Macro-Jê stock. This section briefly discusses the composition of Macro-Jê, providing a succinct evaluation of the evidence offered thus far as support for the hypothesis of genetic relationship among the several members of the stock (3.1) and a note on their geographic distribution and internal classification (3.2). In addition, we discuss the overall characteristics of the languages included in the stock (3.3), thus setting a background against which the comparison between the Jabutí family and well-established Macro-Jê languages can take place (4). The discussion of the main characteristics of Macro-Jê relies heavily on data from the Jê family, the principal member of the stock, and, for obvious historical reasons, one whose inclusion in it was never questioned. This decision_of comparing Jabutí mainly with Jê, instead of the whole stock-has a number of methodological advantages, the main one being that reconstructions of Proto-Jê, the ancestor of the Jê languages, are available (Davis 1966 and Ribeiro [forthcoming]), providing us with a temporal depth ${ }^{30}$ that is hardly available elsewhere in Macro-Jê (the remaining members of the stock being mostly single-member families; see table 9). Also, a preliminary comparison suggests that Jabutí is not particularly closer genetically to any other families included in the stock, including those that are geographically nearer, such as Boróro, Rikbaktsá, and Chiquitano. Therefore, there is no need for, and probably little gain from, including these languages in the present comparison. In addition, the geographic location of the Jabutí and Jê families (see the map in figure 1) makes it rather unlikely that any similarities detected are due to contact; in fact, no clear cases of shared vocabulary in areas which are more amenable to borrowing (material culture, fauna, flora) have so far been detected. However, data from families for which reliable documentation is available and whose phonological correspondences with Jê are better established, namely, Karajá (Davis 1968 and Ribeiro 2004a), Ofayé (Gudschinsky 1971 and Ribeiro 2005), Maxakalí (Davis 1968), and Krenák (Seki 2002), will be used whenever suitable cognates are found.

\footnotetext{
${ }^{29}$ According to the glottochronological method (as described in, e.g., Jeffers and Lehiste 1992), the time depth between Arikapú and Djeoromitxí could be estimated at about 18 centuries, based on the percentage (58\%) of reconstructed shared vocabulary from the Swadesh 100-word list (see Appendix A). We have not adopted this estimate as a fact, however, because the glottochronological method has been proven to be unreliable.

${ }^{30}$ Greg Urban estimates the age of Proto-Jê as "three thousand years or more," suggesting that "[T]he Jê languages are more diversified internally than the ones of the Romance family of IndoEuropean" (Urban 1998:90 [our translation]).
} 


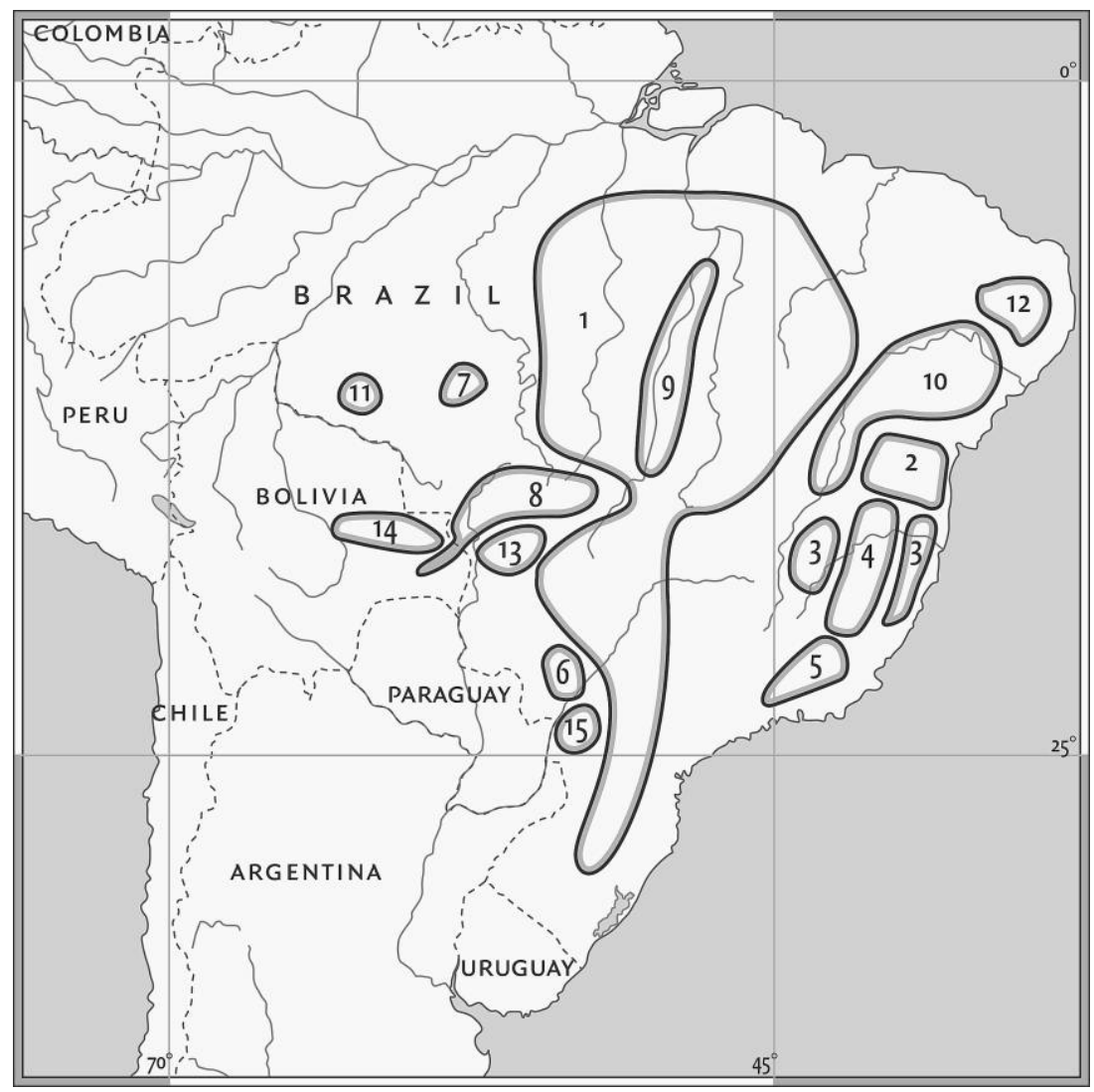

FIG. 1.-Distribution of the Macro-Jê language families.

3.1. The Macro-Jê stock as a genetic grouping: a brief appraisal. The Macro-Jê stock comprises the Jê family and a number of possibly related language families, most of which are located in Brazil. The term "Macro-Jê" was introduced by Mason (1950), replacing earlier labels such as "Tapuya" and "Tapuya-Jê" (for a historical overview of the Macro-Jê stock, see Rodrigues 2002). Although there is agreement on the inclusion of most of the families (table 9), recent classifications (Rodrigues 1986, Greenberg 1987, and Kaufman 1990) differ as to the precise scope of Macro-Jê. Given the lack of comprehensive comparative studies, Macro-Jê remains largely a "working hypothesis" (Rodrigues 1999), the present paper being a good example of its tentative nature. Two other examples will suffice: Guató and Chiquitano. In the case of Guató, whose inclusion is agreed upon by all major classifications, the purported evidence is particularly scanty, and a 
TABLE 9

THE MACRO-JÊ HYPOTHESIS

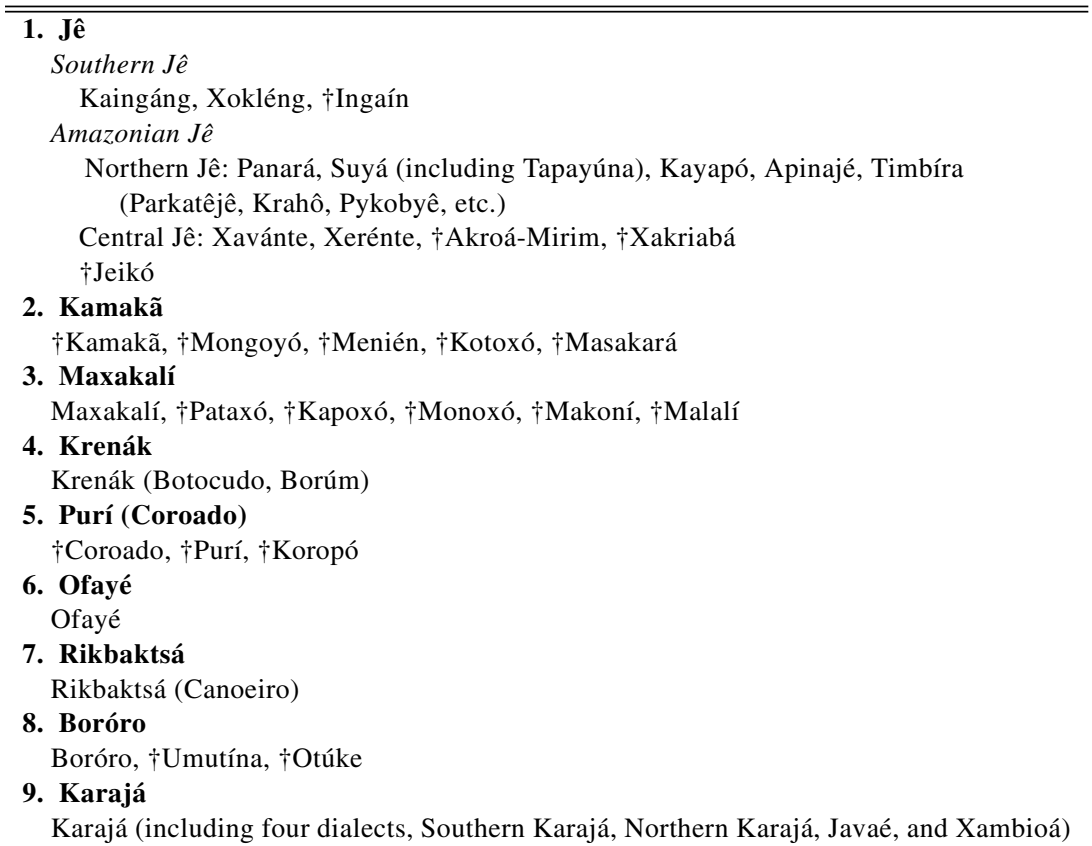

10. Karirí

$\dagger$ Kipeá, $†$ Dzubukuá, $†$ Pedra Branca, $†$ Sabuyá (included by Rodrigues, but not Greenberg and Kaufman)

11. Jabutí

Djeoromitxí (Jabutí), Arikapú (included by Nimuendajú [2000] and Greenberg but not Rodrigues and Kaufman)

12. Yatê

Yatê

13. Guató

Guató

14. Chiquitano

Chiquitano (Besiro) (included by Greenberg and Kaufman but not Rodrigues)

15. Otí

†Otí (Eo-Xavánte) (the inclusion of Otí, proposed only by Greenberg, is not substantiated by the available data)

For more on the Macro-Jê Hypothesis, see Ribeiro (2006).

Extinct languages are indicated by $\dagger$.

thorough search for cognates in the main source on the language (Palácio 1984) reinforces our belief that this language should not be included in the stock. On the other hand, although the inclusion of Chiquitano has been far from a consensus, recent studies (Adelaar 2008 and Santana 2006) have uncovered interesting grammatical, phonological, and lexical similarities, far 
more compelling than those proposed as evidence for the inclusion of Guató (Rodrigues 1986; 1999).

The only family-level reconstructions available are Davis (1966) and Ribeiro (forthcoming), for Proto-Jê. ${ }^{31}$ So far, lexical comparative evidence supporting the inclusion of individual families in the Macro-Jê stock has been presented for Kamakã (Loukotka 1932), Maxakalí (Loukotka 1931; 1939 and Davis 1968), Purí (Loukotka 1937), Boróro (Guérios 1939), Krenák (Loukotka 1955 and Seki 2002), Karajá (Davis 1968), Ofayé (Gudschinsky 1971 and Ribeiro 2005), and Rikbaktsá (Boswood 1973). In addition, some studies have shown very suggestive cases of morphological idiosyncrasies shared by Jê, Boróro, Maxakalí, Karirí, Karajá, and Ofayé (Rodrigues 2001 and Ribeiro 2002a; 2004a; 2007). In sum, evidence for the inclusion of different families in the Macro-Jê stock is rather uneven, ranging from the fairly proven (Maxakalí, Krenák, and other, extinct Eastern Macro-Jê languages, Ofayé, Karajá, etc.) to the virtually untested (Guató and, to a lesser degree, Yatê). Even in those cases for which inclusion in the Macro-Jê stock is beyond question, much more comparative research is needed so that additional cognates can be identified and more accurate correspondences can be established. ${ }^{32}$ The map in figure 1 shows the distribution of all possible members of the Macro-Jê linguistic stock. The numbers correspond to the language families listed in table 9.

3.2. Geographic distribution and internal classification. With the exception of Chiquitano (which is spoken mostly in Bolivia, with a small number of speakers in Mato Grosso, Brazil), all Macro-Jê languages are spoken in Brazilian territory, although in the past Otúke (Boróro) and Ingaín (Southern Jê), both now extinct, were spoken in Bolivia and Argentina, respectively. Although Rikbaktsá and some Jê languages (Kayapó, Suyá, Panará) are spoken on the southern fringes of the Amazon, the overall distribution of Macro-Jê languages is typically non-Amazonian. Yatê, Krenák, and Maxakalí languages are spoken in eastern Brazil, the same having been the case for Purí, Kamakã, and Karirí (all now extinct). Since several pur-

\footnotetext{
${ }^{31}$ For recent attempts at reconstructing Proto-Purí and Proto-Kamakã, see Silva Neto (2007) and Martins (2007), respectively.

${ }^{32}$ Thus, the ongoing study of Ofayé by one of the authors (Ribeiro) makes possible an assessment of the previous work done by Gudschinsky $(1971$; 1974) — until recently, the main source available on this severely endangered Macro-Jê language. As it turns out, Gudschinsky's comparative work presents serious methodological problems, including arbitrary word segmentations and the failure to recognize borrowings (Ribeiro 2005). Also, for Rikbaktsá, Boswood's estimate of $38 \%$ cognacy seems to be too optimistic, since many of her purported correspondences are very poorly attested (Boswood 1973). If that is the situation for families for which comparative studies were conducted, one can assume that the situation is far less satisfactory for the remaining ones.
} 
ported Macro-Jê languages were spoken in eastern Brazil, a number of them became extinct early on, under the impact of European colonization, Yatê being the only surviving indigenous language in the Brazilian northeast (not including Maranhão). Central and Northern Jê tribes (here included under a single branch of the Jê family, Amazonian Jê), as well as the Boróro and the Ofayé, traditionally occupy the savanna areas of Central Brazil. The southernmost Macro-Jê languages are those belonging to the southern branch of the Jê family, spreading from São Paulo to Rio Grande do Sul. Karajá is spoken along the Araguaia River, in Central Brazil. The traditional Guató territory is the Paraguay River, near the Bolivian border.

On geographic grounds, Rodrigues (1999) divides his Macro-Jê families into three groups: Eastern (Purí, Krenák, Maxakalí, Kamakã, Karirí, and Yatê), Central (Karajá and Jê), and Western (Boróro, Guató, Ofayé, and Rikbaktsá). However, he does not attempt to provide internal classifications on genetic grounds. A first attempt at internal genetic classification was recently made by Ribeiro (2007), who suggests that four out of Rodrigues's six eastern families (Maxakalí, Krenák, Kamakã, and Purí) may form a subgroup inside the stock. If that claim is confirmed by further research, this will have important implications for theories about the original homeland of ProtoMacro-Jê, and for claims such as the one made in this paper (see 5).

3.2.1. A note on Proto-Jê. The existence of Jê as a language family has been recognized since early classifications of Brazilian languages (von Martius 1867), although the inclusion of Kaingáng (and closely related Southern Jê languages) was traditionally controversial. For instance, Loukotka (1932) initially included Kaingáng in the Jê family but later on changed his mind (Loukotka 1939). On the other hand, Nimuendajú, in his late years, was convinced that Kaingáng was indeed part of the family (Nimuendajú and Guérios 1948). This issue remained unsettled until Davis demonstrated, on comparative grounds, that Kaingáng should be included in the family, although admitting it to be "a rather divergent member of the family" (Davis 1966:11). As the contentious history of the inclusion of Kaingáng suggests, both Northern and Central Jê languages are much closer to each other than to Southern Jê languages, forming a particular branch (here termed "Amazonian Jê") inside the family. This has obvious implications for Macro-Jê studies, since a form attested only for a branch of the family may very well be an innovation. Davis did not take into account this potential problem; about one-third of his reconstructions were attested only for Amazonian Jê. Furthermore, Davis's comparative work presents a number of additional problems, including false cognates, lack of morphological information, and incorrect reconstructions.

A case in point is the absence, in Davis's reconstruction, of word-initial *w. Although Northern Jê languages are conservative in several aspects (for 
TABLE 10

Reconstruction of Proto-JÊ * $w$ in Word-Initial Position

\begin{tabular}{lccccccc}
\hline \hline & Davis & APINAJÉ & SUYÁ & KAYAPÓ & XERÉnte & KAINGÁNG & Ribeiro \\
\hline 'wood, firewood' & $* p \tilde{\imath}$ & $p \tilde{\imath}$ & $h^{w} \tilde{\imath}$ & $p \tilde{\imath}$ & $m m \tilde{\imath}$ & $p \tilde{\imath}$ & ${ }^{*} p \tilde{\imath}$ \\
'to kill' & $* p \tilde{\imath}$ & $p \tilde{\imath}$ & $p \tilde{\imath}$ & $b \tilde{\imath}$ & $w \tilde{\imath}$ & & $\begin{array}{c}* w \tilde{\imath} \\
\text { (PAJê only) }\end{array}$ \\
\hline
\end{tabular}

See Davis (1966) and Ribeiro (forthcoming).

instance, the preservation of essentially the entire vowel inventory of ProtoJê), the fact that many of Davis's Proto-Jê forms are identical with Apinajé words may mean that Davis relied too much on data from this language (at that time one of the best-described Jê languages). This had a number of undesirable consequences for his reconstruction, since Apinajé presents significant innovations in the consonantal system. For instance, Davis reconstructs the roots meaning 'to kill' and 'wood' as homophonous. However, as the examples in table 10 show, they are only homophonous in Apinajé, since Apinajé merged PJê $* w$ and $* p$.

Given these and other shortcomings of Davis's reconstruction, the ProtoJê (and Proto-Amazonian Jê) forms adopted in this paper are exclusively those reconstructed by Ribeiro (forthcoming); additional comparative remarks on Proto-Jê and its relationship to other families are from the same source.

3.3. Main characteristics of Macro-Jê. Macro-Jê languages are typologically very similar, a fact which, in and of itself, cannot be taken as a sign of genetic relationship. The majority of Macro-Jê languages are verb-final, with postpositions instead of prepositions and possessor-possessed order in genitive constructions - exceptions being Guató (which, as suggested above, should probably be excluded from the stock), Chiquitano, and Karirí. For the latter two, however, internal evidence seems to point to an older SOV pattern, revealed by the behavior of adpositions and compounds (Rodrigues 1999 and Ribeiro 2007, for Kariri; Adelaar 2008, for Chiquitano).

Most Macro-Jê languages have a relatively simple morphology. In most languages, including those of the Karirí, Krenák, Jê, Ofayé, and Maxakalí families, productive inflectional morphology is limited to person marking, the same paradigms being generally shared by nouns, verbs, and adpositions alike. Table 11 illustrates the series of singular personal prefixes in Jê languages, all of which can be reconstructed for Proto-Jê, many with likely cognates in other Macro-Jê families, such as Maxakalí and Karajá.

The personal prefix series includes a linking morpheme (traditionally called "relational prefix" [Rodrigues 2001]), which occurs with most vowel-initial stems whenever they are immediately preceded by an absolutive argument 
TABLE 11

Personal Prefixes IN Jê

\begin{tabular}{|c|c|c|c|c|c|c|}
\hline & \multirow[b]{2}{*}{ PROTO-JÊ } & \multicolumn{2}{|c|}{ NORTHERN JÊ } & \multicolumn{2}{|c|}{ Central Jê } & \multirow{2}{*}{$\begin{array}{c}\text { SOUTHERN JÊ } \\
\text { KAINGÁNG }\end{array}$} \\
\hline & & APINAJÉ & PARKATÊJÊ & Xavante & Xerente & \\
\hline 1 & $* \tilde{i} j-$ & in- & $i-$ & $\tilde{l}^{\prime}-$ & $\tilde{\imath}^{-}$ & in- \\
\hline 2 & $* a-$ & $a-$ & $a-$ & $a-$ & $a-$ & $a-$ \\
\hline 3 & $* \tilde{l}_{-}$ & $i-$ & $\emptyset-$ & $\tilde{\imath}-$ & $\tilde{\imath}-$ & \\
\hline 3 & $*_{s-}$ & $\emptyset-$ & $h$ - & $s-$ & $s-$ & $* \emptyset-$ \\
\hline REL & $* j-$ & $j-, t f, n$ & $j-, t \int_{-}$ & $z^{-}, n^{-}$ & $z_{--}^{-}, n^{-}$ & $* j-$ \\
\hline
\end{tabular}

(possessors, with nouns; objects, with transitive verbs and postpositions; and, in some languages, subjects, with intransitive verbs). As the Suyá (44) and Karajá (45) examples below illustrate, most vowel-initial roots present at least two stem-forms, one with the linking prefix (cognate with Proto-Jê $* j$-) and the other with a third-person marker (cognate with Proto-Jê *s-):

(44a) kntircye y-aykwa

boy LP-mouth

'the boy's mouth'

(44b) s-aykwa

3-mouth

'his mouth'

(45a) dore d-e

parrot LP-wing

'the parrot's wing'

(45b) $d-e$

3-wing

'its wing'

Notice that two third-person markers are reconstructed for Proto-Jê: $*_{\tilde{\imath} \text { - }}$ occurs with consonant-initial stems, whereas $*_{s \text { - occurs with vowel-initial }}$ stems (in complementary distribution with the linking prefix $* j$-). For the sake of clarity, $j$ - stems (that is, stems which present $*_{s-} / *_{j}$ - alternating forms) are given here preceded by the linking prefix. Considering that the equivalents of $*_{j}$ - in other families (as well as in Kaingáng, a Southern Jê language) may be reanalized as a part of the stem, ${ }^{33}$ it seems appropriate to

\footnotetext{
${ }^{33}$ In a few cases, it is the third-person marker * $s$ - which becomes fossilized as part of the root.
} 
use STEMS (linking prefix + root), rather than bare ROOTS, as the basis for the comparison.

In addition to personal prefixes (including linking morphemes), Jê languages also present a number of semi-fossilized prefixed elements (which, as the personal prefixes, occur with both noun and verb stems), whose semantic and grammatical properties tend to be rather vague. As Oliveira describes them, for Apinajé, such elements are "fossilized morphological debris that simply subcategorize words into morphological or semantic classes at the synchronic level" and "tend to be semantically empty or of elusive meaning" (2005:82). Most of these morphemes (a sample of which includes Apinajé $\check{c}-u-, j-a-, k u-$, and $k a-$ ) can be reconstructed for Proto-Jê. The examples in (46), from Apinajé, illustrate the classificatory value of some of these morphemes:

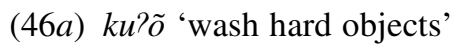

(46b) ka? õ 'wash soft objects'

Although they tend to be relatively fossilized, they were probably still productive in the proto-language, since cognate stems may take different prefixes in different languages (or may not take any prefix at all). Compare the following examples from Apinajé (Northern Jê) and Kaingáng (Southern Jê):

(47a) PJê * $m \dot{t}$ 'tail' > Apinajé $j$-ami vs. Kaingáng $m \dot{t}$

(47b) PJê * prí 'path' > Apinajé pri vs. Kaingáng jãpri

(48a) PJê *wẽ 'to speak' > Apinajé kapẽe, Kaingáng wĩ

(48b) PJê *tẽm 'to come' > Apinajé tẽm, Kaingáng kãtĩy

Tense and aspect distinctions are generally conveyed by particles and auxiliaries, rather than inflectionally. Noun incorporation is rare, having been reported for Karajá and a few Northern Jê languages such as Panará and Parkatêjê. There are, however, a few fossilized noun-verb compounds, which may have resulted diachronically from noun incorporation (e.g., Apinajé j-arkje 'to yawn' < PJê *j-ar- 'mouth' + *kje 'open'; Kaingáng nĩpe

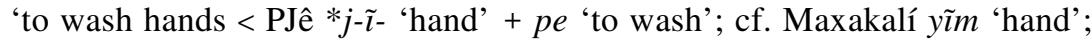
Ofayé $j$ - $\tilde{\imath}$ 'hand'; Karajá $d-\varepsilon$ - 'arm').

A few languages present more complex morphologies, but in those cases for which comparative evidence is available, morphological complexity can be shown to be an innovation. Panará is a case in point, providing an interesting example of "polysynthesis in the making" (when compared to closely related Northern Jê languages), with productive noun incorporation, applicatives (originated from incorporated postpositions), and classifiers (Dourado 2001; 2002). Karajá also presents a fairly complex verb morphology, but, once again, the "core" morphology, comprising derivational suffixes and pronominal prefixes immediately attached to the stem, is what has clear cog- 
TABLE 12

PRoto-JÊ VOWEL INVENTORY

\begin{tabular}{|c|c|c|c|c|c|}
\hline \multicolumn{3}{|c|}{$\overline{\text { Oral }}$} & \multicolumn{3}{|c|}{ Nasal } \\
\hline$i$ & $\dot{i}$ & $u$ & $\tilde{l}$ & $(\tilde{t})$ & $(\tilde{u})$ \\
\hline$e$ & $\partial$ & $o$ & $\tilde{e}$ & & $\tilde{o}$ \\
\hline \multirow[t]{2}{*}{$\varepsilon$} & 3 & o & & & \\
\hline & $a$ & & & $\tilde{a}$ & \\
\hline
\end{tabular}

nates in Macro-Jê (as would be expected; the closer to the stem, the more likely it is for an affix to be older [see Givon 2000]). ${ }^{34}$

While inflectional morphology is predominantly prefixing, derivational morphology is generally suffixing. As with inflectional prefixes (table 11), most derivational suffixes in Jê are retentions from Proto-Jê (or, at least, from Proto-Amazonian Jê). These include a causativizer (PJê *-n), diminutive (PAJê $*_{-} r \varepsilon$ ), augmentative (PAJê *-ti), an agent-noun suffix (PAJê

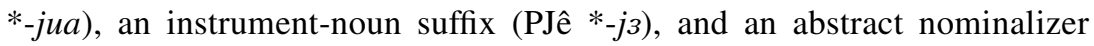
(PAJê $*_{-} r$ ). The latter three have likely cognates in at least another MacroJê language, Karajá (- $d v$ 'subject-noun suffix', $-d a$ 'instrument-noun suffix', -r- 'nominalizer' [see Ribeiro 2008]).

When compared to languages of other lowland South American families (such as Carib and Tupí), Jê languages typically present larger vowel inventories. As table 12 illustrates, Proto-Jê had a system of ten oral vowels and at least four nasal ones. Karajá has an even larger vowel inventory (with twelve oral vowels and three nasal ones), but most Macro-Jê languages display smaller inventories; Maxakalí, for instance, has only five oral vowels, all with nasal equivalents (Popovich and Popovich 2005). As comparative

\footnotetext{
(i) $k a-r-I-d-\partial d I=k r e$

1-CTRG-TRANS-3-lay=FUT

'I will lay it down'.

(ii) $\emptyset-r-I-w a-l$-ədI $=k r e$

1-CTRG-TRANS-1-REL-lay=FUT

'She will lay me down'.

(iii) $k a-r-\emptyset-a-r I=k r e$

1-CTFG-TRANS-2-leave=FUT

'I will leave you'.
}

${ }^{34}$ The examples below illustrate the categories for which the Karajá verb inflects: person, direction, voice, and object (tense is expressed by a clitic). Notice that the prefix $d$ - 'third person' (i) is a cognate of Proto-Jê $*_{s-}$ and, as in Jê, occurs with noun stems as well. The verb stem, $l$ $\partial d I$, is cognate with Proto-Jê $*_{j-i}$ 'to lay' and presents in both families an alternation involving the relational prefix: Karajá $l$-adI (ii) vs. $d$-adI (i); PJê $* j-i$ vs. ${ }^{*} s-i$. Example (iii) illustrates another Karajá verb stem with a Jê cognate ( $r I$ 'to leave behind', PJê * $r \varepsilon$ ), taking the second-person object prefix $a$ - (again, a cognate with Proto-Jê $* a$-). 
TABLE 13

Vowel Raising In Central Jê: Front Vowels

\begin{tabular}{lllll}
\hline \hline & PROTO-JÊ & NORTHERN JÊ & CENTRAL JÊ & SOUTHERN JÊ \\
\hline 'to plant' & $* k r \varepsilon$ & KRA $k r \varepsilon$ & XER $k r e$ & KAI $k r \varepsilon$ \\
'nest' & $* j-a s e$ & API $j-a e$ & XER $z$ - $a s i$ & KAI $j a \eta \phi e$ \\
'to lay' & $* j-i \sim s-i$ & API $t \int-i$ & XER $h i$ & KAI $\phi i$ \\
'instrumental' & $*_{-j} j$ & API $-t f_{3}$ & XER $-z \varepsilon$ & KAI $-j a$ \\
\hline
\end{tabular}

evidence becomes available, it seems clear that Jê is indeed more conservative, whereas languages such as Maxakalí underwent considerable merging, leading to smaller vowel inventories.

Northern Jê languages inherited the Proto-Jê vocalic system practically unchanged (as illustrated by Suyá [Santos 1997]), whereas Central and Southern Jê languages underwent pervasive processes of vowel shift—although the end results, in terms of inventory, are vocalic systems which are only minor deviations from Proto-Jê (major phonological contrasts, such as the distinction between open and close-mid vowels, having been preserved). Table 13 illustrates the process of vowel shift involving front vowels in Central Jê, with systematic raising of $*_{\varepsilon}$ to /e/ and of $*_{e}$ to /i/; the gap that would have resulted from the raising of $*_{\varepsilon}$ is filled by the fronting of $*_{3}$.

Another common phenomenon in Jê languages (as well as in Ofayé) is the insertion of "echo vowels" at the end of words ending in a consonant (most commonly, approximants): OFY $\phi a r$ 'foot' [' $\Phi^{\mathrm{w}}$ ara?], etc. Such extraprosodic vowels are generally unstressed, but in (Proto-)Central Jê they seem to have been reanalyzed as part of the stem. In Xerente, where there is a strong tendency toward vowel deletion (both diachronically and synchronically), the original vowel (probably, after losing stress) is deleted: *['para] 'foot' > *[pa'ra] > [pra]. Comparatively, this process is important because it provides an explanation for apparent (and illusory) cases of metathesis: PJê *par > XER pra. The fact that such correspondences are found inside the Jê family makes a comparison such as PJê * par :: PJab * praj more plausible. A similar process was probably at play in Karajá, which would explain why a correspondence involving a (C)CVC word in Proto-Jê has the vowel showing up in a different syllable in Karajá:

$\begin{array}{ll}\text { (49a) PJê *j-am, KRJ } l \text {-əba } & \text { 'to stand' } \\ \text { (49b) PJê *prãm, KRJ raba } & \text { 'hunger' } \\ \text { (49c) API } m \varepsilon n, \text { KRJ } b a d I & \text { 'honey' } \\ \text { (49d) API } m u r, \text { KRJ } b r v & \text { 'to cry' }\end{array}$

Syllabic patterns are rather simple, obstruent clusters being limited to $\mathrm{C}_{1} \mathrm{C}_{2} \mathrm{~V}$ (where $\mathrm{C}_{1}$ is a plosive and $\mathrm{C}_{2}$ is *r): PJê *pri 'path', *kra 'offspring', *prãm 'hunger', etc. Proto-Jê, as well as the present Jê languages, allows 
TABLE 14

Proto-JÊ CONSONANT InVENTORY

\begin{tabular}{lllll}
\hline \hline$p$ & $t$ & & $k$ & $(?)$ \\
$m$ & $n$ & & $\eta$ & \\
& $s$ & & & \\
$w$ & $r$ & $j$ & & \\
\hline
\end{tabular}

syllables to end in a consonant, including stops. In Kaingáng, Proto-Jê final stops underwent systematic lenition (PJê *pek 'fart' > KAI pej; PJê *tot 'hard' > KAI tar, etc.). Stress is generally predictable, falling on the last syllable, with the apparent exception of Rikbaktsá (Silva 2005). Phonologically contrastive tone oppositions occur in Yatê and Guató (Palácio 1984). Processes such as nasal spreading and vowel harmony are generally absent. An exception is Karajá, which presents [ATR] ("advanced tongue root") vowel harmony, a rare phenomenon among South American languages (Ribeiro 2002b).

As table 14 shows, there was no contrast between voiced oral and nasal plosives in Proto-Jê (a situation that is preserved in most Jê languages). This also occurs in several other Macro-Jê families, including Karajá, Maxakalí, Krenák, and Ofayé. When one considers the reflexes in all the branches of the family (as well as correspondences with other families), it is likely that the nasal consonants were pronounced as fully nasal around nasal vowels and as semi-nasalized voiced stops elsewhere. ${ }^{35}$

Although a few aspects of the Proto-Jê phonological inventory remain to be worked out, ${ }^{36}$ phonological correspondences between the different members of the family are mostly well established. That is obviously important for comparative purposes, since it enables us to detect likely cognates even

\footnotetext{
${ }^{35}$ The symbol $* s$ in table 14 is used to represent a phoneme whose regular reflexes are $/ \mathrm{s} /$ in Panará, /s/ in Suyá, /h/ in Timbira, /s/ in Central Jê (/h/, before PJê *i; /z/ before PJê *ỉ), zero (or a glottal stop) in Apinajé and Kayapó, / $\$$ / in Kaingáng, and /ð/ in Xokléng. Davis (1966) reconstructs it as $*_{z}$, but when one considers the reflexes listed above, ${ }^{*} s$ seems to be a better approximation to its likely pronunciation.

${ }^{36}$ These are indicated by the parentheses in the inventory tables. Most Jê languages present glottal consonants (a stop, a fricative, or both), but comparative evidence for their reconstruction is still inconclusive (except for Timbira / $\mathrm{h} /$ and Apinajé $/ ? /$, which tend to be regular reflexes of Proto-Jê * $s$, and instances of Central-Jê /h/, which trace back to *k, before Proto-Jê high vowels). Possible cognates found so far are still questionable. For instance, the existence of Kaingáng $h$ ə 'body' and Central Jê $h$ ə 'body' would in principle allow the reconstruction of a form with a glottal fricative in Proto-Jê (*hə 'body'), but the vowel correspondence would be irregular (Kaingáng $/$ / / corresponds regularly to Central Jê $/ \varepsilon /$ ); in addition, the Central Jê form could be related to $h ə$ 'skin' (< PAJê * $k \dot{t}$ 'skin'). Therefore, the similarity between Kaingáng and Central Jê in this case could be accidental. The reconstruction of a glottal stop seems at first to be corroborated by the existence of Kaingáng $p \tilde{a} 7 i$ 'chief' (Xokléng pa?i) and Apinajé pa?i 'chief' (cognates of
} 
in cases for which a word cannot (so far) be reconstructed for one (or both) of the proto-languages (see 4.1). ${ }^{37}$

\section{The evidence for the Jabutí-Macro-Jê hypothesis. As mentioned} in the introductory sections, the Jabutí languages used to be regarded by some as being related to the Jê languages. Nimuendajú includes them in the Jê linguistic family on his ethno-historical map (IBGE 1981 [1944]) on the basis of lexical data provided by Snethlage, and Greenberg (1987) classifies them as belonging to the Macro-Jê stock. This classification is usually accepted by typological linguists, but not by the majority of Americanists. In most other authoritative works on South American languages, such as Rodrigues (1986), Campbell (1997), Dixon and Aikhenvald (1999), Loukotka (1968), and Kaufman (1990), the Jabutí languages are assumed to constitute an isolated family. Now that abundant data of high quality have finally been obtained, it is time to revise the classification of Jabutí languages and to evaluate the possible consequences this may have for current ideas about the prehistoric expanse of the speakers of Macro-Jê languages..$^{38}$ In the follow-

which occur in other Northern Jê languages as well), leading to the reconstruction of *pa?i for Proto-Jê. There is a possibility, however, that this may be a loanword from Tupí-Guarani languages, possibly introduced independently in Southern Jê and Northern Jê (cf. Guarani pa?i 'priest; head of an extended family', etc.). As for the vowels, the existence of the nasals * $\tilde{u}$ and $*_{\tilde{t}}$, reconstructed by Davis (1966), is also questionable (perhaps even synchronically, in the Northern Jê languages for which they are described as being phonemic). The only item that Davis reconstructs as containing the vowel * $\tilde{t}$ is 'to sit', reconstructed by Davis as * $n \tilde{t}$. However, in both Central and Southern Jê, the vowel in this stem is the same as obvious reflexes of

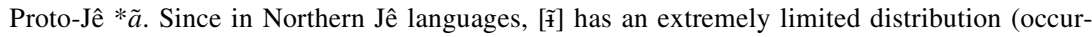
ring generally around glides), it is likely that this pronunciation emerged as the result of height assimilation. Whether this analysis is synchronically valid as well is a subject for further research. Similar arguments can be used against the reconstruction of $* \tilde{u}$.

${ }^{37}$ This is a methodological point that needs to be stressed, especially inside the field of MacroJê comparative studies, where claims of genetic relationship are often based on superficial similarities. A case in point is Rodrigues's purported evidence for a genetic relationship between (Macro-)Jê and Tupí, a major part of which involves an apparent correspondence between ProtoTupí-Guarani * $p$ and Kaingáng / $\Phi /$ (e.g., Proto-Tupí * $p e^{n}$ 'to weave', KAI $\phi \varepsilon n$ 'to spin', etc. [Rodrigues 1985:395-96; 2000:102]). However, a comparative look at other (Macro-)Jê languages shows that Kaingáng / $\Phi /$ traces back to Proto-Jê * $s$ : PJê * se 'thread' > Panará se, Parkatêjê he, Xokléng $\partial e$, etc. Kaingáng $\phi \varepsilon n$ is actually a derived form, including the noun root $\phi e$ 'thread' and the causativizing suffix $-n$ ( $<$ PJê ${ }^{*}-n$; vowel lowering is regularly triggered by the suffixation of $-n$ ). Cases such as these make one suspect that many of the purported Kaingáng/Tupí cognates proposed by Rodrigues are accidental, superficial similarities (for further details, see Ribeiro [forthcoming]).

${ }^{38}$ The reconstructed Proto-Jê items in this article are from Ribeiro (forthcoming). Maxakalí data are from Pereira (1992) and from Popovich and Popovich (2005). Additional sources are Seki (2002), for Krenák; Tremaine (2007), for Rikbaktsá; Oliveira (2005), for Apinajé; Ferreira (2003), for Parkatêjê; Dourado (2001), for Panará; McLeod and Mitchell (1977), for Xavánte; Krieger and Krieger (1994), for Xerénte; Reis Silva (2001), for Kayapó; and Wiesemann (1978; 2002), for Xokléng and Kaingáng. Original transcriptions of the data are maintained. 
ing sections, we present lexical and grammatical evidence for the genetic relationship between the Jê and Jabutí families (corroborated, whenever possible, by data from other Macro-Jê families).

4.1. Lexical evidence. In this section, we present lexical comparative evidence for the genetic relationship between the Jabutí and Jê families, based on recent reconstructions of both Proto-Jabutí, by van der Voort (2007), and Proto-Jê, by Ribeiro (forthcoming). Note that both reconstructions took place independently from one another: van der Voort reconstructed Proto-Jabutí without any prior knowledge of (Macro-)Jê linguistics, while Ribeiro had over the years produced comparative studies of Macro-Jê languages without ever having looked at Jabutí. Only after the basic facts of both proto-languages were established were the results compared.

The likely cognates are distributed into three different tables, according to their degree of attestation. Table 15 includes only elements which can be reconstructed for both proto-languages. Table 16 includes items that can be reconstructed for only one of the proto-languages, as they are attested only in individual languages in the other family. Finally, table 17 includes items that were attested only in individual members of both families. As much as possible, likely cognates which would require arbitrary "morphological" segmentations were avoided. ${ }^{39}$ In all three tables, the first column includes information on whether an item is part of Swadesh's 100-word list; the numbers refer to the original numbers in Swadesh's list (see Appendix A).

Most correspondences are rather straightforward. As the descriptive summaries given above show, Jabutí and Jê (as Macro-Jê languages in general) are isolating, presenting very little productive morphology. The comparative study suggests that this is an inherited feature of these languages and not a result of independent phonological or morphological erosion. Most reconstructed stems, in both proto-languages, are monosyllabic or (though rarely) disyllabic; the few exceptions are old compounds (e.g., PJê *j-akua 'mouth', ${ }^{40} \mathrm{PJab} * t f a k o$ ) or possible loans. ${ }^{41}$

\footnotetext{
${ }^{39}$ The few exceptions-three, to be exact-are cognates 18, 35, and 46. For the possible existence of a morphological entity $* t \int u$ - in Jabutí (cf. cognate 35 ), see DJE runã vs. ARI nõ 'to sit'. Further research on the Jabutí languages may help corroborate this hypothesis.

${ }^{40}$ For Proto-Jê, Ribeiro (forthcoming) reconstructs two items with the meaning 'mouth': *j-ar-, an element that occurs in compounds (cf. PRK $j$-ar-ko 'saliva' $<* j$-ar $+* \eta o$ 'water'), and a freestanding word $* j$-arkua (probably an original compound including $* j$-ar-and a so far unidentified morpheme). Two similar forms may also be reconstructed for Proto-Jabutí: a freestanding word, *tfako (which probably includes the morpheme * $k o$ 'hole') and a compound element *tfa (cf. ARI tfati 'labret; lit., mouth-ornament' vs. tfapati 'upper-arm bracelet; lit., arm-ornament').

${ }^{41}$ An example is the word for 'anteater', reconstructed for Proto-Jabutí as *patfuri, a form that is strikingly similar to Karaja wariri 'anteater' (also a possible cognate is the Amazonian Jê form, e.g., Apinajé pət). Although the phonological correspondences seem to be regular, similar forms occur in Karib and Tupí languages as well. Therefore, even though this may
} 
TABLE 15

Jê/Jabutí Cognates I: In Both Proto-Languages

\begin{tabular}{|c|c|c|c|c|}
\hline (Swadesh) & PROTO-JÊ & & PROTO-JABUtí & $\begin{array}{c}\text { Other } \\
\text { Families }\end{array}$ \\
\hline $1(1)$ & $* \tilde{i} j-$ & '1st person' & $*_{i-}$ & MXK $\tilde{t} k-$, etc. \\
\hline $2(2)$ & $* a-$ & '2nd person' & $* a-$ & $\begin{array}{l}\text { MXK } \tilde{a}-, \text { OFY } \varepsilon-, \\
\text { KRJ } a-, \text { etc. }\end{array}$ \\
\hline 3 & $* \tilde{\imath}_{-}^{-}$ & '3rd person' & $* i-$ & MXK $\tilde{t}-$, KRJ $i-$, etc. \\
\hline 4 & $* k r a$ & 'offspring' & $* k r a(j)$ & KRJ $r a$ 'nephew' \\
\hline $5(46)$ & *par & 'foot' & $* \operatorname{pra}(j)$ & $\begin{array}{r}\text { MXK pata, OFY } \\
\phi a r, \text { KRJ } w a\end{array}$ \\
\hline $6(42)$ & $\begin{array}{l}* \text {-arkua } \\
* j \text {-ar- }\end{array}$ & 'mouth' & $\begin{array}{l}* t \int a k o \\
* t \int a-\end{array}$ & OFY $\int-\varepsilon r$ \\
\hline $7(60)$ & $* j-\tilde{o} t$ & 'to sleep' & $*_{n u \tilde{t} \tilde{o}}$ & MXK $y \tilde{o} n$, OFY $j-\tilde{o} r$ \\
\hline $8(29)$ & $* j-\tilde{l}$ & 'meat, flesh' & $* n \tilde{\imath}$ & $\begin{array}{l}\text { MXK yin, KNK } n i k, \\
\quad \text { KRJ } d \varepsilon\end{array}$ \\
\hline $9(17 a)$ & $* j-u m$ & 'father' & $* t \int u$ & OFY $\int \partial w$, KRJ $d \partial b \dot{t}$ \\
\hline $10(43)$ & $* j-u a$ & 'tooth' & $*$ tfo & $\begin{array}{l}\text { MXK } x o x, \mathrm{KNK} \\
\quad 3 u n, \mathrm{OFY} \varepsilon \varepsilon, \mathrm{KRJ} \\
\quad d z-u\end{array}$ \\
\hline 11 & $* j-u(r)$ & 'pus' & $* t f u$ & \\
\hline $12(58,59)$ & *ma & 'to hear; know' & *ma & МХK $p a k$, OFY $\phi a j$ \\
\hline $13(53)$ & *ma & 'liver' & *ma & OFY $\phi a$, KRJ $b a$ \\
\hline $14(23,34)$ & $* k o$ & 'tree, wood; horn' & $* k u$ & MXK kip, KRJ $k o$ \\
\hline $15(27,28)$ & $* k \dot{t}$ & 'skin, bark' & $* k a$ & MXK $x a x$, КNK kat \\
\hline $16(55 \mathrm{a}, 56)$ & $* k u$ & 'to eat, to bite' & $* k u$ & \\
\hline $17(8 \mathrm{a})$ & $* t \tilde{o}$ & 'NGTVZR' & $* t \tilde{o}$ & KNK $n \tilde{u} \eta$ \\
\hline 18 & $* p a$ & ''arm' & *tfapa & OFY $\phi \varepsilon$, RIK - $p a$ \\
\hline 19 & *so & 'to suck' & $* u$ & $\begin{array}{l}\text { MXK KNK } 3 \supset p, \text { KRJ } \\
\quad d J\end{array}$ \\
\hline $20(31)$ & $*_{s i}$ & 'bone' & $*_{i}$ & $\begin{array}{l}\text { KNK } 3 \varepsilon k, \text { OFY } h i, \\
\quad \text { KRJ } d I\end{array}$ \\
\hline $21(68)$ & $* j-\tilde{a}$ & 'to sit' & $\left(*^{*} n \tilde{a}\right)$ & MXK $y \tilde{t} m$, KRJ $d \tilde{z}$ \\
\hline $22(24)$ & $*_{s \dot{t}}$ & 'seed' & *hã & $\begin{array}{l}\text { MXK } x a p, \text { KNK } \\
3 a m, \text { OFY } \int a, \\
\text { KRJ } d \dot{t}, \text { RIK } z i k \\
\text { 'pit' }\end{array}$ \\
\hline 23 & $*_{j-i}$ & $\begin{array}{l}\text { 'to lay, to put in } \\
\text { lying position' }\end{array}$ & $\begin{array}{c}* d 3 i \text { 'to keep } \\
\text { have, put } \\
\text { place, hide' }\end{array}$ & KRJ $l$-ədII 'to lay' \\
\hline
\end{tabular}

Despite its cursory nature, the sample of likely cognates provided in tables 15-17 shows many regular correspondences:

$$
\begin{aligned}
& \text { PJê * } p:: \text { PJab * } p(5,18) \\
& \text { PJê *t }:: \text { PJab * } t(7,17)
\end{aligned}
$$

eventually turn out to be a legitimate cognate, it cannot, at this stage of the research, be used as a piece of evidence for genetic relationship. 
TABLE 16

Jê/Jabutí Cognates II: In ACtual Languages and Proto-LanguageS

\begin{tabular}{|c|c|c|c|c|}
\hline (Swadesh) & $\overline{J E \hat{E}}$ & JABUTí & & Other Families \\
\hline $24(26)$ & $* j$-are & DJE rari & 'root' & MXK -xatit, KRJ $* l-a d 3 i$ \\
\hline $25(8)$ & API $m \tilde{a}$ & *mãj & 'no' & \\
\hline & $\mathrm{XAV} m \tilde{a}$ & & & \\
\hline 26 & $* m \tilde{a}$ & DJE $m \tilde{a}$ & 'dative' & KRJ $b \tilde{z}$ \\
\hline $27(36)$ & $* j$-ar & DJE rari & 'wing' & RIK sara \\
\hline 28 & API $m o p$ & $* m u$ & 'yam' & \\
\hline 29 & API $m \varepsilon n$ & DJE $m \varepsilon$ & 'honey' & KRJ $b \partial d I$ \\
\hline 30 & API $n-\tilde{o}$ & $* n \tilde{u}$ & 'food' & $\mathrm{KRJ} d \partial$ \\
\hline 31 & KAI - $p e$ & $* p i$ & 'wash, to' & MXK pix, RIK pik \\
\hline $32(33)$ & $* \eta r \varepsilon$ & ARI $r \tilde{\varepsilon}$ & 'egg' & KRJ $\theta I$ \\
\hline 33 & $* \eta r \varepsilon$ & ARI $r \tilde{\varepsilon}$ 'to dance' & 'to sing; to dance' & $\begin{array}{l}\text { MXK kitex 'to sing', } \\
\text { KNK } y r i \text { 'to sing', } \\
\text { OFY gri 'to sing', } \\
\text { KRJ } \theta I \text { 'to dance' }\end{array}$ \\
\hline 34 & API $t \int-w a$ & $* t$ to & 'to bathe' & \\
\hline 35 & SUY $p i$ & $* t \int u w i$ & 'go up' & \\
\hline $36(44)$ & $* j-\tilde{o t \jmath}$ & DJE $n \tilde{t} t \varepsilon$ & 'tongue' & $\begin{array}{l}\text { OFY j-orra, KRJ } d \text { - } \\
\quad \operatorname{sr\partial }(d \supset)\end{array}$ \\
\hline 37 (16a) & PRK tfe & $* d_{3} i$ & 'mother' & RIK je \\
\hline $38(83)$ & *mro & ARI $m r \partial$ & 'ashes, dust' & $\begin{array}{l}\text { MXK putok 'ashes', } \\
\text { KNK proy 'ashes' }\end{array}$ \\
\hline 39 & $* w i$ & DJE $w a$ & 'to catch' & $\begin{array}{l}\text { MXK } p a \text { 'to catch', KRJ } \\
\quad w i \text { 'to carry' }\end{array}$ \\
\hline 40 & API $n$ - $\tilde{o}$ & $* \tilde{u}$ & 'to give' & $\begin{array}{l}\text { MXK hõm, KNK } \tilde{u} m \sim \\
\quad 2 \tilde{u} m, \text { KRJ } \tilde{o}\end{array}$ \\
\hline 41 & API $m \partial r \sim m u r$ & *mo & 'to cry' & $\mathrm{KRJ} b U \sim b r v$ \\
\hline 42 & API ton & $* t \tilde{w} w$ & 'armadillo' & \\
\hline 43 & XAV $n$-õro & *nũrõ & 'cord, rope' & \\
\hline
\end{tabular}

PJê * $k::$ PJab * $k(4,6,14,15,16)$

PJê * $m::$ PJab * $m(12,13)$

PJê ${ }^{*} j$ :: PJab *t (before oral vowels: $6,9,10,11$ )

PJê ${ }^{*} j$ :: PJab * $t$ (before front high oral vowel: 23 )

PJê ${ }^{*} j::$ PJab * $n$ (before nasal vowels: $7,8,21$ )

PJê ${ }^{*} r::$ PJab * $r(4,5,6)$

PJê * $s::$ PJab * $\emptyset$ (before PJab high vowels: 19, 20)

PJê * $s::$ PJab * $h$ (elsewhere)

Having worked out the major correspondences between Proto-Jê and Proto-Jabutí, we can now take into account the cognates in tables $16^{42}$ and

${ }^{42}$ The Karajá form in item 24 occurs in a likely compound, l-adzikura 'cassava' (cf. kura 'white'). 
TABLE 17

JÊ/Jabutí Cognates III: In ACtual LANGUAGES ONLY

\begin{tabular}{|c|c|c|c|c|}
\hline (Swadesh) & $\mathrm{J} \hat{\mathrm{E}}$ & JABUTí & & Other Families \\
\hline 44 & API $m \varepsilon n$ & DJE $m \varepsilon$ & 'honey' & KRJ $b a d I$ \\
\hline $45(77)$ & $* k \varepsilon n$ & $* k r a$ & 'stone' & KNK $k r a k$ \\
\hline 46 & API krat & ARI $n \tilde{k} k r a$ & 'hips' & \\
\hline 47 & KAI jãra & ARI $t$ farij & 'saliva' & \\
\hline $48(39)$ & API yar3 & $* n \tilde{l} p \dot{t}$ & 'ear' & $\begin{array}{l}\text { MXK yĩpkox (cf. kox } \\
\text { 'whole'), RIK spi }\end{array}$ \\
\hline 49 & & $* k o$ & 'hole' & MXK kox \\
\hline 50 & & ARI $m o$ & 'arrow' & MXK pox \\
\hline 51 & $\mathrm{XAV} s \tilde{o}$ 'to wash' & DJE $h \tilde{o}$ 'to wet' & $\begin{array}{l}\text { 'to bathe, to wash, } \\
\text { to wet' }\end{array}$ & KNK hũm 'to bathe' \\
\hline 52 & PRK $t a$ & ARI $t a-$ & '3rd person' & BOR $t \dot{t}$, RIK $t a$ \\
\hline 53 & & ARI tfaro & 'leaf' & RIK saro \\
\hline 54 & & DJE $u$ & 'tail' & KRJ $d v$ '(a bird's) tail' \\
\hline
\end{tabular}

$17,{ }^{43}$ those for which reconstruction was not possible for one or both protolanguages. ${ }^{44}$

Besides corroborating and refining the correspondences detected in table 15, the additional data reveal new correspondences (for instance, PJê ${ }^{*} w$ :: PJab *w). Tables 18 and 19 summarize such correspondences.

As described in the introductory sections, Jê languages present consonant-final syllables, whereas Jabutí languages do not (except for the glide $* j)$. As the comparative data above demonstrate, coda consonants seem to have been lost in Jabutí, with very few exceptions (cognates 7 and 27). Some correspondences are either poorly attested or remain unaccounted for. For instance, examples showing the Proto-Jabutí equivalent of Proto-Jê $* n$ are conspicuously absent in the compared corpora. Correspondences involving Proto-Jê $* s$ are also poorly attested; however, if it turns out that the wordinitial consonant alternations found in Djeoromitxí are historically related to similar processes in Jê and other families, then the initial consonant in the morphologically free forms (DJE hapa 'arm', hakt 'mouth', etc.) would be an

\footnotetext{
${ }^{43}$ The Djeoromitxí form in item 51 was documented by Pires (1992) and does not occur in van der Voort's database.

${ }^{44}$ Northern Jê languages are very closely related and lexically conservative. Therefore, all the examples from Apinajé, Parkatêjê, and Suyá provided here are common to the entire Northern Jê branch. Apinajé generally represents well the languages of the branch, but not always. In the case of cognate 35, for instance, Apinajé has a form identical to Suyá: pi. However, when one considers that Apinajé $/ \mathrm{p} /$ traces back to both PJê $* p$ and $* w$, comparing PJab *tfuwi to the Apinajé form would be less reliable. Suyá $/ \mathrm{p} /$, however, clearly traces back to PJê $* w$; thus, the Suyá form corroborates the identification of a correspondence between PJê $* w$ and $\mathrm{PJab} * w$.
} 
TABLE 18

Phonological CoRrespondences BetweEn JÊ AND Jabutí: Consonants

\begin{tabular}{lll}
\hline \hline JÊ & \multicolumn{1}{c}{ JABUTí } \\
\hline$* p$ & $* p$ & \multicolumn{1}{c}{ Cognates } \\
$* t$ & $* t$ & $7,18,31$ \\
$* k$ & $* k$ & $4,6,14,15,16,46$ \\
$* m$ & $* m$ & $12,13,25,26,28,29,38,44$ \\
$* n$ & $* n$ & \\
$* \eta$ & $* \emptyset$ & 32,22 \\
$* r$ & $* r$ & $4,5,6,24,27,32,33,36,38,46,47$ \\
$* s$ & $* \emptyset$ (before PJab high vowels) & 19,20 \\
$* s$ & $* h$ (elsewhere) & 22,51 \\
$* j$ & $* t f$ (before oral vowels) & $6,9,10,11,24,27,47$ \\
$* j$ & $* n$ (before nasal vowels) & $7,8,21,30,36,43$ \\
$* w$ & $* w$ & 35,39 \\
\hline
\end{tabular}

TABLE 19

Phonological CoRRESPondenCES BetweEn Jê AND Jabutí: Vowels

\begin{tabular}{|c|c|c|}
\hline$\overline{\mathrm{JE}}$ & JABUTí & Cognates \\
\hline$*_{i}$ & $*_{i}$ & $20,23,35$ \\
\hline$*_{i}$ & $* a$ & $22(?), 39$ \\
\hline$* u$ & $* u$ & $9,11,16$ \\
\hline$*_{e}$ & $*_{i}$ & $24,31,37$ \\
\hline \multicolumn{3}{|l|}{$* \partial$} \\
\hline$* o$ & $* u$ & $14,19,28$ \\
\hline$*_{\varepsilon}$ & $*_{\varepsilon}$ & $32,33,34$ \\
\hline$*_{3}$ & $\mathrm{ARI} / \mathrm{i} /$ & 47 \\
\hline$* 2$ & DJE / / / & 36 \\
\hline$* a$ & $* a$ & $2,4,5,6,18,24,27,47,52$ \\
\hline \multicolumn{3}{|l|}{$* \tilde{e}$} \\
\hline$* \tilde{o}$ & $* \tilde{u}$ & $7,30,36,40,43,51$ \\
\hline$* \tilde{\imath}$ & $* \tilde{\imath}$ & 8 \\
\hline$* \tilde{a}$ & $* \tilde{a}$ & $21,25,28$ \\
\hline *ua & $* o$ & $6,10,34$ \\
\hline
\end{tabular}

obvious cognate of the Proto-Jê third-person prefix * $s$ - (cf. Suyá $s$-ajkwa 'his mouth', $s$-wa 'his tooth', etc.).

Both Proto-Jê and Proto-Jabutí have remarkably similar consonantal inventories. The lack of contrast between voiced stops and their nasal counterparts (common in many-if not most-Macro-Jê languages, such as those of the Jê, Maxakalí, and Karajá families) is also preserved in Jabutí. One of the few differences is the absence, in Proto-Jabutí, of a nasal velar * $\eta$, a phoneme that tends to be fairly less stable cross-linguistically. 
Vowel correspondences are less obvious-but, nonetheless, mostly regular. If one assumes (as it seems) that Jê is more conservative, a general process of vowel raising, involving mid vowels as a natural class, seems to have taken place in Pre-Proto-Jabutí, close-mid vowels in Proto-Jê corresponding systematically to high vowels in Jabutí (cf. 24, 31, 37, 14, 19, 28); the data suggest that, as in Central-Jê, close-mid vowels would have merged with the original high vowels in Jabutí. The Proto-Jê sequence *ua is regularly reflected in Proto-Jabutí as a single vowel, ${ }^{*} o$, possibly as the result of monophthongization (cognates 6, 10,34). Some gaps in the comparative tables are probably a consequence of the rarity of certain phonemes; ProtoJê * ${ }^{*}$, for instance, is particularly rare in the comparative corpus. Additional research will, we hope, help to fill such gaps.

4.1.1. Homophonous pairs. If, as the comparative method assumes, sound changes tend to be regular, and two different words happen to sound the same in a given proto-language, one expects that these words will still be homophonous in the daughter languages, unless lexical replacement or some irregular factor is at play. Consequently, corroborating the regularity of the phonological correspondences postulated above is the fact that cases of homophony in one language tend to correspond to homophonous pairs in the other. Thus, the words for 'to hear' (50a) and 'liver' (50b) are homophonous in both Proto-Jê (*ma) and Proto-Jabutí (*mə); the words for 'tooth' $(50 c)$ and 'to bathe' $(50 d)$, homophonous in Proto-Jabutí (*tfo), are also homophonous in Northern Jê (e.g., Apinajé $t$-wa 'tooth', $t$-wa 'bathe'; Northern Jê $t$, in such cases, traces back to Proto-Jê $* j)$. The words for 'egg' $(50 e)$ and 'dance' $(50 f)$, homophonous in Proto-Jê (* $\eta r \varepsilon)$, are also homophonous in Arikapú ( $r \tilde{\varepsilon}$ 'egg', $r \tilde{\varepsilon}$ 'to dance'). Finally, both 'meat, flesh' and 'thorn' are homophonous in Proto-Jabutí (*nĩ), Northern Jê (Apinajé $n i$ ), and Rikbaktsá (-ni). ${ }^{45}$

$\begin{array}{lll}\text { JÊ FAMILY } & \text { JABUtí FAMILY } & \text { MeANING } \\ (50 a) * m a & * m ə & \text { 'hear, know' } \\ (50 b) * m a & * m ə & \text { 'liver' } \\ (50 c) \text { API } t f-w a & * t f o & \text { 'tooth' } \\ (50 d) \text { API } t f-w a & * t f o & \text { 'to bathe' } \\ (50 e) * \eta r \varepsilon & \text { ARI } r \tilde{\varepsilon} & \text { 'egg' } \\ (50 f) * \eta r \varepsilon & \text { ARI } r \tilde{\varepsilon} & \text { 'to dance' } \\ (50 g) \text { API } n i & * n \tilde{\imath} & \text { 'flesh' } \\ (50 h) * j-\tilde{l} & * n \tilde{\imath} & \text { 'thorn' }\end{array}$

\footnotetext{
${ }^{45}$ Another example is a "minimal pair" for the contrast between * $t$ and $* r$ (in Proto-Jabutí and, maybe, Proto-Jê). In both Proto-Jabutí and Xavante (Central Jê), the words for 'rope' and 'to sleep' are nearly homophonous, except for the consonant in the second syllable (cf. Xavante

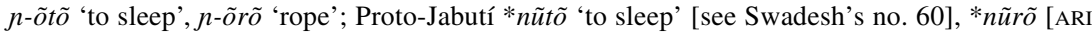
nũrã, DJE nõñ̃] 'rope made of tucuma').
} 
TABLE 20

Personal Prefixes in Jabutí

\begin{tabular}{cccc}
\hline \hline & PRoto-Jabutí & ARIKAPÚ & DJeOROMitXí \\
\hline 1 & $* i-$ & $i-$ & $\emptyset-$ \\
2 & $* a-$ & $a-$ & $a-$ \\
3 & $* i-$ & $i-, \emptyset-$ & $i-$ \\
\hline
\end{tabular}

TABLE 21

Personal Prefixes in Jê AND MaXaKalí

\begin{tabular}{|c|c|c|c|c|c|}
\hline & \multicolumn{4}{|c|}{$\mathrm{JE} \hat{\mathrm{E}}$} & \multirow[b]{3}{*}{ MAXAKALÍ } \\
\hline & \multicolumn{2}{|c|}{ NORTHERN Jê } & \multicolumn{2}{|c|}{ Central Jê } & \\
\hline & APINAJÉ & PARKATÊJÊ & XaVAnte & Xerente & \\
\hline 1 & in- & $i-$ & $\tilde{\imath}:-$ & $\tilde{\tau^{-}}$ & $\tilde{t} k-$ \\
\hline 2 & $a-$ & $a-$ & $a-$ & $a-$ & $\tilde{a}-$ \\
\hline 3 & $i-$ & $\emptyset-$ & $\tilde{l}^{-}$ & $\tilde{l}^{-}$ & $\tilde{t}-$ \\
\hline
\end{tabular}

(50e) and (50f) have additional explanatory value. As mentioned in the Arikapú descriptive section above, the nasal vowel / $/ \tilde{\varepsilon} /$ is very rare, and most of its occurrences can be explained as a consequence of nasal spreading from a following syllable, resulting in the nasalization of $/ \varepsilon /$. The only minimal pair available involves the homophonous stems $r \tilde{\varepsilon}$ 'egg'/'to dance' and the classifying stem $r \varepsilon$ 'worm'. But, thanks to comparative evidence, the (apparently exceptional) nasality in this case can be explained as a leftover from a formerly existing $* \eta$.

4.2. Grammatical evidence. The series of singular personal prefixes that has been reconstructed for Proto-Jabutí (table 20) is strikingly similar to the prefix series found in Jê and other well-established Macro-Jê languages, such as Maxakalí (table 21). The comparative corpora include a few examples of inflected words presenting both prefix and root cognates between both families (51); note that, in (51), the roots can be reconstructed for at least one of the proto-languages:

$\begin{array}{lll}\text { PARKATÊJÊ } & \text { ARIKAPÚ } & \text { MEANING } \\ \text { (51a) } \text { intfum } & \text { itfu } & \text { 'my father' } \\ \text { (51b) intfe } & \text { itfi } & \text { 'my mother' } \\ (51 c) \text { ikra } & \text { ikraj } & \text { 'my child' }\end{array}$

Notice that in Arikapú there is homophony between the first- and thirdperson prefixes; not surprisingly, such a homophony leads to ambiguity 
between a first-person and a third-person "generic" reading (e.g., i-t fawa 'my flower' '(its) flower'; $i$-t fapa 'my arm' '(its) branch'). Such ambiguity does not occur in Djeoromitxí, where a zero-form emerged representing the first person.

Remarkably, a similar state of affairs can also be found in Jê languages. In Proto-Jê (as in Maxakalí), the first- and third-person prefixes differ phonologically only by the occurrence, with the former, of a final consonant (as illustrated by languages such as Apinajé). In languages such as Xerente (Central Jê) and Parkatêjê (Northern Jê), phonological processes leading to homophony between the first- and third-person prefixes tend to cause ambiguity and, consequently, innovations in the prefix system. Thus, in Parkatêjê, the first-person prefix is $i$-, which would be homophonous with the inherited third-person marker (table 21); the adoption of a zero-prefix for the third person prevents ambiguities. The fact that Arikapú is more conservative than Djeoromitxí, preserving both prefixes despite their homophony, makes such similarities between both families rather evident.

An additional example of likely grammatical affinity between both families (the existence of "linking prefixes") is discussed below (4.3).

\subsection{Arikapú and Djeoromitxí in a comparative perspective: an}

evaluation. Despite the fact that Jabutí is a very small family and that both of its members are still rather similar, it is important to emphasize that Djeoromitxí and Arikapú each contribute essential bits of information to the reconstruction of Proto-Jabutí-and, consequently, to the detection of evidence of wider genetic relationships. For instance, Arikapú is phonologically more conservative, preserving, among other things: $(a)$ vowel distinctions which were apparently lost in Djeoromitxí (* $i$ vs. $\left.{ }^{*} I\right) ;(b)$ consonant clusters $\left(* m r,{ }^{*} p r,{ }^{*} k r\right)$, simplified in Djeoromitxí; and $(c)$ an independent reflex of Proto-Jabutí $* t \int$ (which, in Djeoromitxí, merged with reflexes of Proto-Jabutí *r).

The importance, for comparative studies, of such conservativeness of Arikapú, a previously undescribed language with only two speakers, cannot be stressed enough (see Moore [forthcoming]). Considering the isolating, monosyllabic nature of Jabutí-and Macro-Jê_-words, one can see that any processes that lead to further loss of phonological material pose additional challenges for the comparative linguist. The fact that Arikapú preserves consonantal clusters allows the identification of correspondences which would otherwise be harder to detect (note Arikapú kraj 'offspring' :: ProtoJê *kra, etc.).

In one aspect, Arikapú is also morphologically more conservative, preserving the complete series of singular personal prefixes, $i$ - 'first person', $a$ - 'second person', and $i$ - 'third person', in spite of the ambiguity resulting from the homophony between the first- and third-person markers. This makes 
it more evident that the COMPLETE SERIES of singular personal prefixes in Proto-Jabutí and Proto-Jê were cognates, which provides a stronger piece of evidence than the existence of individual personal prefixes alone. The fact that in both Arikapú and several Jê languages the first- and third-person prefixes became homophonous only adds to the strength of the proof.

There is at least one aspect in which Djeoromitxí seems to be morphologically more conservative than Arikapú. As we have seen, a number of noun and verb stems in Djeoromitxí present a word-initial morphophonemic alternation between $r-\sim n$ - when there is a morphologically contiguous determiner, and $h$ - elsewhere. This is a fully productive process in Djeoromitxí but not in Arikapú. However, the existence of a few, apparently frozen, relic alternations in Arikapú (e.g., haroko tfaroko 'to speak') seems to suggest that such a process can be reconstructed for Proto-Jabutí.

For those acquainted with (Macro-)Jê languages, the alternations found in Djeoromitxí are strikingly similar to the ones involving the so-called relational prefixes, a morphological peculiarity described for Jê and other Macro-Jê families (Rodrigues 2001 and Ribeiro 2004a). As the phonological correspondences show, the consonants involved in the alternations found in Djeoromitxí, which trace back to Proto-Jabutí $* n$ - and $* t f-(53)$, correspond regularly to Proto-Jê $*_{j}(52)$, which happens to be the consonant of the "relational prefix" in the languages of this family. ${ }^{46}$

(52a) PJê *j-ĩ 'meat' > Kaingáng nĩ , Apinajé $n-\tilde{\imath}$, etc.

(52b) PJê *j-ua 'tooth' > Kaingáng ja, Apinajé tf-wa, etc.

(52c) PJê *j-um 'father' > Kaingáng joy, Parkatêjê $t f-u m$, etc.

(52d) PJê *j-arkua 'mouth' > Kaingáng jãnkã 'door', Apinajé j-akwa, etc.

(53a) PJab *ñ 'meat' > Djeoromitxí nĩ , Arikapú $n \tilde{\imath}$

(53b) PJab *tfo 'tooth' > Djeoromitxí $r t$ htt, Arikapú tfukrihã

(53c) PJab *tfu 'father' > Djeoromitxí $r u \sim h u$, Arikapú $t f u$

(53d) PJab *tfako 'mouth' > Djeoromitxí rakt hakt, Arikapú tfako

It is likely that, in Proto-Jê, $* j$ already had two allophones, pronounced as *[n] before nasal vowels and *[j] elsewhere. In Kaingáng, *[n] became /n/, thus merging with reflexes of Proto-Jê $* n$, whereas $* j$ remains as $/ \mathrm{j} /$. Similar splits are found throughout the family, as well as in other languages of the

$46 * j$ also corresponds regularly to the consonant of the relational prefix in Karajá (Ribeiro $2004 a$ ) and other families. Notice that, unlike its cognates in Northern Jê languages (for instance, Parkatêjê $n-\tilde{\imath}$ 'meat', $h-\tilde{\imath}$ 'its meat'), the word for 'meat', $n \tilde{\imath}$, does not display consonant alternation in Djeoromitxí, although such alternations are found with other stems in the same phonological environment (cf. hihõnõnõda -nihõnõnõda 'to work', in Pires 1992:106;124). However, the initial consonant is also invariable in Central Jê (Xavante $j \tilde{l}$ ) and Karajá $(d \varepsilon)$. It is therefore possible that Northern Jê innovated, reanalyzing the initial consonant as a prefix. 
stock, such as Ofayé (cf. $\int-\varepsilon r$ 'mouth', j-õra [nõ'ra] 'tongue'; cf. respectively Proto-Jê $* j$-ar- and $* j$-otto) ${ }^{47}$ As we have seen, Proto-Jabutí $* n$ and $* t \int$ (in those examples involving alternation) correspond regularly to Proto-Jê $* j$. It is interesting to point out that Arikapú / $\mathrm{t} \int /$ rarely occurs before nasal vowels. This suggests that, at a certain stage of Pre-Proto-Jabutí, $* t f$ and $* n$ were in complementary distribution, a situation reminiscent of the scenario reconstructed for Proto-Jê *j. Again, it is the interplay between data from Arikapú and Djeoromitxí which contributes to provide a clearer picture of ProtoJabutí (and beyond) and of the correspondences between Jabutí and the other Macro-Jê families.

4.4. Jabutí as Macro-Jê: an appraisal. As with any claim of remote relationship, one has to be careful in order to avoid the possibility of chance similarities being misinterpreted as proof of genetic connection. In MacroJê, one of the most controversial language groupings in South America, this possibility is particularly hard to avoid, on account of the isolating (and mostly monosyllabic) nature of the morphemes (Rodrigues 1999; 2001, Campbell 1988:600, and Meillet 1967:55). In addition, some of the grammatical morphemes generally pointed out as evidence of genetic relationship in Macro-Jê are also found elsewhere (the so-called pan-americanisms [Campbell and Kaufman 1983:366]). Taken as a whole, however, the evidence presented here seems to strongly point to a genetic relationship. A number of regular phonological correspondences were detected, in a part of the lexicon that is generally considered as being diachronically stable and less prone to borrowing (many of the compared forms are found in Swadesh's basic list). One major advantage in relation to other works proposing the membership of individual families in the Macro-Jê stock (Davis 1968, Boswood 1973, and Gudschinsky 1971) is that, in the present case, two proto-languages can be compared, thus reducing the possibility of including in the comparison chance similarities and loans, besides increasing the temporal depth by at least two millennia. In proposing the inclusion of Karajá and Maxakalí, Davis (1968) relies on the diagnostic value of the Swadesh list: "Maxakalí and Karajá are included in the same stock with the Jê languages on the basis of the fact that regular sound correspondences are detectable in a relatively small corpus of data and on the basis of lexical similarity. Lexicostatistical comparisons based on the Swadesh 100-word list show about 25\% shared cognates between Maxakalí or Karajá and individual Jê languages."

In the present case, even if we adopt a more conservative approach, computing only the first two categories of cognates (those which can be re-

\footnotetext{
${ }^{47}$ Notice that Ribeiro (forthcoming) reconstructs two forms with the meaning 'mouth': *j-arand $*_{j}$-arkua. Ofayé $f-\varepsilon r$ is a cognate of the former.
} 
constructed for at least one of the proto-languages), we would have a rate of approximately $25 \%$ cognation (23 out of 97 , considering that pairs such as 'hear/know', 'skin/bark', 'wood/horn', which have different entries in Swadesh's list, are one and the same word both in Jabutí and Jê)..$^{48}$ Therefore, based on the same kind of similarities pointed out by Davis in advocating the inclusion of Maxakalí and Karajá in the Macro-Jê stock (improved, in our case, by the careful reconstruction of the proto-languages and by the identification of grammatical similarities), it seems quite reasonable to propose the inclusion of Jabutí in the stock as well.

5. Implications for prehistory. The thesis presented in this article, if confirmed by further scrutiny, would have far-reaching consequences for theories on the prehistoric dispersion of the Macro-Jê-speaking tribes. Current scholarship on Macro-Jê rests on the assumption of a supposedly higher diversity in eastern Brazil, where the majority of the members of the stock would be located. As Urban (1998:91) points out, if families such as Kamakã, Purí, Krenák, and Maxakalí "are only remotely related, this would be an area of great linguistic diversity . . , and, thus, a possible place for the dispersion that took place 5 or 6 thousand years ago." If, however, the aforementioned eastern families are closely related (as proposed by Ribeiro 2007) and additional members of the stock are proven to exist in the far west, current theories will have to be reconsidered. Central Brazil would then be a stronger candidate as the original homeland of Macro-Jê.

6. Conclusion. Although the correspondences shown above may require further refinement, they make a fairly strong case for considering the inclusion of Jabutí in the Macro-Jê stock. As the discussion in $\mathbf{4}$ suggests, there is a considerable degree of regular, recurrent correspondences, including a number of grammatical elements and a possible case of shared aberrancy. Additional research, including an investigation of the apparent cases of shared idiosyncrasies in the personal pronominal prefix systems, may reveal further regularities. Thus, the Jabutí/Macro-Jê hypothesis, first raised by Curt Nimuendajú, is confirmed by our initial findings. Further investigation of the Jabutí languages will no doubt come to enrich the field of Macro-Jê studies in the future.

\footnotetext{
48 The fact that one and the same word combines the meanings 'to hear' and 'to know' may be interesting in itself. Although the convergence between the two meanings can occur independently in unrelated languages, we should note that the use of 'hearing' as a metaphorical locus for 'understanding, awareness, knowledge' is a rather common characteristic in Macro-Jê. In Karajá, for example, 'to be stupid' is 'to not have ears'; 'to hear' (constructed with the noun stem for 'ear') equals 'to understand'; 'to faint' is 'to have (one's) ears clogged'.
} 


\section{APPENDIX A \\ Swadesh Basic Vocabulary fOR the Jabutí LANGUAGES With Proto-Jabutí AND Proto-JÊ Reconstructions}

Below is Swadesh's basic list of 100 words, as represented in Bynon (1983:268). It contains Arikapú and Djeoromitxí forms, as well as reconstructed Proto-Jabutí and Proto-Jê forms wherever available.

\begin{tabular}{|c|c|c|c|c|c|}
\hline 1. & $\begin{array}{l}\text { ENGLISH } \\
\text { I }\end{array}$ & $\begin{array}{l}\text { ARIKAPÚ } \\
i h \varepsilon, i-\end{array}$ & $\begin{array}{l}\text { DJEOROMITXÍ } \\
h t, \emptyset\end{array}$ & PRoto-JAButí & $\begin{array}{l}\text { РRоTо-JÊ } \\
* \tilde{i} j-\end{array}$ \\
\hline 2. & you (SG/PL) & $a h \varepsilon, a-$ & $a d z \varepsilon, a-$ & $* a$ & $* a-$ \\
\hline 3. & we & $t \int i h \varepsilon, t \int i-$ & hirt, hi- & $* h i$ & \\
\hline 4. & this & $\tilde{a} j h \tilde{a}$ & $w \varepsilon$ & & \\
\hline 5. & that & $m w \varepsilon h \tilde{a}, n i h \tilde{a}$ & тире, тє, пидзи & & \\
\hline 6. & who & & & & \\
\hline 7. & what & hẽwha & hatfime & & \\
\hline 8. & not & $m \tilde{a} j$ & $m \tilde{a}$ & *mãj & \\
\hline $8 a$. & not, no & $t \tilde{a}$ & $t \tilde{o}$ & $* t \tilde{o}$ & $* t \tilde{o}$ \\
\hline 9. & all (finished) & hatã & bzitã & $(* . . t \tilde{a})$ & \\
\hline 10. & many & hekumrã & hõta & & \\
\hline 11. & one & 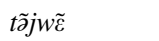 & uitfi & & *pit \\
\hline 12. & two & heri & dзвти & & \\
\hline 13. & big & tfitfi, rukre & tfitfi & $* t f i t f i$ & \\
\hline 14. & long & $r \varepsilon h \tilde{\partial} t f i$ & kuritfi & & \\
\hline 15. & small & $m r a j$ & to & & \\
\hline 16. & woman & pakue & paku & *paku & \\
\hline 16a. & female & $t f i$ & $d 3 i$ & $* d 3 i$ & \\
\hline 17. & $\operatorname{man}$ & onz̃hย & $t f \hat{t}$ & & \\
\hline $\begin{array}{l}17 a . \\
18 .\end{array}$ & $\begin{array}{l}\text { male } \\
\text { person }\end{array}$ & $t \int u, t f u t f i$ & $\begin{array}{l}\text {-ru, hutfi } \\
\text { hikəmнt }\end{array}$ & $* t \int u, t \int u t f i$ & $* j-u m$ \\
\hline 19. & fish & $\operatorname{minu\tilde {u}}$ & $\min \tilde{o}$ & $*_{\min \tilde{u}}$ & \\
\hline 20. & bird & (ammitfi) & mitait $\int u$ & & \\
\hline 21. & $\operatorname{dog}$ & kura & $w a$ & & \\
\hline 22. & louse & tao & $t \tilde{o} d z \varepsilon$ & & \\
\hline 23. & tree, wood & $k u$ & $k u$ & $* k u$ & *ko \\
\hline 24. & seed & $h \tilde{a}$ & $h \tilde{o}$ & $* h \tilde{a}$ & $*_{s i}$ \\
\hline 25. & leaf & -nĩ, tfaro & $n \tilde{\imath}$ & $*_{-n \tilde{\imath}}$ & \\
\hline 26. & root & niri & rari & & $*_{j \text {-are }}$ \\
\hline 27. & bark & $k \partial$ & $k a$ & $* k a$ & $* k \dot{t}$ \\
\hline 28. & skin & $k a$ & ka & $* k a$ & $* k \dot{k}$ \\
\hline 29. & flesh & $n \tilde{\imath}$ & $n \tilde{\imath}$ & $*_{n \tilde{l}}$ & $* j-\tilde{l}$ \\
\hline 30. & blood & tfo & $k \partial i$ & & \\
\hline 31. & bone & $t f i, i$ & $d 3 i$ & $* d 3 i($ or $* i)$ & $*_{s i}$ \\
\hline 32. & grease & tuka & $t \tilde{o}$ & $* \tilde{u}(k a)$ & \\
\hline 33. & egg & $-r \tilde{\varepsilon}$ & $d 3 \varepsilon$ & $*(.) \tilde{\varepsilon}$ & $* \eta r \varepsilon$ \\
\hline 34. & horn & nĩpəkojku & imeku & & $* k o$ \\
\hline 35. & tail & nĩtaj & $u$ & & \\
\hline 36. & feather & to & rari & & $* j$-ar \\
\hline 37. & hair & $k a i$ & kuãhi, hi & & \\
\hline 38. & head & $k a j$ & kuãka & & *krã \\
\hline
\end{tabular}




\begin{tabular}{|c|c|c|c|c|c|}
\hline 39. & ear & nipwaro & nĩpi & $\left(*_{n} \tilde{i p} \dot{i}\right)^{49}$ & \\
\hline 40. & eye & hãkars ${ }^{50}$ & $h \tilde{o} k a$ & *hãka(rc) & \\
\hline 41. & nose & nĩnĩka & $n \tilde{l} k t t \varepsilon$ & & $* j-\tilde{\imath} j a$ \\
\hline 42. & mouth & tfako (nuku) & -rakt/hakt & *tfako & $* j$-arkua \\
\hline 43. & tooth & tfokrihã & $(-) r t$ & $* t \int o$ & $*_{j-u a}$ \\
\hline 44. & tongue & nukutare & $n \tilde{u} t \varepsilon(r \varepsilon)$ & & $*_{j-\tilde{o} t \partial}$ \\
\hline 45. & claw (i.e., nail) & $n \tilde{i} k \partial t a j$ & nikate & *nĩkataj & \\
\hline 46. & foot & praj & pa, panĩkə & *praj & *par \\
\hline 47. & knee & $m \tilde{\varepsilon} p \varepsilon$ & pepe & $*_{m \tilde{\varepsilon}} p \varepsilon^{51}$ & \\
\hline 48. & hand & $n \tilde{k} a j, n \tilde{\imath} k u, n i k u$ & nĩhu, nihu & $*_{n \tilde{\imath} . u^{52}}$ & $*_{n-\tilde{\imath} k r a}$ \\
\hline 49. & belly & prika & pika & *prika & \\
\hline 50. & neck & poko, $(\text { kopo })^{53}$ & $k t p t$ & *poko & \\
\hline $50 \mathrm{a}$. & neck2 & ruwaj & reu & & \\
\hline 51. & breasts & nuni & nowi & *nuni & \\
\hline 52. & heart & məka & mətutuka & $*_{m} \partial(t u t u) k a$ & \\
\hline 53. & liver & mə & mə & *mə & $* m a$ \\
\hline 54. & drink & $o$ & $n \tilde{o}$ & & \\
\hline 55. & eat & $p u$ & pu & $* p u$ & \\
\hline $55 a$. & eat2 & $k u$ & $k u$ & $* k u$ & $* k u$ \\
\hline 56. & bite & $k u$ & $k u$ & $* k u$ & $* k u$ \\
\hline 57. & see & arã & 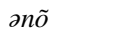 & *arã & \\
\hline 58. & hear & $m \partial$ & mə & *mə & $* m a$ \\
\hline 59. & know & mə & mə & *mə & $* m a$ \\
\hline 60. & sleep & $n \tilde{u} t \tilde{\partial}$ & nõtõ & *nũtõ & $* j-\tilde{o} t$ \\
\hline 61. & die & $p i$ & hahi & & \\
\hline 62. & kill (shoot) & konə & hi, hirokt & & \\
\hline $62 \mathrm{a}$. & kill (club) & $t \tilde{\partial} m r \tilde{\partial}$ & tumi & $* t . m r$. & \\
\hline 63. & swim & (i)pri & $i w a$ & & \\
\hline 64. & fly & tfopo & irariku & & \\
\hline 65. & walk & karaj & dzekire & $(* k \partial r \varepsilon j)^{54}$ & \\
\hline 66. & come (arrive) & praj & $p \varepsilon$ & *praj & \\
\hline 67. & lie & $k \tilde{o r a \tilde{j}}$ & ure & $(* . . r \tilde{a} j)$ & \\
\hline 68. & sit & $n \tilde{a}$ & hunã & & $* j-\tilde{a}$ \\
\hline 69. & stand & $t \int u \varepsilon$ & tumi & & \\
\hline 70. & give & $\tilde{u}$ & $\tilde{o}$ & $* \tilde{u}$ & \\
\hline 71. & say & tfaroko & piru, rumə & & \\
\hline 72. & sun & $\operatorname{tzh} \tilde{a}$ & tõhõ & *tõhã & \\
\hline
\end{tabular}

${ }^{49}$ The Arikapú form is probably a formerly productive combination that included *nĩp 'ear'.

${ }^{50}$ The element $-r \varepsilon$ is possibly a lexicalized suffix with classifying properties.

${ }^{51}$ The words for 'knee' seem partially cognate. We may assume that original word-initial $* m$ merged with $/ \mathrm{p} /$ in Djeoromitxí under denasalization, whereas it was transferred as expected in Arikapú.

${ }^{52}$ Whereas in Djeoromitxí no distinction is made between 'hand' and 'finger', in Arikapú there is one: nĩku 'finger', nĩkaj 'hand', nĩkajku 'all fingers of the hand'. The item 'finger' can be reconstructed in Proto-Jabutí as *nĩku.

${ }^{53}$ This alternative pronunciation is probably due to influence from Djeoromitxí, where metathesis of syllables must have occurred.

${ }^{54}$ The resemblance to the Kwaza (isolate) verb kerai- 'to go, leave, walk' is striking and may be a reason not to reconstruct this item. 


\begin{tabular}{|c|c|c|c|c|c|}
\hline 73. & moon & kupa & kupa & $(* k u p a)$ & \\
\hline 74. & star & wirəwirə & bzircbzire & & \\
\hline $74 a$. & big star & warəwara & kurawãtfi & & \\
\hline 75. & water, liquid & $m i$ & bziru & $*_{m i}(r u)$ & \\
\hline $75 a$. & water, liquid & $\dot{t}$ & $i$ & $\left(*_{i}\right)^{55}$ & \\
\hline 76. & rain & $n \tilde{a j}$ & nipa & & \\
\hline $76 a$. & $\operatorname{rain}(\mathrm{V})$ & roko & $h \tilde{o k t}$ & *rõko & \\
\hline 77. & stone & $k r a$ & $t a$ & $* k r a$ & $* k \varepsilon n$ \\
\hline 78. & sand & kikira & nomart & & \\
\hline 79. & earth & $m \tilde{\imath}(k a)$ & $m \tilde{\imath}(k a)$ & $*_{m \tilde{l}}(k a)$ & *pika \\
\hline 80. & cloud & $m \tilde{\varepsilon}$ & $m \varepsilon(k t t(k t))$ & $*_{m \tilde{\varepsilon}}(k o)$ & \\
\hline 81. & smoke & tfio & 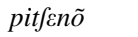 & & \\
\hline 82. & fire & pikə & pitfe & *pitfa & \\
\hline 83. & ash & pikamrə & 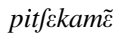 & *pitf $(m r \partial)$ & $*_{m r \nu}$ \\
\hline 84. & burn & kənə & $t \int \varepsilon t u$ & $* t \int \partial(.)$. & \\
\hline 85. & path & $w I$ & wikt & $*_{w I}$ & \\
\hline 86. & mountain & kam̃̃ & tri & & \\
\hline 87. & red & nũrão & nõrt & $*^{*} n \tilde{u} r(\tilde{\partial}) o$ & \\
\hline 88. & green & kapi & kapi & *kapi & \\
\hline 89. & yellow & пити & bzinu & $*_{n и т и j}{ }^{56}$ & \\
\hline 90. & white & $m \tilde{a} \tilde{o}$ & kənũrt & & \\
\hline 91. & black & kario & miru & & \\
\hline 92. & night & patfiu & patfiru & *patfitfu & \\
\hline 93. & hot & $k a$ & $t \int \varepsilon$ & $* t \int \partial$ & \\
\hline 94. & cold & $(k \partial) t f i t f i$ & (dzidzirtu) & & \\
\hline 95. & full & $m ə j$ & $d z \varepsilon(w i)$ & & \\
\hline 96. & new & kamu & kати & *kamu & \\
\hline $96 a$. & new2 & & nute (inan) & & \\
\hline $96 b$. & young girl & nunika & $n \tilde{i} k a$ & *nũntka & \\
\hline 97. & good & $h \tilde{a} w i$ & $m \varepsilon d{ }^{\prime} t$ & & \\
\hline 98. & round & $k a$ & $k a$ & $* k a$ & \\
\hline 99. & dry & karo & kurt & *karo & \\
\hline 100. & name & tatfi & tõh & *tõhi & \\
\hline
\end{tabular}

${ }^{55}$ Note that Tupí languages tend to have a similar form.

${ }^{56}$ A very speculative explanation for the similarities is found in van der Voort $(2007: 159)$. It involves omission of a final glide in both languages, as also observed in *tfamuj, ARI tfamuj, DJE habzi 'cotton' (n. 16), combined with syllable metathesis in Djeoromitxí, as also hypothesized in n. 53 . 


\section{REFERENCES}

AdAm, Lucien. 1893. Matériaux pour servir à l'établissement d'une grammaire comparée des dialectes de la famille caribe. Bibliothèque Linguistique Américaine, vol. 17. Paris: J. Maisonneuve.

Adelaar, Willem F. H. 2008. Relações externas do Macro-Jê: O caso do Chiquitano. Topicalizando Macro-Jê, ed. Stella Telles and Aldir Santos de Paula, pp. 9-28. Recife: NECTAR.

Araújo, Leopoldina M. S. DE. 1989. Aspectos da língua Gavião-Jê. Ph.D. dissertation, Universidade Federal do Rio de Janeiro.

Bacelar, LaÉrcio Nora. 2004. Gramática da língua Kanoê. Ph.D. dissertation, Katholieke Universiteit Nijmegen.

BARROS, ELISSANDRA. 2009. Estruturas fonéticas e fonológicas de consoantes e vogais da língua Kuruaya. M.A. thesis, Universidade Federal do Pará.

Blevins, Juliette. 2004. Evolutionary Phonology: The Emergence of Sound Patterns. Cambridge: Cambridge University Press.

BontKes, Willem. 1968. [Vocabulary of Arikapú]. Ms. (10 pages), Archive, Summer Institute of Linguistics, Porto Velho.

Borges, M. V. 2006. Aspectos fonológicos e morfossintáticos da língua Avá-Canoeiro (Tupi-Guarani). Ph.D. dissertation, Universidade Estadual de Campinas.

BoswOOD, JoAN. 1973. Evidências para a inclusão do Aripaktsá no filo Macro-Jê. Série Lingüística, vol. 1, ed. L. I. Bridgeman, pp. 67-78. Brasília: Summer Institute of Linguistics.

Brijnen, Hélène, ANd Willem F. H. AdelaAR. 2010. Amazonian Languages. Leiden: Universiteitsbibliotheek. 〈https://digihum.leidenuniv.nl/ amazonianlanguages>.

Bynon, Theodora. 1983 [1977]. Historical Linguistics. Cambridge: Cambridge University Press.

Cabral, Ana S. A. C. 1995a. Notas sobre a fonologia segmental do Jo'é. Revista Moara 4:23-46. Belém: Editora da Universidade Federal do Pará. 1995b. Algumas evidências de parentesco genético do Jo'é com as línguas Tupí-Guaraní. Revista Moara 4:47-76. Belém: Editora da Universidade Federal do Pará.

Cabral, Ana S. A. C., And Lucivaldo S. Da Costa. 2004. Xikrín e línguas Tupí-Guaraní: Marcas relacionais. Línguas Indígenas da América do Sul (LIAMES) 4:7-19.

[IJAL, vol. 76, no. 4, October 2010, pp. 571-83]

(c) 2011 by The University of Chicago. All rights reserved.

0020-7071/2010/7604-0006\$10.00 
Cabral, Ana S. A. C.; Aryon D. Rodrigues; and Lucivaldo S. da Costa. 2004. Notas sobre ergatividade em Xikrín. Línguas Indígenas da América do Sul (LIAMES) 4:21-28.

$\rightarrow$ CAmpbell, Lyle. 1988. Review of Language in the Americas by Joseph H. Greenberg. Language 64:591-615.

1997. American Indian Languages: The Historical Linguistics of Native America. New York and Oxford: Oxford University Press.

Campbell, Lyle, and Terrence Kaufman. 1983. Mesoamerican historical linguistics and distant genetic relationship: Getting it straight. American Anthropologist, n.s., 85:362-72.

CAmpBell, RoBert. 1968. [Vocabulary of Jabutí]. Ms. (10 pages), Archive, Summer Institute of Linguistics, Porto Velho.

Carlin, Eithne B. 2004. A Grammar of Trio, a Cariban Language of Suriname. Duisburg Papers on Research in Language and Culture, vol. 55. Frankfurt-am-Main: Peter Lang.

CASPar, Franz. 1952. Tuparí: Unter Indios im Urwald Brasiliens. Braunschweig: Friedr. Vieweg \& Sohn.

1953. Ein Kulturareal im Hinterland der Flüsse Guaporé und Machado (Westbrasilien), dargestellt nach unveröffentlichten und anderen wenig bekannten Quellen, mit besonderer Berücksichtigung der Nahrungs- und Genussmittel. Ph.D. dissertation, Universität Hamburg.

1955a. A expedição de P.H. Fawcett à tribo dos Maxubi em 1914. Anais do XXXI Congresso Internacional de Americanistas, pp. 113-20. São Paulo. 1955b. [Vocabulary of Arikapú]. Ms. (51 pages), Zürich.

1975. Die Tuparí: Ein Indianerstamm in Westbrasilien. Monographien zur Völkerkunde herausgegeben vom Hamburgischen Museum für Völkerkunde, vol. 7. Berlin and New York: Walter de Gruyter.

Castro Alves, Flávia De. 2004. O Timbira falado pelos Canela Apãniekrá: Uma contribuição aos estudos da morfossintaxe de uma língua Jê. Ph.D. dissertation, Universidade Estadual de Campinas.

2007a. Propriedades formais dos sujeitos em Canela. Topicalizando Macro-Jê, ed. Stella Telles and Aldir Santos de Paula. Recife: NECTAR. 2007b. O papel das nominalizações na evolução do alinhamento ergativo nas línguas Jê: Dimensões funcionais e estruturais. Paper presented at Conference on Structures of Amazonian Languages, Manaus.

Cohn, ABigail. 1990. Phonetic and Phonological Rules of Nasalization. UCLA Working Papers in Linguistics, no. 76. Los Angeles: Department of Linguistics, University of California.

1993. A survey of the phonology of the feature [ \pm nasal]. Working Papers of the Cornell Phonetics Laboratory 8:141-203.

COMRIE, BERnARD, AND SANDRA THOMPSON. 1985. Lexical nominalization. Language Typology and Syntactic Description, vol. 3, ed. Timothy Shopen, pp. 349-98. Cambridge: Cambridge University Press. 
Costa, Lucivaldo S. 2003. Flexão relacional, marcas pessoais e tipos de predicados em Xikrín: contribuição para os estudos de ergatividade em línguas Jê. M.A. thesis, Universidade Federal do Pará.

Costa, Raimundo N. V. 1998. Fonologia da língua Kuruaya. M.A. thesis, Universidade Federal do Pará.

Crevels, Mily, And Hein van der Voort. 2008. The Guaporé-Mamoré region as a linguistic area. From Linguistic Areas to Areal Linguistics, ed. Pieter Muysken, pp. 151-79. Amsterdam and Philadelphia: John Benjamins.

Crofts, Marjorie. 1985. Aspectos da Língua Mundurukú. Brasília: Summer Institute of Linguistics.

D’Angelis, Wilmar da R.; Carla M. Cunha; And Aryon D. Rodrigues, eds. 2002. Bibliografia das Línguas Macro-Jê. Campinas: Unicamp.

Da Silva, Raynice G. P. 2005. Estudo fonológico da língua Sateré-Mawé. M.A. thesis, Universidade Estadual de Campinas.

DAvis, Irvine. 1966. Comparative Jê phonology. Estudos Lingüísticos: Revista Brasileira de Lingüística Teórica e Aplicada 1, no.2:10-24.

1968. Some Macro-Jê relationships. IJAL 34:42-47.

Derbyshire, Desmond C. 1985. Hixkaryana and Linguistic Typology. Dallas: Summer Institute of Linguistics and University of Texas at Arlington. 1999. Carib. The Amazonian Languages, ed. R. M. W. Dixon and Alexandra Y. Aikhenvald, pp. 22-64. Cambridge: Cambridge University Press.

$\rightarrow$ Dixon, Robert M. W. 1979. Ergativity. Language 55:59-138.

1994. Ergativity. Cambridge: Cambridge University Press.

Dixon, Robert M. W., And Alexandra Y. Aikhenvald, eds. 1999. The Amazonian Languages. Cambridge: Cambridge University Press.

Dourado, Luciana Gonçalves. 2001. Aspectos morfossintáticos da língua Panará (Jê). Ph.D. dissertation, Universidade Estadual de Campinas. 2002. Construções aplicativas em Panará. Documentação de Estudos em Lingüística Teórica e Aplicada (DELTA) 18:203-31.

FABRE, Alain. 2005. Diccionario Etnolingüístico y Guía Bibliográfica de los Pueblos Indígenas Sudamericanos. 〈http://butler.cc.tut.fi/ fabre/BookInternetVersio/Dic $=\mathrm{J} \%$ ea.pdf $>$.

Fargetti, Cristina M. 1992. Análise fonológica da língua Juruna. M.A. thesis, Universidade Estadual de Campinas.

$\rightarrow$ FAwCETt, Percy Harrison. 1915. Bolivian exploration, 1913-1914. Geographical Journal 45:219-28.

1953. Exploration Fawcett. Ed. Brian Fawcett. London: Hutchinson.

Ferreira, Marília de N. DE Oliveira. 2003. Estudo morfossintático da língua Parkatêjê. Ph.D. dissertation, Universidade Estadual de Campinas.

FRANCHETTO, BRUNA. 2000. O conhecimento científico das línguas indígenas da Amazônia no Brasil. As Línguas Amazônicas Hoje, ed. Francisco Queixalós and Odile Renault-Lescure. São Paulo: Instituto Socioambiental. 
Gabas, Nilson, JR. 1998. Estudo fonológico da língua Karo (arara de Rondônia). Studies in Native American Linguistics, no. 31. Munich: Lincom Europa.

Gakran, NAmblá. 2005. Aspectos morfossintáticos da língua Laklanõ (Xokleng) "Jê." M.A. thesis, Universidade Estadual de Campinas.

Galucio, AnA Vilacy. 1995. Fonologia segmental da língua Mekens. Proceedings of the IX Encontro Nacional da Associação Nacional de PósGraduação em Letras e Lingüística (ANPOLL) 2:988-97.

2001. The morphosyntax of Mekens (Tupi). Ph.D. dissertation, University of Chicago.

2002. O prefixo i- em Tupi: Morfema antipassivo vs. marcador pronominal incorporado. Atas do Encontro Internacional de Pesquisadores de Línguas Indígenas, pp. 274-87. Belém: Universidade Federal do Pará.

Galucio, Ana Vilacy, And Pieter Muysken, eds. 2007. Lingüística Histórica na América do Sul. Boletim do Museu Paraense Emílio Goeldi, Ciências Humanas 2, no. 2. Belém.

GiLdEA, SpIKE. 1989. Simple and relative clauses in Panare. M.A. thesis, University of Oregon.

1994. Semantic and pragmatic inverse: "Inverse alignment" and "inverse voice" in Carib of Surinam. Voice and Inversion, ed. Talmy Givón, pp. 187-230. Amsterdam: John Benjamins.

1995. A comparative description of syllable reduction in the Cariban language family. IJAL 61:62-102.

1998. On reconstructing grammar: Comparative Cariban morphosyntax. Oxford Studies in Anthropological Linguistics, vol. 18. Oxford: Oxford University Press.

2000. On the genesis of the verb phrase in Cariban languages: Diversity through reanalysis. Reconstructing Grammar: Comparative Linguistics and Grammaticalization Theory, ed. Spike Gildea, Typological Studies in Language, vol. 43, pp. 65-106. Amsterdam and Philadelphia: John Benjamins.

2002. Reconstructing Pre-Proto-Tupi-Guarani main clause grammar. A tas do Encontro Internacional de Pesquisadores de Línguas Indígenas, pp. 315-26. Belém: Universidade Federal do Pará.

2004. The Venezuelan branch of the Cariban language family. Amérindia 28:7-32.

Forthcoming. Linguistic studies in the Cariban family. Handbook of South America, ed. Lyle Campbell and Verónica Grondona. Berlin: Mouton de Gruyter.

Gildea, Spike, and Flávia de Castro Alves. 2007. On nominativeabsolutive as a alignment type. Ms., University of Oregon and Universidade de Brasília. 
GildeA, Spike, And Doris Payne. 2007. Is Greenberg's Macro-Carib viable? Lingüística Histórica na América do Sul, ed. A. Vilacy Galucio and Pieter Muysken. Boletim do Museu Emilio Goeldi, Ciências Humanas 2, no. 2. Belém.

GildeA, Spike; Berend Hoff; And Sérgio Meira. 2010. The story of *ô in the Cariban family. Fieldwork and Linguistic Analysis in Indigenous Languages of the Americas, ed. Andrea L. Berez, Daisy Rosenblum, and Jean Mulder, Language Documentation Conservation Special Publication no. 2 (May 2010):91-123.

GirARD, Victor. 1971. Proto-Carib phonology. Ph.D. dissertation, University of California, Berkeley.

Givón, TALMY. 2000. Internal reconstruction: As method, as theory. Reconstructing Grammar: Comparative Linguistics and Grammaticalization Theory, ed. Spike Gildea, pp. 107-59. Amsterdam and Philadelphia: John Benjamins.

2001. Syntax: An Introduction. Vols 1 and 2. Amsterdam: John Benjamins.

Goeje, Claudius H. DE. 1946. Études Linguistiques Caraïbes. Verhandelingen van de Koninklijke Akademie van Wetenschappen, afdeeling letterkunde, no. 49, pt. 2. Amsterdam.

Gomes, Dioney M. 2000. Predicados verbais da língua Mundurukú e modelos lexicográficos. M.A thesis, Universidade de Brasília.

Gonçalves, Solange A. 2007. Aspecto no Kaingang. M.A. thesis, Universidade Estadual de Campinas.

GonzÁlez, Hebe A. 2005. A grammar of Tapiete (Tupi-Guarani). Ph.D. dissertation, University of Pittsburg.

GreenberG, Joseph H. 1959. Essays in Linguistics. Chicago: University of Chicago Press.

1987. Language in the Americas. Stanford, Calif.: Stanford University Press.

GudSCHINSKY, SARAH. 1971. Ofaié-Xavánte, a Jê language. Estudos sôbre Línguas e Culturas Indígenas, ed. Sarah Gudschinsky, pp. 1-16. Brasília: Summer Institute of Linguistics.

1974. Fragmentos de Ofaié: A descrição de uma língua extinta. Série Lingüística, vol. 3, pp. 177-249. Brasília: Summer Institute of Linguistics.

Guérios, Rosário FARANi MANSUR. 1939. O nexo lingüístico BororoMerrime-Caiapó. Revista do Círculo de Estudos Bandeirantes 2:61-74. 〈http://biblio.etnolinguistica.org/guerios-1939-nexo〉.

Hall, Katherine. 1988. The morphosyntax of discourse in De'kwana Carib. Ph. D. dissertation, Washington University, St. Louis.

Harris, Alice C., And Lyle Campbell. 1995. Historical Syntax in CrossLinguistic Perspective. Cambridge: Cambridge University Press. 
Hawkins, Robert. 1998. Waiwai. Handbook of Amazonian Languages, ed. Desmond C. Derbyshire and Geoffrey K. Pullum, pp. 3-202. Berlin: Mouton de Gruyter.

Heine, Bernd. 1993. Auxiliaries: Cognitive Forces and Grammaticalization. New York: Oxford University Press.

Hoenigswald, Henry M. 1960. Language Change and Linguistic Reconstruction. Chicago: University of Chicago Press.

Hoff, Berend. 1968. The Carib Language. The Hague: Martinus Nijhoff. 1995. Configurationality and non-configurationality in the Carib language of Surinam. IJAL 61:347-77.

HyMAN, LARRY M. 1977. Phonologization. Linguistic Studies Offered to Joseph Greenberg, ed. A. Juilland, pp. 407-18. Saratoga, Calif.: Anma Libri.

iBGE, Fundação Instituto Brasileiro de Geografia e Estatística. 1981 [1944]. Mapa etno-histórico de Curt Nimuendajú. Rio de Janeiro: IBGE.

JefFers, RoBert J., AND ILSE Lehiste. 1992 [1979]. Principles and Methods for Historical Linguistics. Cambridge, Mass.: The M.I.T Press.

Jensen, Cheryl J. S. 1984. O desenvolvimento histórico da língua Wayampi. M.A. thesis, Universidade Estadual de Campinas.

1998. Comparative Tupí-Guaraní morphosyntax. Handbook of Amazonian Languages, vol. 4, ed. Desmond C. Derbyshire and Geoffrey K. Pullum, pp. 489-618. Berlin and New York: Mouton de Gruyter.

Kaufman, Terrence. 1990. Language history in South America: What we know and how to know more. Amazonian Linguistics: Studies in Lowland South American Languages, ed. Doris Payne, pp. 13-73. Austin: University of Texas Press.

Koenn, Edward, and Sally Sharp Koenn. 1986. Apalai. Handbook of Amazonian Languages, ed. Desmond C. Derbyshire and Geoffrey K. Pullum, pp. 33-127. Berlin: Mouton de Gruyter.

Krieger, Wanda B., and Guenther Carlos Krieger. 1994. Dicionário escolar Xerente-português, português-Xerente. Rio de Janeiro: Junta das Missões Nacionais da Convenção Batista Brasileira.

LoukotKA, Č́stmír. 1931. La familia lingüística Mašakali. Revista del Instituto de Etnología de la Universidad Nacional de Tucumán 2:21-47.

1932. La familia lingüística Kamakan del Brasil. Revista del Instituto de Etnología de la Universidad Nacional de Tucumán 2:493-524.

1937. La familia lingüística Coroado. Journal de la Société des Américanistes de Paris, n.s, 29:157-214.

1939. A língua dos Patachos. Revista do Arquivo Municipal de São Paulo 55:5-15.

1955. Les indiens Botocudo et leur langue. Lingua Posnaniensis 5:112-35. 
1963. Documents et vocabulaires inédites de langues et de dialectes sud-américains, Journal de la Société des Américanistes, n.s., 52:7-60. 1968. Classification of South American Indian Languages. Ed. Johannes Wilbert. Los Angeles: Latin American Center, University of California.

MacDonell, Ronald Beaton. 1994. La phonologie du Makuxi, langue caribe: Une analyse fonctionnelle. M.A. thesis, Université Laval.

MAldi, Denise. 1991. O complexo cultural do Marico: Sociedades indígenas dos Rios Branco, Colorado e Mequens, afluentes do médio Guaporé. Boletim do Museu Paraense Emílio Goeldi, Antropologia 7, no. 2:209-69.

Martins, Andérbio Márcio Silva. 2007. Revisão da família lingüística Kamakã proposta por Chestmir Loukotka. M.A. thesis, Universidade de Brasília.

Martins Filho, Sinval. 2007. Aspectos morfossintáticos da língua AkweXerente (Jê). Ph.D. dissertation, Universidade Federal de Goiânia.

Martius, CARl Friedrich PhilipP von. 1867. Beiträge zur Ethnographie und Sprachenkunde Amerikas zumal Brasiliens. Vols. 1 and 2. Leipzig: Friedrich Fleischer.

Mason, J. Alden. 1950. The languages of South American Indians. Handbook of South American Indians, vol. 6, Smithsonian Institution Bureau of American Ethnology Bulletin no. 143, ed. Julian H. Steward, pp. 157-317. Washington, D.C.: Government Printing Office.

Mcleod, Ruth, And Valerie Mitchell. 1977. Aspectos da Língua Xavánte. Brasília: Summer Institute of Linguistics.

Meillet, Antoine. 1967. The Comparative Method in Historical Linguistics. Trans. Gordon B. Ford, Jr. Paris: Champion.

MeIrA, SÉrgio. 1999. A grammar of Tiriyó. Ph.D. dissertation, Rice University.

2000a. A Reconstruction of Proto-Taranoan: Phonology and Morphology. Munich: Lincom Europa.

2000b. The accidental intransitive split in the Cariban family. Reconstructing Grammar: Comparative Linguistics and Grammaticalization Theory, ed. Spike Gildea, pp. 201-30. Amsterdam and Philadelphia: John Benjamins.

2002. A first comparison of pronominal and demonstrative systems in the Cariban language family. Current Studies in South American languages, ed. Mily Crevels et al., Indigenous Languages of Latin America (ILLA) Series, vol. 3, pp. 255-75. Leiden: Research School of Asian, African, and Amerindian Studies (CNWS).

2005. Cariban languages. Encyclopedia of Language and Linguistics, 2nd ed., ed. Keith Brown, vol. 1, pp. 199-204. Oxford: Elsevier.

Meira, Sérgio, and Sebastian Drude. 2005. A família Mawetí Guaraní no tronco Tupí. Paper presented at the Simpósio Internacional de 
Lingüística Histórica na América do Sul, Universidade Federal do Pará, Belém, August 25, 2005.

Meira, SÉrgio, And Bruna Franchetto. 2005. The southern Cariban languages and the Cariban family. IJAL 71:127-92.

Mello, Augusto A. S. 2000. Estudo histórico da família linguística TupiGuarani. Ph.D. dissertation, Universidade Federal de Santa Catarina.

$\rightarrow$ Mithun, Marianne. 1991. Active/agentive case-marking and its motivations. Language 67:510-46.

Moore, DenNy. 1984. Syntax of the language of the Gavião Indians of Rondônia, Brazil. Ph.D. dissertation, City University of New York. 1988. Glossário Tuparí-Jaboti-Arikapú. Ms., Archives of the Museu Paraense Emílio Goeldi, Belém. 2006. Brazil: Language situation. Encyclopedia of Language and Linguistics, 2nd ed., ed. Keith Brown, vol. 2, pp.117-28. Oxford: Elsevier. 2007. Endangered languages of lowland tropical South America. Language Diversity Endangered, ed. Matthias Brenzinger, pp. 29-58. Berlin: Mouton de Gruyter.

. Forthcoming. Contributions of highly endangered languages to diachronic linguistics: Examples from Brazil. Proceedings of the Third Oxford-Kobe Linguistics Seminar: The Linguistics of Endangered Languages, ed. Peter K. Austin. London: SOAS.

Moore, Denny, ANd Ana Vilacy Galucio. 1994. Reconstruction of ProtoTuparí consonants and vowels. Survey of California and Other Indian Languages, Report no. 8, ed. Margaret Langdon and Leanne Hinton, pp. 119-30. Columbus: Ohio State University.

Moore, Denny, And Hein van Der Voort, eds. Forthcoming. Amazonian Linguistic Stocks and Their Prehistory.

Moore, Denny; Ana Vilacy Galucio; and Nilson Gabas, Jr. 2008. O desafio de documentar e preservar as línguas amazônicas. Scientific American Brasil: Amazônia, 3:36-43.

Mosonyi, Jorge C. 1978. Diccionario basico del idioma Cariña. Thesis for the title of Profesor Agregado, Universidad Central de Venezuela, Caracas.

Nimuendauú, Curt. 2000 [1923-42]. Cartas do Sertão de Curt Nimuendajú para Carlos Estevão de Oliveira. Ed. Thekla Hartmann. Lisboa: Museu Nacional de Etnologia and Assírio \& Alvim.

Nimuendauú, Curt, And Rosário FArani Mansur Guérios. 1948. Cartas etno-lingüísticas. Revista do Museu Paulista, n.s., 2:207-41. 〈http:// biblio.etnolinguistica.org/nimuendaju_guerios_1948>.

NoRDENSKIÖLD, ERLAND. 1915. Forskningar och Äventyr i Sydamerika. Stockholm: Albert Bonniers.

Ohala, John J. 1981. The listener as a source of sound change. Papers from the Parasession on Language and Behavior, ed. Robert A. Hendrick and Mary Frances, pp. 178-203. Chicago: Chicago Linguistic Society. 
1983. The origin of sound patterns in vocal tract constraints. The Production of Speech, ed. P. F. MacNeilage, pp. 189-216. New York: Springer. 1989. Sound change is drawn from a pool of synchronic variation. Language Change: Contributions to the Study of Its Causes, ed. L. E. Breivik and E. H. Jahr, Trends in Linguistics, Studies and Monographs, no. 43, pp. 173-98. Berlin: Mouton de Gruyter.

Oliveira, Christiane Cunha De. 2003. Lexical categories and descriptives in Apinajé. IJAL 69: 243-74.

2005. The language of the Apinajé people of Central Brazil. Ph.D. dissertation, University of Oregon.

Oliveira, Rosana C. 2007. Morfologia e sintaxe da língua Xavante. Ph.D. dissertation, Universidade Federal do Rio de Janeiro.

Palácio, Adair Pimentel. 1984. Guató: A língua dos índios canoeiros do Rio Paraguai. Ph.D. dissertation, Universidade Estadual de Campinas.

Payne, Thomas, And Doris L. Payne. 1999. Panare: A Cariban language of central Venezuela. Ms., La Trobe University.

PereirA, Deuscreide. 1992. Alguns aspectos gramaticais da língua Maxacali. M.A. thesis, Universidade Federal de Minas Gerais.

Peterson, Tyler, and Gessiane Picanço. 2007. Dynamic correspondences: An object-oriented approach to tracking sound reconstructions. Proceedings of the Ninth Meeting of the ACL Special Interest Group in Computational Morphology and Phonology, ed. J. Nerbonne, T. M. Ellison, and G. Kondrak, pp. 126-33. Stroudsburg, Penn.: Association for Computational Linguistics.

PiCAnço, Gessiane. 2005. Mundurukú: Phonetics, phonology, synchrony, diachrony. Ph.D. dissertation, University of British Columbia.

2008. The development of creaky voice in Proto-Mundurukú (Tupi). Contemporary Phonology in Brazil, ed. L. Bisol and C. R. Brescancini, pp. 288-314. Newcastle: Cambridge Scholars Publishing.

$\rightarrow$ Piggott, Glynn. 1992. Variability in feature dependency: The case of nasality. Natural Language and Linguistic Theory 10:33-78.

PIRES, NÁDIA NASCIMENTO. 1992. Estudo da gramática da língua Jeoromitxi (Jabutí): Aspectos sintáticos das cláusulas matrizes. M.A. thesis, Universidade Estadual de Campinas.

1998. Construções passivas, transitivas e intransitivas em Djeoromitxí. Cadernos de Estudos Lingüísticos 34:147-55.

Pires, Nádia Nascimento; José Roberto Jabutí; And VAndete Jabutí. 1994. Livro de Alfabetização em Djeoromitxí (Jabutí). Belém: Museu Paraense Emílio Goeldi.

1995. Livro de Escrita em Djeoromitxí (Jabutí). Belém: Museu Paraense Emílio Goeldi.

Popovich, A. Harold, And Frances B. Popovich. 2005. Dicionário Maxakalí-Português. Cuiabá: Sociedade Internacional de Lingüística. 〈http:// www.sil.org/americas/brasil/PUBLCNS/DICTGRAM/MXDicPT.pdf〉. 
Pulleyblank, Douglas. 1989. Patterns of feature cooccurrence: The case of nasality. Arizona Phonology Conference 2, Coyote Papers 9:98-115.

Reis Silva, Maria Amélia. 2001. Pronomes, ordem e ergatividade em Mẽbengokré (Kayapó). M.A. thesis, Universidade Estadual de Campinas. Ribeiro, EduARdo Rivail. 2002a. O marcador de posse alienável em Karirí: Um morfema Macro-Jê revisitado. Línguas Indígenas da América do Sul (LIAMES), 2:31-48.

2002b. Directionality in vowel harmony: The case of Karaja. Proceedings of the Berkeley Linguistics Society 28:475-85.

2004a. Prefixos relacionais em Jê e Karajá: Um estudo históricocomparativo. Línguas Indígenas da América do Sul (LIAMES) 4:91-101. $2004 b$. Uma hipótese sobre a origem do padrão ergativo em algumas línguas Jê setentrionais. Ms. (5 pages), University of Chicago.

2005. Ofayé, língua Macro-Jê: Evidências adicionais. Paper presented at the Colóquios Lingüísticos do Museu Antropológico (Goiânia, Goiás, Brazil).

2006. Macro-Jê. Encyclopedia of Language and Linguistics, 2nd ed., ed. Keith Brown, vol. 7, pp. 422-26. Oxford: Elsevier.

2007. Eastern Macro-Jê: A hypothesis on the internal classification of the Macro-Jê stock. Ms.

2008. Preserved in amber: On the origins of a non-concatenative morphological pattern in Karajá. Paper presented at the annual meeting of the Society for the Study of the Indigenous Languages of the Americas, Chicago.

Forthcoming. A reconstruction of Proto-Jê (and its consequences for the Macro-Jê hypothesis).

Ribeiro, Michela Araújo. 2008. Dicionário Djeoromitxi-Português: Registro da diversidade lingüística do povo Jabuti. M.A. thesis, Universidade de Rondônia. 〈http://etnolinguistica.wdfiles.com/local—files/tese:ribeiro2008a/ribeiro_2008a.pdf $>$.

Ribeiro, Rosa Maria De Lima. 2008. Dicionário Arikapu/Português: Registro de uma língua indígena amazônica. M.A. thesis, Universidade de Rondônia. 〈http://etnolinguistica.wdfiles.com/local—files/tese:ribeiro2008/ribeiro_2008.pdf $>$.

$\rightarrow$ Rivet, Paul. 1953. La langue Mašubi. Journal de la Société des Américanistes, n.s., 42:119-25.

Rodrigues, Aryon Dall'Igna. 1964. A classificação do tronco linguístico Tupi. Revista de Antropología 12:99-104.

1980. Tupi-Guarani e Mundurukú: Evidências lexicais e fonológicas de parentesco genético. Estudos Linguísticos III, pp. 194-209. São Paulo: Unicamp.

1985. Evidence for Tupi-Carib relationships. South American Indian Languages: Retrospect and Prospect, ed. Harriet E. Manelis Klein and Louisa R. Stark, pp. 371-404. Austin: University of Texas Press. 
1986. Línguas Brasileiras: Para o Conhecimento das Línguas Indígenas. São Paulo: Edições Loyola.

1990. A case of grammatical affinity among Tupi, Karib, and MacroJê. Ms., Universidade de Brasília.

1992. Um marcador Macro-Jê de posse alienável. Anais da $44^{\mathrm{a}}$ Reunião Anual da Sociedade Brasileira para o Progresso da Ciência, p. 386. São Paulo.

1994. Grammatical affinity among Tupí, Karíb, and Macro-Jê. Ms., Universidade de Brasília.

1995. Glottalized stops in Proto-Tupi. Paper presented at the summer meeting of the Society for the Study of the Indigenous Languages of the Americas, University of New Mexico, Albuquerque.

1999. Macro-Jê. The Amazonian Languages, ed. R. M. W. Dixon and Alexandra Y. Aikhenvald, pp. 165-206. Cambridge: Cambridge University Press.

2000. “Ge-Pano-Carib” x "Jê-Tupí-Karib”: Sobre relaciones lingüísticas en Sudamerica. Actas del I Congreso de Lenguas Indígenas de Sudamérica, vol. 1, ed. Luis Miranda, pp. 95-104. Lima: Universidad Ricardo Palma. 2001. Flexão relacional no tronco lingüístico Macro-Jê. Boletim da Associação Brasileira de Lingüística (ABRALIN) 25:219-31.

2002. Para o estudo histórico-comparativo das línguas Jê. Línguas

Jê: Estudos Vários, ed. Ludoviko dos Santos and Ismael Pontes, pp. 1-14. Londrina: Universidade Estadual Londrina.

Rodrigues, Aryon D.; Ana Suelly C. Cabral; and luciana Dourado. 2005. Reconstrução do sistema de alinhamento Proto-Jê. Paper presented at $4^{\circ}$ Macro-Jê (Encontro de Pesquisadores de Línguas Jê e Macro-Jê). Recife: Universidade Federal de Pernambuco.

Salanova, Andrés P. 2006. The sense of Mẽbengokré nominalizations. Proceedings of the Eleventh Workshop on the Structure and Constituency in the Languages of the Americas, ed. A. Fuji and M. A. Reis Silva, UBC Working Papers in Linguistics. Vancouver: UBC Press.

2007a. The building blocks of aspectual interpretation. Paper presented at SULA 4: The Semantics of Under-Represented Languages in the Americas, University of São Paulo.

2007b. Nominalization and aspect. Ph.D. dissertation, Massachusetts Institute of Technology.

Santana, Áurea Cavalcante. 2006. Comparações preliminares entre a língua Chiquitano (Brasil/Bolívia) e o Proto-Jê. Paper presented at the Symposium "Advances in Native South American Historical Linguistics" at the Fifty-second International Congress of Americanists, Seville.

SAntos, LudoviKo C. 1997. Descrição de aspectos morfossintáticos da língua Suyá (Kisêdjê), família Jê. Ph.D. dissertation, Universidade Federal de Santa Catarina. 
1999. Verbos de forma larga y de forma corta em "Suyá." Actas I del VI Simpósio Internacional de Comunicación Social. Santiago de Cuba: Editorial Oriente.

2000. Aspectos do sistema de marcação de caso da língua Suyá. Actas I Congreso de lenguas indígenas de Sudamérica, vol. 1, ed. Luis Miranda, pp. 341-49. Lima: Universidad Ricardo Palma.

Santos, Ludoviko dos, And Ismael Pontes, eds. 2002. Línguas Jê: Estudos Vários. Londrina: Editora UEL.

Schourup, LAwrence C. 1973. A cross-linguistic study of vowel nasalization. Ohio State University Working Papers in Linguistics 15:190-221.

SeKelj, Tibor . 1950. Donde la civilizacion termina: Vida de las tribus del Amazonas. Buenos Aires: Editorial Albatros.

SeKI, Lucy. 2000. Gramatica do Kamaiurá: Língua Tupi-Guarani do Alto Xingu. Campinas: Unicamp.

2002. Krenak (Botocudo/Borum) e as línguas Jê. Línguas Jê: Estudos Vários, ed. Ludoviko dos Santos and Ismael Pontes, pp. 15-40. Londrina: Universidade Estadual Londrina.

SHAFER, Robert. 1963. Vergleichende Phonetik der karaibischen Sprachen. Verhandelingen der Koninklijke Nederlandse Akademie van Wetenschappen, Letterkunde, n.s., 69, no. 2. Amsterdam: N. V. Noord-Hollandsche Uitgeversmaatschappij.

Silva, LÉIA DE JESUS. 2005. Aspectos da fonologia e a morfologia da língua Rikbáktsa. M.A. thesis, Universidade de Brasília.

Silva Julião, Maria R. 2005. Aspects morphosyntaxiques de l'Anambe. Ph.D. dissertation, L'Universite de Toulouse-Le Mirail.

Silva Neto, Ambrósio Pereira DA. 2007. Revisão da classificação da família lingüística Puri. M.A. thesis, Universidade de Brasília.

Silverstein, MichAel. 1976. Hierarchy of features and ergativity. Grammatical Categories in Australian Languages, ed. R. M. W. Dixon, pp. 11371. Canberra: Australian Institute of Aboriginal Studies.

Snethlage, Emil Heinrich. 1937. Atiko Y: Meine Erlebnisse bei den Indianern des Guaporé. Berlin: Klinkhardt \& Biermann Verlag.

1939. Musikinstrumente der Indianer des Guaporégebietes. BaesslerArchiv, Beiträge zur Völkerkunde, vol. 10. Berlin: Dietrich Reimer and Andrews \& Steiner.

n.d. Vokabular von zwölf Sprachen aus dem Gebiete des Guaporé. Ms., Aachen.

Snethlage, Rotger Michael. 2002. Life, expeditions, collections and unpublished field notes of Dr. Emil Heinrich Snethlage. Current Studies on South American Languages: Indigenous Languages of Latin America (ILLA), vol. 3, ed. Mily Crevels et al., pp. 89-102. Leiden: Research School of Asian, African, and Amerindian Studies (CNWS). 
SouzA, Sueli M. 1998. A sintaxe de uma língua de verbo no final: Krahô.

Ph.D. dissertation, Universidade de São Paulo.

Storto, LuCiana. 1999. Aspects of a Karitiana grammar. Ph.D. dissertation, Massachusetts Institute of Technology.

Stout, Mickey and Ruth Thomson. 1974. Modalidade em Kayapó. Série Lingüística, vol. 3, pp. 69-97. Brasília: Summer Institute of Linguistics.

Tavares, Petronila da Silva. 2005. A grammar of Wayana. Ph.D. dissertation, Rice University.

Tremaine, Sheila. 2007. Dicionário Rikbaktsa-Português PortuguêsRikbaktsa. Cuiabá: Sociedade Internacional de Lingüística. 〈http://www. sil.org/americas/brasil/PUBLCNS/DICTGRAM/RKDic.pdf $\rangle$.

URBAN, GREG. 1985. Ergativity and accusativity in Shokleng (Gê). IJAL 51:164-87.

1998 [1992]. A história da cultura brasileira segundo as línguas nativas. História dos Índios no Brasil, 2nd ed., ed. Manuela Carneiro da Cunha, pp. 87-102. São Paulo: Companhia das Letras.

VOORT, HEIN VAN DER. 2005. Kwaza in a comparative perspective. IJAL 71:365-412.

2007. Proto-Jabutí: Um primeiro passo na reconstrução da língua ancestral dos Arikapú e Djeoromitxí. Boletim do Museu Paraense Emílio Goeldi, Ciências Humanas 2, no. 2:133-68. 〈http://www.museu-goeldi. br/editora/bh/artigos/chv2n2_2007/Proto(voort).pdf〉 or 〈http://www. scielo.br/bgoeldi $>$.

Forthcoming $a$. Caspar was right: Mashubi is Arikapú.

Forthcoming $b$. The Arikapú language: Grammatical sketch and dictionary.

WALKER, RACHEL. 1998. Nasalization, neutral segments, and opacity effects. Ph.D. dissertation, University of California, Santa Cruz.

Wiesemann, Ursula. 1978. Os dialetos da língua Kaingáng e o Xokléng. Arquivos de Anatomia e Antropologia 3:199-217. Rio de Janeiro: Instituto de Antropologia Prof. Souza Marques.

2002. Dicionário bilíngüe Kaingang-Português. Curitiba: Editora Evangélica Esperança. 〈http://www.sil.org/americas/brasil/PUBLCNS/DICTGRAM/KGDict.pdf .

WiLLIAMS, JAMES. 1932. Grammar Notes and Vocabulary of the Language of the Makuchi Indians of Guiana. St. Gabriel-Mödling: Verlag der Internationalen Zeitschrift Anthropos. 